\title{
Consensus Gained, Consensus Maintained? Changing New Zealand's Electoral Law $1927-2007$
}

\author{
A Thesis \\ Submitted to Victoria University of Wellington \\ In Fulfilment of the Requirements for the Degree of \\ Master of Arts in Political Science
}

James Christmas 
To $J M C$ 


\section{Acknowledgments}

In submitting this work, I acknowledge a substantial debt of gratitude to my supervisor, Professor Elizabeth McLeay, for her guidance, constant attention and interest.

For their encouragement, I thank my parents. For his patience, this thesis is dedicated to James.

James Christmas

Christchurch 2010 


\section{Contents}

$\begin{array}{ll}\text { Abstract } & 5\end{array}$

List of Tables and

Figures

Chapter One

Introduction

Chapter Two

The Electoral Law in Context

Chapter Three

Milestones: Three Eras of Electoral Amendment?

Chapter Four

Parliament and Electoral Rules

Chapter Five

Boundaries, Franchise and Registration

Chapter Six

Election Administration and Electioneering

92

Chapter Seven

Assessing Trends and Motivations

112

Chapter Eight

Conclusion

132

Appendix A

Acts Affecting the Electoral Law 1927 - 2007

135 (in chronological order)

Appendix B

Unsuccessful Electoral Reform Bills, 1927 2007 (in chronological order)

Bibliography 


\section{Abstract}

In the eighty years between the passage of New Zealand's first unified Electoral Act in 1927, and the passage of the Electoral Finance Act 2007, the New Zealand Parliament passed 66 acts that altered or amended New Zealand's electoral law.

One central assumption of theories of electoral change is that those in power only change electoral rules strategically, in order to protect their self-interest. ${ }^{1}$ This thesis is an investigation into the way New Zealand governments effect and have effected their desired changes to the electoral law through the legislative process, and the roles self-interest and the active search for consensus between political parties have played in that process.

It argues that, while self-interest serves as a compelling explanation for a great deal of electoral law change in New Zealand, altruistic motivations and the development of parliamentary processes influenced behaviour to an equal, and perhaps even greater, extent.

${ }^{1}$ Shaun Bowler, Todd Donovan and Jeffrey Karp, 'Why Politicians Like Electoral Institutions: SelfInterest, Values or Ideology?', The Journal of Politics, Vol. 68, No. 2, May 2006, p. 434. 


\section{List of Tables and Figures}

Table 1

Table 2

Table 3

Table 4

Table 5

Table 6

Table 7

Table 8

Table 9

Table 10

Table 11

Table 12
Effect of Electoral Amendment Legislation

Subject Area of Electoral Amendment

Legislation

Level of Contention over Electoral

Amendment Legislation

Outcome of Electoral Amendment Legislation

Class of Electoral Amendment Legislation

Electoral and Electoral Amendment acts

passed by National or National-led and Labour or Labour-led Governments 1927-2007

Electoral Law Changes introduced by National

or National-led and Labour or Labour-led

Governments 1927 - 2008 by Subject

Contention v Outcome of Electoral and

Electoral Amendment acts passed under

National or National-led and Labour or

Labour-led Governments 1927-2007

Contention v Category of Electoral and Electoral Amendment acts passed under National or National-led and Labour or Labour-led Governments 1927-2007

Outcome v Category of Electoral and Electoral Amendment acts passed under National or National-led and Labour or Labour-led Governments 1927-2007

Contention v Class of Electoral and Electoral

Amendment acts passed under National or

National-led and Labour or Labour-led

Governments 1927-2007

Outcome v Class of Electoral and Electoral

National-led and Labour or Labour-led

Governments 1927-2007 


\section{Chapter One Introduction}

In the eighty years between the passage of New Zealand's first unified Electoral Act in $1927,{ }^{2}$ and the passage of the controversial Electoral Finance Act 2007, the New Zealand Parliament passed 66 acts that, to varying extents and to varying ends, altered or added to the electoral law. These changes ranged from one-word technical amendments correcting a drafting error to the extension of the franchise to 18 year olds; from the prolongation of the parliamentary term during World War II to the introduction of computer technology in organising the electoral rolls; and from the regulation of election broadcasting to the change from First Past the Post (FPP) to the Mixed Member Proportional (MMP) voting system. Not one area of New Zealand's electoral law remained unamended over the period.

This thesis is an investigation into the way in which New Zealand governments and politicians effect their desired changes to the electoral law through the legislative process and the roles self-interest and the active search for consensus between political parties has played in that process. One central assumption of theories of electoral change is that those in power only change rules strategically, in order to protect their self-interest. ${ }^{3}$ I argue that, while self-interest serves as a compelling explanation for a great deal of electoral law change in New Zealand, altruistic motivations and the development of parliamentary processes and conventions have influenced behaviour to at least an equal extent.

\footnotetext{
${ }^{2}$ Until 1927, electoral law was contained in the various Electoral acts, Electoral Amendment acts, the Legislature Act 1908 and in various Legislature Amendment acts.

${ }^{3}$ Bowler, Donovan \& Karp, 'Why Politicians Like Electoral Institutions: Self-Interest, Values or Ideology?', p. 434.
} 
The motivations behind the passing of each of the 66 amendment acts and the ways in which governments and parliaments went about the task are numerous. Some acts amended one area of the electoral law, while others served as omnibus acts amending multiple areas. Several acts were passed by Parliament in a single day under urgency, while the debates over others stretched into weeks of contentious parliamentary sittings. Some acts were arguably self-interested moves by governments seeking to enhance their own prospects of re-election or disadvantage their opponents. Other acts were the product of non-partisan select committees or governments that have sought consensus with the opposition to create durable and non-partisan legislation.

The argument that changes to the electoral law should ultimately be consensual was raised by politicians from both of New Zealand's major parties - National and Labour - throughout the period studied. The last act I consider, the highly contested Electoral Finance Act 2007, brought to the fore the argument that the alteration of the electoral law in New Zealand should ideally be carried out in a non-partisan fashion with consensus between government and opposition. It was expressed by both major parties in relation to the Electoral Finance Act. National Party Member of Parliament, Dr Wayne Mapp, argued during the debate that, "[i]n the past, this country has always created its electoral law on a consensus basis, but that did not serve the purposes of the Government this time, because it knows perfectly well that it wants its own law to suit its own purposes." 4 The argument was also expressed after the 2008 General Election by Labour Party leader, Phil Goff, who said "I don't think the way the Electoral Finance Act was passed or necessarily its specific detail was as good as it

\footnotetext{
${ }^{4} 644$ NZPD 13532, 5 December 2007.
} 
could have been ... Any matter that's constitutional or electoral, we should be seeking consensus for. We didn't have that consensus.",

It is important to define 'consensus' at the outset. The word can describe a process or an outcome. A consensual or co-operative legislative process does not automatically lead to an outcome of consensus and, more rarely, a unanimous outcome may arise from a contentious, non-consensual process. To make clear this distinction, where this thesis considers consensus, it considers outcome. It considers process in terms of contention or lack of contention. The role of consensus in changing the electoral law is an interesting area of investigation, especially because, in New Zealand, the convention of consensus that has arisen in the area of the electoral law stands apart from an otherwise adversarial legislative process. New Zealand has an adversarial legislative process and is, by its nature, a politically combative institution. Many of the procedures of the House are designed specifically to enable the House to scrutinise and control the government. ${ }^{6}$ As David McGee outlines, "everything the House does potentially gives it the opportunity to probe and criticise the actions of the Government." 7 This thesis finds that, overall, electoral amendment legislation provides no exception to the general adversarial nature of Parliament, although there are notable specific examples of areas where the House has worked together.

As examined in Chapter Two, the electoral law forms part of the New Zealand constitution. Yet an exploration of the electoral law at a purely constitutional level is not the aim of this thesis. Its focus, rather, are the conventions, processes and

\footnotetext{
${ }^{5}$ Claire Trevett, New Zealand Herald, "Goff Admits Mistakes Over Electoral Law”, 13 November 2008.

${ }^{6}$ David McGee, Parliamentary Practice in New Zealand, $3^{\text {nd }}$ ed., Dunmore Press, Wellington, 2005, p. 4.

${ }^{7}$ Ibid.
} 
motivations that characterised change in the electoral law over the eighty year period studied. The amendment and alteration of the electoral law is an area that deserves special attention. As Alan Robinson argued in 1970:

Since electoral rules can have a major influence on the fortunes of the various contenders for political office, it is not uncommon in democratic countries for electoral reforms to be the subject of intense party controversy. New Zealand has been no exception. ${ }^{8}$

Because a government's electoral prospects can be directly affected by the amendments it makes to electoral legislation, there is arguably no area of legislative activity that provides as great an opportunity to study the interaction of self-interest and bi-partisanship, of ideology and pragmatism, and of party and principle in New Zealand politics.

With a significant amount of legislation pertaining to electoral matters passed over the past eighty years studied (66 acts), it is important to define at the outset what the term 'electoral law' entails. The term is often narrowly defined. In his seminal work on the political consequences of electoral laws, D.W. Rae defines electoral law the following way: ${ }^{9}$

Electoral laws are those which govern the processes by which electoral preferences are articulated as votes and by which these votes are translated into distributions of governmental authority (typically parliamentary seats) among the competing political parties.

In order to avoid any oversight and to provide the fullest picture possible of the process of electoral law amendment in New Zealand, this thesis takes a wider approach in defining which legislation falls into the category of 'electoral law' and its

\footnotetext{
8 Alan Robinson, 'Parliament in New Zealand', in The Reform of Parliament, John Marshall (ed.), New Zealand Institute of Public Administration, Wellington 1978, p. 142.

${ }^{9}$ D.W. Rae, The Political Consequences of Electoral Laws, Yale University Press, New Haven, 1967, p. 14
} 
reform. As a result, Rae's definition forms only one part of the definition adopted in this paper. My definition includes the legislation that determines how a vote translates into the election of a representative (Rae's definition), but also the laws governing electoral processes and regulations. Indeed, it is in this latter category that the most interesting case studies of consensus politics (and the opposite) occur. Accordingly, the definition adopted for the purposes of the following analysis includes not only the laws that govern the way in which a vote is transferred to a result but, for example, the laws that surround the election campaigns, election broadcasting, the rules that govern the franchise, or the eligibility of an elector to vote or to sit (or remain sitting) in Parliament. Overall, the focus of the investigation is process rather than outcome. Of course, the content of each electoral amendment act and its political outcome (intended or otherwise) forms an integral part of the following analysis, but only so far as it can assist in understanding the reasons behind the passing of each act and the process by which it was passed.

1927 serves as a useful starting point for several reasons. First, New Zealand's first Electoral Act was passed in 1927. Before 1927, New Zealand electoral law was spread over a number of different acts, the most important of which was the Legislature Act 1908. The 1927 Act amalgamated all existing electoral law and all subsequent electoral amendment legislation amended that Act until the passage of the Electoral Act 1956. Second, the Act preceded the emergence of the two-party system by only several years, ${ }^{10}$ and, during the period between 1927 and 1935, when the first Labour Government was elected, several highly controversial electoral amendments were passed under the Coalition Government and merit attention. Finally, there are

\footnotetext{
${ }^{10}$ The two-party system emerged after the election of the first Labour Government in 1935 and the formation of the National Party out of the old United and Reform parties in 1936.
} 
three Electoral acts in the period studied. Alongside the 1956 and 1993 Electoral acts, the Electoral Act 1927 serves as a useful point of reference when examining a period that spans just under a century.

The analysis is focussed solely on the electoral law passed by Parliament that affects Parliament itself. As a result, electoral acts passed by Parliament pertaining to local government are excluded. Also excluded are broader constitutional changes such as the 1947 Statute of Westminster, the 1950 abolition of the Legislative Council and the various acts pertaining to constitutional, but non-electoral, matters. In the cases where these acts overlap, such as in the Constitution Act 1986, the aspects of the act relating to the electoral law are included. A number of provisions in largely unrelated acts, which nonetheless amended or circumvented a piece of electoral legislation, are included. For example, several Finance acts in the late 1950s and early 1960s contained clauses exempting a Member of Parliament from disqualification under the Electoral Act for accepting honoraria. On several occasions discretion has been exercised and an Act that technically qualifies under the adopted definition of 'electoral law' has been excluded. For example, the Licensing Amendment Act 1961 contained a provision in its schedule that amended section 24(1) of the Electoral Act 1956. The provision related to the licensing district arrangements for the Chatham Islands, was incidental to the Electoral Act and the amendment removing it was of no importance and received no debate.

Hansard (the New Zealand parliamentary Debates or NZPD), the Journals of the House of Representatives (JHR) and Appendices to the Journals (AJHR) serve as major primary sources. In order to preserve a focus on process, Parliament and public argument, Hansard is the major source of information for chapters four to six, which 
examine the passage of various pieces of legislation through the House of Representatives. In these chapters, I have included secondary sources only where they clarify ambiguities or add substantially to the analysis. Due to the large period of time covered by the thesis and a need to provide equal coverage to a number of acts, formal interviews were not undertaken. The collation of every piece of electoral amendment legislation over an eighty year period was a substantial task. Several checks of the indexes of every volume of Hansard published since 1927 were undertaken to ensure no Act or Bill has been omitted. All collected information concerning electoral legislation and failed electoral bills is tabled in Appendices A and B in the hope other scholars may use the primary research as a base on which to undertake further study. Analysis was, on occasion, hampered by the fact the proceedings of committee stages were not recorded in Hansard until 1995 and that no record is made of select committee proceedings.

It remains to provide a structural overview of what is to follow. Chapter two provides an empirical and theoretical context to the thesis. It reviews relevant literature and places the thesis within the context of existing work in both areas. It also provides a background to the constitutional position of electoral law in New Zealand and the parliamentary processes used to change the electoral law. This section covers, among other things, the relevance of the select committee process to the amendment of the electoral law and the constitutional and conventional issues involved in the entrenchment of certain provisions of the electoral law. ${ }^{11}$ Chapter three sets out four legislative milestones in the eighty years studied and hypothesises the existence of three distinct 'eras' of electoral law change. Chapters four to six examine the history

\footnotetext{
${ }^{11}$ As discussed in chapter two, the reform of election law in New Zealand requires, on some issues, bipartisan consensus. The entrenched clauses of the Electoral Act 1993, and before it the Electoral Act 1956 , require 75 percent support to amend certain provisions.
} 
of successful and failed electoral law change from 1927 to 2007. They consider the nature of changes to the electoral law and the process by which these changes have progressed through Parliament. The chapters are organised by subject matter. Chapter four considers the law relating to parliament and government formation. Specifically, it considers the length of the parliamentary term, the number of Members of Parliament in the House, the qualifications to be a Member of Parliament, formation of a government and the electoral system. The focus of chapter five is electoral boundaries, franchise, voter registration and method of voting, while chapter six looks at the rules surrounding electioneering, broadcasting and other electoral administration. Emerging findings and trends are discussed throughout. Finally, chapter seven correlates and compares various aspects of changing the electoral law, including contention, outcome and subject matter. It examines the dual explanations of self-interest and the search for consensus in electoral reform. Chapter eight concludes and explores where further work may be done on the questions raised by this thesis. 


\section{Chapter Two The Electoral Law in Context}

Before embarking on any investigation of the process by which the electoral law has been changed over the past 80 years in New Zealand, it is necessary to provide appropriate context in which to place the analysis that follows. This chapter comprises two parts. Part one provides an empirical background to the constitutional position of the electoral law in New Zealand and the parliamentary processes involved in changing it. It considers relevant literature in its analysis. Part two provides an overview of theoretical propositions advanced by scholars about assessing motivations behind changing the electoral law.

\section{Electoral Law and Parliament}

Recent literature on the New Zealand electoral system falls into three general categories. The first category centres on electoral outcomes and the operation of electoral processes. This includes analysis provided in major legal, parliamentary and constitutional texts. The focus here is often on the constitutional position of the laws and regulations through which the New Zealand electoral process operates. Books in this category include Philip Joseph's Constitutional and Administrative Law in New Zealand, David McGee's Parliamentary Practice in New Zealand, ${ }^{12}$ and Geoffrey Palmer's Bridled Power. While Bridled Power and Constitutional and Administrative Law in New Zealand stand at present as the authoritative texts on New Zealand constitutional matters, the broad focus of these texts on the post-1993 era and on constitutional matters in general means any examination of the processes by which the electoral law is changed is very limited. While the Electoral Act 1956 and the entrenched provisions are discussed at length in Joseph as a topic of legal interest,

\footnotetext{
${ }^{12}$ McGee, Parliamentary Practice in New Zealand.
} 
both books are strongly weighted towards the MMP-era. New Zealand's current constitutional situation, and even aspects of its development, is often presented as something that simply happened. In these works, discussion about the constitutional intricacies of entrenchment precludes substantial discussion about the majority of provisions of the electoral law that are not entrenched. The focus of these works is a lofty constitutional one. The exceptions are older constitutional works, which provide, primarily now through their historical value, insight into the development of the electoral amendment process. Works such as K.J. Scott's seminal 1962 work, The New Zealand Constitution, which argued the Electoral Act 1956 was the New Zealand constitution, provide a helpful context. These works can add depth to analysis when contextual secondary sources are often thin on the ground.

The second category contains literature on electoral design and electoral outcomes. This literature often has a political science focus rather than a legal focus. Aside from Andrew Geddis' 2007 book, Electoral Law in New Zealand, which focussed solely on the electoral law while retaining a legalistic viewpoint, much of the recent literature in this category centres primarily on electoral system change and the move from FPP to MMP.

The third category contains empirical histories of the New Zealand electoral system. The primary academic focus of the second category of literature has been on electoral outcomes and electoral system design. This category includes the voluminous literature from the 1980s to the present concerning MMP and electoral reform. For the purposes of this thesis, this category has not been of great use. While the Electoral Act 1993 stands as one of the most important electoral acts in New Zealand history, it 
is one act analysed alongside 65 others in this paper. The focus of the second category is design; the focus of this thesis is process.

The third category of literature contains a smaller amount of material. Its focus is the legislative and governmental processes through which electoral reform has taken place. Into this category falls material such as the thoroughly useful Appendix to the report of the Royal Commission on the Electoral System 1986, which details the history of electoral amendments in some detail, ${ }^{13}$ and more recent books such as Atkinson's History of the Vote in New Zealand. In this literature, process receives somewhat more attention than it receives in the other categories. Overall, however, parliamentary process is eschewed in favour of a primarily outcome-focussed analysis. Owing, perhaps, to a lack of scholarly attention to the topic, no major academic disputes exist between authors about the development of New Zealand's electoral law. If consensus does not always exist among political parties on changes to the electoral law, broad consensus exists among academics on the place of the electoral law in New Zealand.

While the definition of the words 'New Zealand constitution' has been substantially broadened in recent years, it has always been widely acknowledged by modern constitutional scholars that the electoral law forms an important part of the New Zealand constitution. Like the United Kingdom, New Zealand does not have a single document which acts as a written constitution. Instead, the New Zealand constitution is found across legislation, practice and convention. ${ }^{14}$ Dicey defines a constitution as

\footnotetext{
${ }^{13}$ B. Ritchie, \& H. Hoffman, "The Electoral Law of New Zealand, A Brief History", Towards a Better Democracy: Report of the Royal Commission on the Electoral System, Appendix A, Wellington, 1986; and K. Sorrenson, "A History of Maori Representation in Parliament", Towards a Better Democracy: Report of the Royal Commission on the Electoral System, Appendix B, Wellington, 1986.

${ }^{14}$ Geoffrey Palmer, Bridled Power, Oxford University Press, Auckland, 2004, p. 5.
} 
"all rules which directly or indirectly affect the distribution of the exercise of the sovereign power in the state." ${ }^{15}$ Geoffrey Palmer provides a more recent definition in Bridled Power when he says a constitution is "the system or body of fundamental principles under which a nation is constituted or governed... It is a set of rules structures and procedures." 16 The electoral law is an essential part of either definition. Indeed, its role in the New Zealand constitution has been recognised for many decades. In his 1962 work on the New Zealand constitution, K.J. Scott argues that the constitutional importance of the Electoral Act means that, in the absence of a written constitution, it can be regarded as part of New Zealand's 'constitution'. ${ }^{17}$ However, while the electoral law may hold a special place in New Zealand's constitutional framework, it does not, strictly speaking, stand apart from other statutes.

Whereas many of the respective electoral laws of the United States and Australia are contained in a federal constitution, the New Zealand electoral law is more flexible and can be amended through Parliament's ordinary legislative processes. Arguably, the only other Western country whose constitutional law is so flexible is the United Kingdom. ${ }^{18}$ D.W. Rae argues electoral law may be defined per genus et differentiam against other laws. ${ }^{19}$ This is not wholly accurate in the case of New Zealand.

There is, however, one notable exception to this conclusion. In New Zealand, the entrenchment of several key provisions of the electoral law emphasises the important constitutional status of the electoral law and provides somewhat less flexibility than exists in the system closest to New Zealand's - that of the United Kingdom.

15 A.V. Dicey, Introduction to the Study of the Law of the Constitution, $8^{\text {th }}$ ed., Liberty Fund, Indianapolis, 1982, p. cxl.

${ }^{16}$ Palmer, Bridled Power, , p. 4.

${ }^{17}$ K.J. Scott, The New Zealand Constitution, Oxford University Press, Oxford, 1962, p. 6.

${ }^{18}$ Ibid., p. 20.

${ }^{19}$ Rae, The Political Consequences of Electoral Laws, p. 14. 
Originally enacted in the Electoral Act 1956, and re-utilised in the Electoral Act 1993, the entrenched provisions of New Zealand's electoral law set it somewhat apart from other statutes by requiring a $75 \%$ majority of the House to amend certain provisions. With the exception of these entrenched provisions, Parliament amends, alters, or otherwise adds to the electoral law in the same way as any other legislation, by a simple majority - 50 percent of the House plus one. ${ }^{20}$ In the New Zealand House of Representatives, under normal circumstances, bills pass through an introduction and first reading before being considered by a select committee. On their return to the House they receive a second reading, consideration by committee of the whole House and a third reading, after which time, if passed, they receive the Royal Assent. ${ }^{21}$ All bills must have three readings before they are passed. ${ }^{22}$

In 1956, entrenchment was at the time a constitutional novelty, apparently advocated within Cabinet by John Marshall, who was at the time Minister of Justice. ${ }^{23}$ The clause that entrenched several clauses in the Electoral acts 1956 and 1993 required the support of $75 \%$ of the House or a simple majority in a national referendum in order for those entrenched clauses to be altered. In doing so, the clause prevented a majority government (as all governments invariably were under FPP) from unilaterally amending or repealing certain parts of the electoral law. The entrenched provisions, however, were limited. Only six clauses were entrenched in the 1956 Act:

- Section 12 relating to the duration of the House

\footnotetext{
${ }^{20}$ Speakers' Rulings provide that the 75 percent vote on a reserved provision is required at the point at which the relevant clause is being considered in the committee of the whole house. A 75 percent vote is not required at any other stage of debate on the bill. See 433 NZPD 3513.

${ }^{21}$ McGee, Parliamentary Practice in New Zealand, p. 341.

${ }^{22}$ Standing Order 269(1).

${ }^{23}$ John Marshall in The Reform of Parliament, John Marshall (ed.), New Zealand Institute of Public Administration, Wellington 1978, p. 10.
} 
- Section 15 relating to the Representation Commission

- Section 16 and the definition of the term "European Population" relating to the division of New Zealand into European electorates after each census

- Section 17 relating to the allowance for the adjustment of the quota.

- Section 39(1) and the definition of the term "adult" in 39(2)(1), so far as those provisions prescribe 21 years as the minimum age for persons qualified to be registered as electors or to vote.

- Section 106 relating to the method of voting.

Furthermore, the provision that enabled entrenchment was not entrenched itself. In other words, it was not 'doubly entrenched'. In 1956 this was considered by some as an omission or drafting error but it eventually became clear that single entrenchment was deliberate. ${ }^{24}$ K.J. Scott, who interviewed members of the Electoral Law Committee in 1956, revealed the Holland Government decided to leave this loop-hole in the Act to avoid the extension of the power of the judiciary in the case an amendment was made to an entrenched provision without the requisite authority provided by the terms of the entrenchment requirement. ${ }^{25}$ Any fears held by scholars and politicians in the 1950s that the entrenched provisions may eventually be undone by a simple majority proved unfounded by $2007 .^{26}$ As shown in chapters three to seven, if there is one concrete rule that can be found in the history of New Zealand's electoral law since the 1950s, it is that no government has ever attempted to circumvent the entrenchment clauses. In New Zealand, parliamentary or Cabinet

\footnotetext{
${ }^{24}$ Scott, The New Zealand Constitution, p. 7.

${ }^{25}$ Ibid.

${ }^{26}$ As Philip Joseph points out, however, the legal situation in 2009 is markedly different to that in the 1950s. Indeed, there is an opinion among many constitutional scholars that the courts could potentially strike down an amendment to the entrenched provisions passed by a simple majority of Parliament. See Philip Joseph, Constitutional and Administrative Law in New Zealand, $3^{\text {rd }}$ ed., Thomson Brookers, Wellington, 2007
} 
process can often form part of a constitutional convention. As will be shown, there is a strong argument that 60 years of observation by governments of the entrenched provisions of the electoral law mean that that observation has become a convention.

Before moving to the theoretical component of this chapter, it is necessary to provide a background to the increasing role of select committees, and particularly the electoral committee, in the New Zealand parliamentary process over the years. As covered in chapters four to seven, select committees played a major role, especially in the second half of the period studied, in the reform of New Zealand's electoral law.

Much of the intensive work of the House occurs in select committees. ${ }^{27}$ Their duty is to carry out work on behalf of the House and to communicate their conclusions to the House in the form of reports. ${ }^{28}$ Standing Orders mandate the automatic establishment of a number of select committees at the beginning of each Parliament. ${ }^{29}$ In addition to these committees, the House is able to set up "ad hoc" committees for specific purposes. ${ }^{30}$ From 1981, electoral matters were always considered by a select committee. Between 1981 and 1999 an ad hoc Electoral Law Committee was established in each Parliament. ${ }^{31}$ From 1999, electoral matters were considered by the Justice and Electoral Select Committee, automatically established at the beginning of a new Parliament.

Electoral Law Committees existed in New Zealand, however, since the creation of the Electoral Act Committee to consider the Electoral Bill 1956. These committees

\footnotetext{
${ }^{27}$ McGee, Parliamentary Practice in New Zealand, p. 236.

${ }^{28}$ Ibid.

${ }^{29}$ Standing Order 185(1),(2).

${ }^{30}$ Standing Order 185(1),(2).

${ }^{31}$ McGee, Parliamentary Practice in New Zealand, p. 8.
} 
stand apart from other committees, automatic or ad hoc, in that many were created to consider a bill before introduction. Rather than consider legislation introduced by a government, select committees were at times actively involved in making recommendations to governments for legislative implementation. As covered in following chapters, the two most significant examples of select committees that operated in this manner were the 1973 Electoral Act Committee and the 1979 Select Committee on the Electoral Law. The 1973 Committee, set up to "consider possible amendments to the Electoral Act 1956", consisted of three high-ranked members from both major parties, including their leaders. ${ }^{32}$ It produced two reports, an interim report in 1974 which unanimously recommended the voting age be reduced to 18 - a recommendation then introduced in legislation by the government - and a final report, some of whose more controversial recommendations were implemented in the Electoral Amendment Act 1975.

The 1979 Select Committee on the Electoral Law was appointed by Parliament in August 1979 against a background of concerns about the operation of the law governing general elections, which had come to a head during the 1978 General Election. ${ }^{33}$ The Committee was charged with examining the findings of a committee of inquiry into the administration of the Electoral Act and the Supreme Court's report to Parliament about the Hunua electoral petition, and to develop legislative and administrative improvements relevant to both areas. ${ }^{34}$ The Committee was reappointed on three occasions to "consider fully certain longer term substantive issues and other matters which had emerged in the course of its investigations." ${ }^{35}$ After that,

\footnotetext{
${ }^{32}$ Neil Atkinson, Adventures in Democracy, University of Otago Press, Dunedin, 2003, p. 186.

${ }^{33}$ First Report of the Select Committee on the Electoral Law [1980] V AJHR I 17.

${ }^{34}$ Ibid.

${ }^{35}$ Third Report of the Select Committee on the Electoral Law 1983 [1983] VII AJHR I 17.
} 
the establishment of an ad hoc electoral committee became standard until Standing Orders established a permanent Justice and Electoral Committee in 1999.

\section{Theoretical Literature}

An important aspect of examining consensus and contention in the context of the New Zealand electoral law is motivation. What makes parties and Members of Parliament behave in either a partisan or non-partisan manner on the amendment of the law? As chapters three to seven show, the New Zealand experience presents numerous examples of both types of behaviour. With the empirical background in place, it is necessary to provide a theoretical context for the analysis. One central assumption of theories of electoral change is that those in power only change rules strategically, in order to protect their self-interest. ${ }^{36}$ This thesis argues that, while selfinterest serves as a compelling explanation for a great deal of electoral law change in New Zealand, altruistic motivations and the development of parliamentary processes and conventions have influenced behaviour to an equal, and perhaps even greater, extent. Much of the theoretical material about self-interest in politics concentrates on electoral system change. Often, electoral system analyses use the word 'electoral' to refer to electoral system change. A typical example of this is Dunleavy and Margetts' conclusion that change in election rules is a relatively rare event in established democracies. ${ }^{37}$ As is shown in chapters three to six, however, change to New Zealand election rules in the period studied was frequent. Indeed, electoral system change, while perhaps the most important change, formed but one part of electoral law change in New Zealand.

\footnotetext{
${ }^{36}$ Bowler, Donovan \& Karp, 'Why Politicians Like Electoral Institutions: Self-Interest, Values or Ideology?', p. 434.

37 Patrick Dunleavy and Helen Margetts, "Understanding the Dynamics of Electoral Reform", International Political Science Review, 16 (1), 1995, pp. 9-29.
} 
Generally, literature on self-interest can be divided into two categories: the literature arguing that self interest forms a major factor in electoral law change and the literature arguing it does not. The central assumption of the first category is that those in power only change rules strategically, in order to protect their self-interest. ${ }^{38}$ Boix argues that "[a]nticipating the coordinating consequences of electoral rules, any current government (provided it has the monopoly over electoral rulemaking) shapes the electoral rules to its advantage." 39 Benoit is less equivocal than Boix in his conclusion, but identifies a number of possible explanations for political parties' preferences for electoral design. ${ }^{40}$ Two of the most important are office-seeking and personal gain. In the first category, parties seek to implement changes to the electoral law in order to maximise the chance of a successful election result. As Benoit outlines: ${ }^{41}$

The office-seeking model... posits both direct and indirect utility from holding office. Direct utility might be partisan power or representation of one's own constituency; indirect utility might be gains from additional shares of allocative resources determined by the balance of legislative seats, including (but not limited to) policy.

The second category outlines the influence of individuals on the electoral amendment process. Benoit states: $:^{42}$

A personal gain model might explain parties' preferences for electoral alternatives based on the expected personal gains for key individuals associated with the alternatives. Party leaders may favor a particular electoral alternative in order to maximize their personal power.

He concedes the personal gain explanation raises questions as to whether parties are behaving as unitary actors. This thesis does not delve into the theoretical detail on this

\footnotetext{
${ }^{38}$ Bowler, Donovan \& Karp, 'Why Politicians Like Electoral Institutions: Self-Interest, Values or Ideology?', p. 434.

${ }^{39}$ Charles Boix, 'Setting the Rules of the Game: The Choice of Electoral Systems in Advanced Democracies', American Political Science Review 93 (3), 1999, p. 609.

${ }^{40}$ Kenneth Benoit, 'Models of Electoral System Change', Electoral Studies 23 (3), 2004, p. 368.

${ }^{41}$ Ibid.

${ }^{42}$ Ibid.
} 
point. It assumes that parties behave as unitary actors, but that individual actors wield differing levels of influence within the larger, party unit. At the other end of the spectrum, other academics argue uncertainty in outcome precludes self-interest from serving as a major factor in decisions surrounding electoral reform. Andrews and Jackman argue that, while party leaders attempt to behave strategically, it is not clear how they can do so effectively when they are faced with uncertainty about outcomes. ${ }^{43}$ There is also an argument for something of a middle ground. Bowler, Donovan and Karp conclude that rational self-interest is a major feature of parties' attitudes to electoral institutions, but that attitudes about democracy and political ideology also have a role to play. ${ }^{44}$ Benoit, too, posits an alternative to the pure selfinterest explanation: ${ }^{45}$

\begin{abstract}
Parties may also rank alternative institutions according to their preferences for institutional outcomes that affect the general, rather than partisan, interest. Just as the framers of the US constitution debated passionately over the merits of a federal versus a confederal design, parties may struggle to implement competing institutions on the basis of their different preferences for collective political outcomes. This may be a social concern such as fairness or representation, a concern with producing good Government, safeguards against hyperconcentration of power, and so on.
\end{abstract}

Chapters four to seven assess the history of change in New Zealand's electoral law against this theoretical background and find that a middle path is the best description. While it is often difficult and speculative to identify on which occasions self-interest has played a role, it is possible to infer through a wide lens that both self-interest and altruism have each played a role in electoral change in New Zealand. In light of the New Zealand example, both ends of the theoretical spectrum could be said to be lacking explanatory power.

\footnotetext{
43 Josephine Andrews and Robert Jackman, 'Strategic Fools: Electoral Rule Choice Under Extreme Uncertainty', Electoral Studies 24 (1), 2005, p. 82.

${ }^{44}$ Bowler, Donovan \& Karp, 'Why Politicians Like Electoral Institutions: Self-Interest, Values or Ideology?', p. 434.

${ }^{45}$ Kenneth Benoit, 'Models of Electoral System Change', Electoral Studies 23 (3), 2004, pp. 368-69.
} 
Chapter three now examines the 'big picture' of electoral law change between 1927 and 2007, and identifies several milestones around which analysis of the wider period can be based. 


\section{Chapter Three Milestones: Three Eras of Electoral Amendment?}

Between 1927 and 2007, the New Zealand Parliament passed 66 separate pieces of electoral or electoral amendment legislation. Under the two party and subsequent MMP system, ${ }^{46}$ Parliament enacted a similar amount of electoral legislation under National and National-led, and Labour and Labour-led, governments. To allow thorough analysis, each piece of legislation has been classified in each of a number of categories. ${ }^{47}$ All distinctions are made on the basis that a full analysis of amendments to the electoral law must take into account not only content, but process. The first concerns the effect of the Act on existing electoral legislation. Most Electoral Amendment acts passed between 1927 and 2007 altered existing legislation. Several acts, such as the Electoral Act 1927, amalgamated existing legislation. Other acts prevented the operation of existing legislation, such as the Finance Act 1960, which retrospectively prevented the disqualification of a Member of Parliament. Finally, some acts were substantially original, such as the Electoral Act 1956, which repealed the Electoral Act 1927 and introduced a large amount of new law.

Table 1 - Effect of Electoral Amendment Legislation

\begin{tabular}{|l|l|}
\hline Amalgamating & The Act amalgamates existing electoral legislation into a new statute. \\
\hline Amending & The Act primarily amends existing electoral legislation. \\
\hline Circumventing & The Act prevents operation of existing electoral legislation. \\
\hline Original & $\begin{array}{l}\text { The Act is wholly or substantially original in nature (may also amend } \\
\text { existing law). }\end{array}$ \\
\hline
\end{tabular}

\footnotetext{
46 The two-party system began with the election of the first Labour Government in 1935 and the amalgamation of the old United and Reform Parties into the National Party. While numerous third parties have entered the House of Representatives since the introduction of MMP in 1993, National and Labour continue to be the largest and most dominant political parties in New Zealand.

${ }^{47}$ A full chart is set out in Appendix A.
} 
Legislation is also categorised by subject area. This category is determined by the primary area or areas of electoral law affected by each individual Act. Due to the substantial volume of subject matter covered in some acts, grey areas exist around whether particular legislation falls, or does not fall, into a certain category. The rule in deciding whether a piece of legislation should be included in, or left out of, a category is the extent to which its inclusion will assist coherence and quality of analysis.

Table 2 - Subject Area of Electoral Amendment Legislation

\begin{tabular}{|c|c|}
\hline Administration & $\begin{array}{l}\text { The administration of elections, including scrutineers; the printing and } \\
\text { compilation of electoral rolls; special votes. }\end{array}$ \\
\hline Boundaries & $\begin{array}{l}\text { Any matter pertaining to electoral boundaries or the Representation } \\
\text { Commission. }\end{array}$ \\
\hline Broadcasting & The rules regulating the use of broadcast media in election campaigns. \\
\hline By-Election & $\begin{array}{l}\text { Any matter pertaining to the holding or postponement of a by-election or by- } \\
\text { elections. }\end{array}$ \\
\hline Constitution & $\begin{array}{l}\text { Constitutional matters pertaining to the conduct of elections or the period } \\
\text { between an election and the formation of a government / sitting of the } \\
\text { House. }\end{array}$ \\
\hline $\begin{array}{l}\text { Electioneering and } \\
\text { Finance }\end{array}$ & $\begin{array}{l}\text { The rules surrounding the conduct and funding of election campaigns and } \\
\text { the funding of political parties. }\end{array}$ \\
\hline Electoral System & The system by which Members of Parliament are elected. \\
\hline $\begin{array}{l}\text { Franchise and } \\
\text { Registration }\end{array}$ & The rules surrounding who can vote and/or how they must register to do so. \\
\hline Maori & Electoral matters solely affecting Maori, particularly franchise issues. \\
\hline Method of Voting & $\begin{array}{l}\text { Any matter pertaining to the way a vote is cast, e.g. the form of the ballot } \\
\text { paper or proscribed method of marking that paper. }\end{array}$ \\
\hline MP Qualification & $\begin{array}{l}\text { The rules relating to a person or existing MP's eligibility to be a Member of } \\
\text { Parliament. }\end{array}$ \\
\hline Number of MPs & $\begin{array}{l}\text { Any matter relating to the number of members in the House of } \\
\text { Representatives. }\end{array}$ \\
\hline
\end{tabular}




\begin{tabular}{|l|l|}
\hline Referendum & $\begin{array}{l}\text { Any matter relating to the holding or result of a referendum on an electoral } \\
\text { issue. }\end{array}$ \\
\hline Technical & $\begin{array}{l}\text { Any procedural, incidental or corrective measure amending an existing piece } \\
\text { of electoral legislation. }\end{array}$ \\
\hline Term Length & The length of the parliamentary term. \\
\hline
\end{tabular}

To aid analysis about the role of consensus, examined in later chapters, acts are also classified by the amount of debate generated in Parliament. Each falls into one of four categories ranging from high to none.

Table 3 - Level of Contention over Electoral Amendment Legislation

\begin{tabular}{|l|l|}
\hline High & The bill is strongly contended in most or many areas. \\
\hline Moderate & The bill creates a moderate amount of contention. \\
\hline Low & Disagreements are minor. \\
\hline None & Largely non-contentious discussion. \\
\hline
\end{tabular}

As described in chapter one, a search for consensus does not always result in an outcome of consensus. Furthermore, a contentious parliamentary process occasionally results in a consensual outcome. For this reason, acts are also classified by outcome. A distinction is made between the unanimous passage of an act and the unopposed passage of an act. Oppositions may not oppose passage of an act but may not actively support it. Occasionally, this distinction is hard to draw. In drawing the distinction, I make a subjective assessment based on the level of contention, any original opposition from the Opposition, and whether divisions were called in any stages of the bill. Another category, 'opposed only by minor parties', is used in analysing acts passed by Parliaments elected under the MMP system. As discussed in chapter seven, 
on a number of occasions the National and Labour parties have joined forces to pass legislation opposed by minor parties.

Table 4 - Outcome of Electoral Amendment Legislation

\begin{tabular}{|l|l|}
\hline Unanimous & Bill passed with full support from opposition and government \\
\hline Not Opposed & $\begin{array}{l}\text { Opposition does not oppose the bill but unanimity is either absent or } \\
\text { indeterminable. Bills that receive no division on their third reading and have } \\
\text { not been proactively supported by the opposition fall into this category. }\end{array}$ \\
\hline $\begin{array}{l}\text { No Multi-partisan } \\
\text { Support }\end{array}$ & $\begin{array}{l}\text { The major parties (National and Labour) are unanimous. Minor parties are } \\
\text { opposed. }\end{array}$ \\
\hline Opposed & $\begin{array}{l}\text { Bill passed by majority vote, opposed by the major party not in government. } \\
\text { Defeated }\end{array}$ \\
\hline Lapsed & $\begin{array}{l}\text { The bill is defeated in a vote. } \\
\text { proceed. }\end{array}$ \\
\hline
\end{tabular}

The final category considers the importance of a bill in terms of the scope and effect of each Act in comparison to other electoral bills. This delineation is necessitated by the large variation in scope and impact of various bills. The Electoral Amendment Act 1945, for example, abolished the country quota, while the Electoral Amendment Act 1972 disallowed a candidate from standing for election under a newly-adopted name.

Table 5 - Class of Electoral Amendment Legislation

\begin{tabular}{|l|l|}
\hline Milestone & $\begin{array}{l}\text { The Act stands as a milestone in New Zealand electoral law, and makes a } \\
\text { substantial and significant change to an area or areas of the electoral law. }\end{array}$ \\
\hline Major & The Act makes a substantial change to an area or areas of the electoral law. \\
\hline Minor & The Act makes a small change to an area or areas of the electoral law. \\
\hline Incidental & $\begin{array}{l}\text { The Act makes a very small and insignificant change to an area or areas of } \\
\text { the electoral law. Often split from a Statutes Amendment Bill. }\end{array}$ \\
\hline
\end{tabular}


With this classification system in mind, we turn to the history of the $1927-2007$ period. As is evident from the discussion in the following chapters, Parliament amended every part of the electoral law during the period studied. There is variety not only in the areas of electoral law amended, but in the relative importance of those areas and the scope of the amendments themselves. The changes ranged from full electoral system change to the amendment of a mistake made in the printing of an act. Large or small, however, the changes all altered or circumvented the Electoral Act 1927, 1956 or 1993. If, as established, the Electoral Act can be considered a part of the New Zealand constitution, even minor changes can have constitutional importance and are thus deserving of analysis.

While chapters four to six, which examine in detail the majority of electoral legislation, are thematically organised, if there is any point to begin an examination of co-operation and controversy in New Zealand's electoral law it is with the three Electoral Acts that have served as New Zealand's electoral rulebooks for various periods between 1927 and 2007. In addition to these acts, this chapter discusses the Electoral Amendment Act 1975, whose outcome serves as the antithesis, as such, of the Electoral Act 1956. These acts serve as useful points of context in an analysis that covers a large amount of time. Even alone, the Electoral Act 1956 and Electoral Amendment Act 1975 serve as milestones in the history of the electoral law in New Zealand. One was passed with the full consensus of the House; the other was passed with the House divided on a number of key issues. Each heralded a new era of electoral law amendment: the 1956 Act an era of consensus; the 1975 Act a move away from the search for consensus. 
First, however, some basic figures. As set out in table 6, similar amounts of electoral legislation were passed by National or National-led, and Labour or Labour-led, governments over the 80 years covered by this thesis. When classified by class of importance, the numbers are comparable.

Table 6 - Electoral and Electoral Amendment acts passed by National or National-led and Labour or Labour-led Governments 1927-2007

\begin{tabular}{|c|c|c|c|c|}
\cline { 2 - 5 } \multicolumn{2}{c|}{} & $\begin{array}{c}\text { National or } \\
\text { National- } \\
\text { Led }\end{array}$ & $\begin{array}{c}\text { Labour or } \\
\text { Labour- } \\
\text { Led }\end{array}$ & TOTAL \\
\hline \multirow{4}{*}{\begin{tabular}{c}
$*$ \\
\cline { 2 - 5 }
\end{tabular}} & Milestone & 2 & 1 & 3 \\
\cline { 2 - 5 } & Major & 11 & 11 & 22 \\
\cline { 2 - 5 } & Minor & 10 & 12 & 22 \\
\hline & Incidental & 9 & 7 & 16 \\
\hline
\end{tabular}

Parliament passed 32 electoral related acts under National and National-led governments, and 31 under Labour and Labour-led governments.

As set out in table 7, there are only several notable differences between the subject matter of legislation passed by different National and National-led, or Labour and Labour-led, governments in New Zealand. Labour and Labour-led governments passed more legislation relating to the length of the parliamentary term, the qualifications for being a Member of Parliament and broadcasting. National and National-led governments passed more measures affecting administration, boundaries, franchise, referenda legislation and technical amendments. While National and Labour governments passed the same amount of electoral amendment

\footnotetext{
${ }^{48}$ In addition to this number, the Coalition Government that held office between the study's starting date in 1927 and the election of the first Labour Government in 1935 passed three pieces of electoral legislation.
} 
legislation, National and National-led governments oversaw the passage of more omnibus electoral acts. This is evident in the subject category figures, which are 69 to 54. This number must be contextualised, however, by the fact National spent slightly longer in government than Labour during the 80 years in question: 38 years to 34 years.

An investigation of these figures must start with the Electoral Act 1927. While a noncontentious, purely amalgamative Act, it was New Zealand's first consolidated Electoral Act, and the starting point for our analysis. The Act was entirely a consolidating measure, ${ }^{49}$ which amalgamated the existing electoral law from the Legislature Act 1908 and several other acts. The impetus for its introduction came from the Electoral Department rather than the government. Mr McLeod, Minister for the Electoral Department, apologised to the House for troubling it with the measure. ${ }^{50}$ The Labour Opposition concurred with the measure; its leader Henry Holland agreed consolidation was "very necessary". ${ }^{51}$ No other Members rose to speak on the bill, ${ }^{52}$ which three days later received its second and third readings with no further debate. ${ }^{53}$ Nor did any debate arise in the Legislative Council; its leader, Sir Francis Bell, declared the bill "a matter affecting entirely the privileges of the House" to be passed without debate and sent back to the other chamber. ${ }^{54}$

\footnotetext{
49215 NZPD 590, 3 November 1927.

50215 NZPD 590, 3 November 1927.

51215 NZPD 590, 3 November 1927.

52215 NZPD 435, 31 October 1927.

53215 NZPD 592, 3 November 1927.

${ }^{54} 215$ NZPD 721, 8 November 1927.
} 
Table 7 - Electoral Law Changes introduced by National or National-led and Labour or Labour-led Governments 1927 - 2007 by Subject ${ }^{55}$

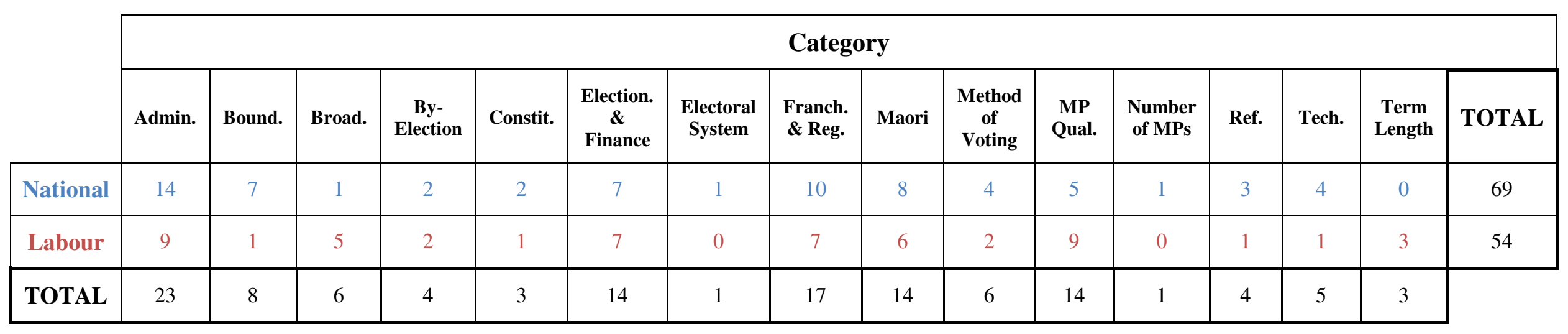

\footnotetext{
${ }^{55}$ Note that, as many acts are categorised in multiple categories, the sum of category totals exceeds the total number of electoral amendment acts passed.
} 
The Electoral Act 1956 Act, which replaced the Electoral Act 1927, consolidated or substantially amended every piece of existing New Zealand electoral law. Until 1993, it served as the primary legislation amended by all amendment acts passed by subsequent governments. While its scope was extensive, the process by which it was passed and conventions it created were arguably more influential. Geoffrey Palmer has referred to 1956 as "an epoch-making time in the electoral law of this country". 56 Indeed, the example of the Electoral Act 1956, although now replaced, retains significant influence in constitutional debate in the present day. ${ }^{57}$ The Act was the first comprehensive revision of the electoral law ever made in New Zealand. ${ }^{58}$ The Department of Justice spent over half a year developing the bill, whose stated objects were "removal of the many uncertainties that arise in determining the law within the main Act of 1927 and its numerous confusing amendments; improving and simplifying procedures, while preserving proper safeguards; and providing better enrolment and voting facilities." 59

There is a question as to why the Act came about. One interpretation is that the Electoral Act 1956 was a response to partisan electoral amendments made by the Forbes administration in 1934 and the Fraser Government in 1946, discussed in chapters four and five. A.C. Brassington argues that "appreciation of these events had brought our legislators to the point of defining the arena in which the political parties were in future to deploy their forces." ${ }^{, 60}$ This latter point may have been a result of the Act, yet it was probably only one motivation behind the Bill's introduction. Keith

\footnotetext{
${ }^{56} 433$ NZPD 3869, 1 October 1980.

57 The Act was in fact only one of three major reforms made in 1956 (the others being the Evidence Act and the Trustee Act) that have only recently been updated.

${ }^{58}$ Report of the Department of Justice for the Year 1956-57 [1957] AJHR H.20.

${ }^{59}$ Report of the Department of Justice for the Year 1955-56 [1956] AJHR H.20.

${ }^{60}$ A.C. Brassington, 'The Constitution of New Zealand - Aspects of Change and Development', New Zealand Law Journal, 4 June 1963, pp. 217-218.
} 
Jackson states that the primary motivation behind the Act was National Prime Minister Sidney Holland's attempt to appease his critics within the National Party over the abolition of the second chamber. ${ }^{61}$ Five years after the abolition of the Legislative Council, Holland, whose dislike of the upper house was the major reason behind its abolition, found himself under pressure to institute a new senate. Holland had promised at the 1955 National Party Conference to undertake legislation to "safeguard the existing rights of the people to elect the Government of their choice". 62 The electoral legislation was a way of averting a course of action Holland did not want to take: restoration of the upper house. It is paradoxical, perhaps, that the Act that set the non-partisan tone of electoral law debate for the next two decades was introduced as a somewhat self-interested action by a Prime Minister under pressure from sectors within his own party.

The major innovation of the Electoral Act 1956, and the feature that allowed Holland to claim the Act stood as a constitutional safeguard (akin, he argued, to that provided by an upper house), was the introduction of entrenchment, discussed in chapter two. While the passage of the entrenched provisions was the result of a unanimous Parliament agreeing on a "fair and impartial method of protecting the electoral system", ${ }^{63}$ their inception was primarily the work of John Marshall, then Minister of Justice. ${ }^{64}$ Marshall believed the provisions represented "a major advance in the progress of democratic Government in New Zealand" and a "genuine... successful attempt to place the structure of the law above and beyond the influence of

${ }^{61}$ W.K. Jackson, The New Zealand Legislative Council, University of Otago Press, Dunedin, 1972, p. 202.

${ }^{62}$ Ibid.

${ }^{63} 310$ NZPD 2840, 26 October 1956.

${ }^{64}$ See Marshall's introduction in The Reform of Parliament, John Marshall (ed.), New Zealand Institute of Public Administration, Wellington 1978. 
Government and Party." ${ }^{65}$ Likewise, Labour leader Walter Nash saw entrenchment as ensuring "democratic principles would prevail in the determination of who should write the laws." 66

Two points are important to note on the subject of the 1956 entrenched provisions. First, they were not the only important provisions present in the Bill. Other provisions, while not similarly entrenched, were arguably of equal constitutional importance. ${ }^{67}$ The clauses relating to the Maori seats, for example, were left unentrenched and thus alterable by any majority government. Alan Robinson notes a second ballot or preferential voting system could be introduced by a simple majority of the House, as the sections of the Electoral Act relating to the voting system were not entrenched. ${ }^{68}$ As Scott points out, however, "[t]he entrenched sections... cover amongst other things the only constitutional subjects on which there has been bitter party controversy during this century." ${ }^{, 99}$ Ultimately, six sections were entrenched. As discussed in chapter two, the entrenchment clause was not entrenched itself. So the entrenched provisions were - theoretically, at least - able to be amended by a government that repealed the entrenchment clause first. The entrenchment clauses, however, were as much about creating a conventional duty as they did a statutory duty. The language of those who wrote or spoke about the Act at the time centred on the word 'moral'. Marshall said the effect of the entrenched provisions is not their "legal force to bind future Parliaments but... their moral force as representing the unanimous view of Parliament", ${ }^{70}$ This view is echoed by Scott: ${ }^{71}$

\footnotetext{
65310 NZPD 2839, 26 October 1956.

66310 NZPD 2843, 26 October 1956.

${ }^{67}$ Robinson, 'Parliament in New Zealand', p. 145.

${ }^{68}$ Ibid.

${ }^{69}$ Scott, The New Zealand Constitution, p. 6.

${ }^{70} 310$ NZPD 2839, 26 October 1956.

${ }^{71}$ Scott, The New Zealand Constitution, p. 8.
} 
Though the entrenched provisions of the Electoral Act have no superior legal sanctity of an effective nature, they have a superior moral sanctity. The Act was passed unanimously, and registers an agreement between the parties that neither party will employ a bare majority to amend or repeal any of the entrenched provisions in defiance of the ostensible intention of section 189.

So future governments had a 'moral' duty to adhere to the consensus reached between National and Labour in 1956. Parliament may not have been, in the strictest sense, binding its successors, but it was imposing a series of expectations on their future behaviour.

The process by which the Electoral Act was passed was unlike the partisan processes of the previous two decades. Indeed, at the time it was passed, the Electoral Act 1956 was unique. Not only did government and opposition engage to produce New Zealand's first totally bi-partisan piece of major electoral legislation, but much of this engagement occurred not in the House, but at the Electoral Bill Select Committee, instituted especially for the task. This committee consisted of ten Members, six from government and four from opposition - the usual distribution of members under First Past the Post, the system by which Members of Parliament were elected until $1996 .{ }^{72}$ The Committee met six times in nine days before reporting back to the House. Both parties found the other willing to compromise and shared a primary aim of reaching consensus. ${ }^{73}$ The Committee reached what Marshall described as "almost complete unanimity on the Bill and on the amendments made in the committee."74 Scott, who in the course of writing his 1962 work on the New Zealand constitution, had access to a number of people who had served on the 1956 Committee, outlines the precise

\footnotetext{
72310 NZPD 2451, 12 October 1956; The Committee members were Cooksley, Hackett, Hanan, Harker, Holloway, Johnstone, Mathison, Skinner, Smith, and Marshall.

${ }^{73}$ John Marshall in The Reform of Parliament, John Marshall (ed.), p. 10.

74310 NZPD 2841, 26 October 1956.
} 
detail of how consensus was reached. ${ }^{75}$ Four provisions in the Bill were in dispute between the government and opposition. Perhaps unsurprisingly, all four provisions related to boundaries and the Representation Commission - matters that had been modified extensively and controversially in the 1945 Electoral Amendment Act, discussed in detail in chapter five. Ultimately, two provisions were settled in line with the National Party's position and two in favour of the Labour Party's position. ${ }^{76}$

Labour raised concerns about the composition of the Representation Commission. Labour Member Arnold Nordmeyer said National's most recent appointments to the Commission were "very much to the advantage of the present Government" and allowed "the commission to make a very big difference in the size of electorates". 77 Nash wanted "the power to be taken away from any Government to determine electoral boundaries... If the boundaries could be fixed by an independent commission it might be more helpful., ${ }^{, 78}$ The situation as it stood, however, only existed due to the changes introduced by the previous Labour Government in the Electoral Amendment Act 1945. As Atkinson argues, "the decisions of the Nationalappointed Commission in 1952, which the opposition alleged had prejudiced the 1954 election in the Government's favour, had now convinced Labour of the evils of its own partisan model.,"79

The alteration by the 1956 Act of the Representation Commission was substantial. The government-appointed majority was removed and an impartial board put in place. This consisted of the Surveyor-General, Government Statistician, Chief

\footnotetext{
${ }^{75}$ Scott, The New Zealand Constitution, p. 8.

${ }^{76}$ Scott, The New Zealand Constitution, p. 8.

77 110 NZPD 2450, 12 October 1956.

${ }^{78} 310$ NZPD 2844, 26 October 1956.

${ }^{79}$ Atkinson, Adventures in Democracy: A History of the Vote in New Zealand, p. 168.
} 
Electoral Officer, and the Director-General of the Post and Telegraph Department. One government and one opposition representative were appointed and the chair nominated by the Commission itself. The Labour Party's advocacy of a reformed, impartial, Representation Commission was the reverse position to that taken by the previous Labour Government and a tacit acknowledgement that the politicisation of the Commission in 1945 had been an error. The tolerance by which electorates may vary from the electoral quota was also reduced from 7.5 percent to 5 per cent. ${ }^{80}$ National got its wish for electoral boundaries to remain based on total population basis (the change made in the Electoral Amendment Act 1950) instead of total adult population (the change made in the Electoral Amendment Act 1945) and for the Representation Commission's terms of reference to remain unmodified. ${ }^{81}$

While these major issues were resolved, some others were not fully agreed upon and, instead, set to one side. The issue of the voting age was left unresolved. Nash was uncertain if 21 was the age when "democracy commences" but nonetheless supported entrenchment of the voting age at $21 .^{82}$ Marshall said in the House that Opposition members wanted to be able to canvass outside voting booths, but this was nonetheless banned by the Act. ${ }^{83}$ On other issues (including some that would, in later years, become areas of disagreement), both parties were agreed. On the franchise, for example, Nash supported the government's provisions on restricting the vote to British subjects. ${ }^{84}$ With nearly all disagreements resolved in the Select Committee, most debate in the House concerned minor points or technicalities. For example,

\footnotetext{
${ }^{80}$ Scott, The New Zealand Constitution, p. 8

81 Ibid.

82310 NZPD 2843, 26 October 1956.

${ }^{83} 310$ NZPD 2842, 26 October 1956.

${ }^{84} 310$ NZPD 2843, 26 October 1956.
} 
would offering a cup of tea count as 'treating'? ${ }^{85}$ Or would a seaman who had resided in an electorate for the required three months but spent part of that period at sea still qualify ${ }^{86}$

Overall, both government and opposition saw the passage of the Act as a resounding success. Nash did not think "the attempt to put forward the best possible Bill could have been improved... The objective on both sides was the same." ${ }^{87}$ National Member of Parliament Ralph Hanan hailed "a splendid Bill, almost a historic piece of legislation in which two political parties have got together to make a major change that will help to preserve the constitutional rights of the individual to exercise his vote and preserve his sacred right of the secrecy of the ballot" ${ }^{88}$ It was, overall, the consensual spirit in which the government and opposition operated that made the Electoral Act 1956 such a success, entrenching both the Act's statutory provisions into law, and the process by which the Act was passed as a burgeoning political convention. Ralph Hanan asserted during the debate that "the only possible way to satisfactorily make a major change in the electoral laws is where you have an element of agreement between the political parties". ${ }^{89}$ It was agreed by both sides that the 1956 Act was a satisfactory change. Ultimately, it was Marshall who described most succinctly the convention created by the 1956 Act - a convention that would dictate the process by which electoral amendment would occur over the following two decades, and a convention that, as evident from the comments of Wayne Mapp and Phil Goff noted in chapter one, still holds sway today: $:^{90}$

\footnotetext{
85310 NZPD 2846-47, 26 October 1956.

86310 NZPD 2841, 26 October 1956.

87310 NZPD 2843, 26 October 1956.

88310 NZPD 2852, 26 October 1956.

${ }^{89} 310$ NZPD 2850, 26 October 1956.

${ }^{90}$ John Marshall in The Reform of Parliament, p. 7.
} 
As a general rule, major decisions touching the institution or procedures of Parliament are not imposed by the majority party. They are usually bi-partisan decisions reached after much discussion and often by way of compromise.

It is evident in the following chapters that the Electoral Act 1956, which followed two decades of partisan amendment to the electoral law, set a non-partisan tone for the following two decades. Before considering any other electoral amendments in detail, however, it is useful to examine the first Act to depart from the convention of consensus that had been established and followed since 1956. This Act was the Electoral Amendment Act 1975, passed under the Labour Government led by Bill Rowling. The Act contained a range of amendments to various provisions of the Electoral Act. While it is not the aim of this thesis to write a full history of the Act, a number of its amendments were notable for either their influence or the controversy they caused. These changes included the extension to permanent residents of the right to vote, allowing Maori to choose between the Maori roll and the General roll, and removing the disqualification provisions that prevented prisoners from voting. The Act changed the residential requirement of the Electoral Act from three months to one month and allowed any eligible person to vote on Election Day whether or not he or she was enrolled as an elector. As it was accepted by both sides that Labour was advantaged by a shorter period, and National by a longer period, and that Labour was advantaged by late or no registration, and National the opposite, accusations of selfinterest flew from opposition to government for supporting the change and from government to opposition for opposing it. ${ }^{91}$ Interestingly, the National Opposition did not make a great deal of comment on clause 17 of the Electoral Amendment Act 1975, which removed the requirement of being a British subject to vote. Any discussion of this substantial amendment to the electoral law was overtaken by the

91397 NZPD 1067, 2 May 1975. 
shrill debate that ensued on the matters of disagreement. The extension of the franchise to prisoners roused the most debate and attempts to mobilise public opinion against the government. ${ }^{92}$

Despite the government's subsequent defeat on several key provisions, the process through which the Bill was developed and introduced started in a relatively consensual and consultative manner. The House instituted an Electoral Act Select Committee in November 1973 to consider what amendments were necessary to the Electoral Act. ${ }^{93}$ While the government held a majority on the Committee (as, indeed, was the norm), the institution of a select committee before an electoral amendment bill was even drafted was an innovation and perhaps boded well for a bi-partisan legislative process. In addition, there was a concerted effort to involve the public in the Committee's deliberations. Advertisements were inserted on two occasions in the daily newspapers inviting those interested to make submissions. Thirty-four submissions were made and most of those making submissions were asked to appear before the Committee. Eighteen of the organisations or individuals did so. ${ }^{94}$ The Committee met on 12 occasions between 1973 and 1975 and issued several interim reports. Its interim report to the House on 17 September 1974 unanimously recommended the voting age be lowered to $18,,^{95}$ and this recommendation was carried out in the Electoral Amendment Act 1974, discussed in chapter four. Altogether, out of 55 recommendations for the 1975 Act, the Committee unanimously recommended 45 and ten were recommended by the government's majority on the Committee. ${ }^{96}$ Several clauses in the Bill, however, attempted to amend or repeal

\footnotetext{
92399 NZPD 3082, 17 July 1975.

${ }^{93}$ Final Report of the Electoral Act Committee, [1975] AJHR I.15, p. 4.

${ }^{94}$ Ibid.

${ }^{95}$ Ibid.

${ }^{96}$ Ibid.
} 
entrenched provisions of the Electoral Act 1956. Ultimately, however, not all of these provisions passed. Some did not attain the required $75 \%$ support of the House and were removed from the Bill during the Committee of the Whole House stage. This is the first example of the defeat of parts of a government bill through the entrenchment clause of the Electoral Act $1956 .^{97}$ As the government realised, and Minister of Justice Martyn Finlay said in the House: $:^{98}$

\begin{abstract}
When the committee was set up it was hoped by this party, and I suspect by the Opposition, that the recommendations produced would be agreed to by both parties. Unfortunately this did not eventuate... some, and many of the most important, recommendations were made by a majority only of the members of the committee. Normally this does not matter, because in the House the majority rules; but in the Electoral Act six matters are reserved and may be changed only by 75 percent of the membership of the House...
\end{abstract}

It was at this stage in the process that the government took a different path from that taken by the then National Government in 1966, when that government realised Opposition support for a change to an entrenched clause would not be forthcoming. ${ }^{99}$ Then, the Holyoake Government had withdrawn its bill. The Rowling Government, however, decided to continue with the bill as drafted and not remove the proposed amendments to the entrenched provisions that the Opposition did not support.

During the debate, Marshall said he hoped the clauses could still be discussed and that some compromise could be reached. ${ }^{100}$ However, another National MP (and later Prime Minister) Robert Muldoon said in the same debate that the Opposition would oppose the provisions on which the Committee divided. Those that were entrenched

\footnotetext{
97 In 1966, the Holyoake Government withdrew its Electoral Amendment Bill after the opposition declined to support it.

98397 NZPD 1187, 20 May 1975.

${ }^{99}$ See discussion in Chapter Five.

100397 NZPD 1070, 2 May 1975.
} 
would simply fail. ${ }^{101}$ Nonetheless, the Opposition offered full support to the remaining 45 clauses, and Muldoon assured the government that the Bill would be passed "to some extent at least." 102

It was not long, however, until a level of acrimony arose in the debate on the contested clauses, and this acrimony spilled over into the debate as a whole. The Electoral Amendment Bill was characterised by the Opposition as "a Labour Party Bill", ${ }^{103}$ and "gerrymandering of the worst order". ${ }^{104}$ It was argued that "the Government [was] insisting on trying to amend the Electoral Act so that it will electorally favour the Labour Party, and for no other reason."105 Labour MP Jonathan Hunt, who had chaired the Electoral Law Select Committee, countered that there "will be no overall advantage to either side. I challenge anyone to produce any figure which would prove that, throughout New Zealand, there will be any advantage to either side." ${ }^{106}$ But the government was especially vulnerable to accusations of selfinterest in its changes to the election law because 1975 was an election year. It seems the government was conscious of this problem. On introducing the bill, Dr Finlay (Minister of Justice) was "most concerned to see that [the bill] is introduced into the House this week, before Parliament goes into recess... I think it is important that we should let the people know the intentions of the Government as long as possible before the election this year."

\footnotetext{
101397 NZPD 1068, 2 May 1975.

102397 NZPD 1069, 2 May 1975.

103397 NZPD 1194. 20 May 1975.

104397 NZPD 1071, 2 May 1975.

105397 NZPD 1194, 20 May 1975.

106397 NZPD 1070, 2 May 1975.

107397 NZPD 1067. 2 May 1975.
} 
For the opposition, the fact it was an election year allowed it to promise to maximum political advantage that, if elected, it would change the law. On a number of occasions during the debate, Muldoon promised the contested changes would be repealed and replaced by the existing provisions in the event of a National victory at the 1975 election. ${ }^{108}$ After an extensive committee stage in which the Opposition attempted to obstruct passage of the bill through numerous amendments, the House divided 42-28, along party lines, on the Bill's third reading. The proposed changes to the entrenched provisions were defeated in the committee stages and removed from the final bill. The vote saw the end of the most contentious debate on electoral law in decades. The Electoral Amendment Act 1975 and, indeed, the new National government's subsequent repeal of much of the Act, marked the end of two decades of consensus on the amendment of the electoral law.

Ultimately, the entrenched provisions, which were not doubly entrenched themselves, worked (as intended) to prevent a disunited Parliament from amending certain provisions. While Marshall, the architect of the provisions, expressed relief they had not been trampled upon by the government, ${ }^{109}$ there was never any question of this happening. By 1975, the entrenched provisions were firmly ensconced as an influential part of New Zealand's constitution. In terms of process and consensus, John Marshall believed 1975 had lacked "the spirit of compromise" that had existed in $1956:^{110}$

As a result of the changes introduced by the Government in this Bill the stability of our electoral law is likely to go by the board in several important respects. This could mean... that whichever party becomes the Government there are likely to be some changes in that electoral law. So we will now have the unsatisfactory

\footnotetext{
108397 NZPD 1072, 2 May 1975.

109397 NZPD 1072, 2 May 1975.

110298 NZPD 2097, 12 June 1975.
} 
situation where the electoral law means one thing when one Government is in office and another thing... when another Government is in office.

Marshall's contention was at least partially accurate. Whether it was the fault of an unmovable government, an unmovable opposition, or some combination of the two, the "spirit" of 1956 had not been present in the debate of 1975.

It remains to mention the Electoral Act 1993. The Act was a complete rewrite of the Electoral Act 1956, written to incorporate the MMP system. It was passed but only came into effect when the public voted for MMP in the 1993 Referendum, provided for in the 1993 Electoral Referendum Act. The Bill also included provisions for a Senate, which could be introduced if the public voted to retain FPP. These provisions were split into a separate bill before the Act was passed and ultimately lapsed. On this occasion, the Electoral Law Committee engaged in one of the most extensive consultation processes undertaken by a parliamentary Select Committee. The Committee considered the bill for six months and considered 430 written and 167 oral submissions in six different centres. ${ }^{111}$ Committee chair, National MP Murray McCully, summarised the process of consensus and compromise that had occurred on the Committee: ${ }^{112}$

The proposal that I report back to the House today does not represent the ideal model of any individual member of the committee. There are respects in which each of us would prefer something different. However, members of the committee decided that they had a duty to the House, and, indeed, to the country, to forge a consensus that would enable us to fashion a workable and consistent model of an MMP system, acceptable in all its key components to the majority. In that respect the Bill has seen quite an unprecedented level of consultation by select committee members with their parliamentary colleagues.

111536 NZPD 16728, 22 July 1993.

${ }^{112} 536$ NZPD 16728, 22 July 1993. 
There was some dissent over whether the compromise in the Committee had in fact been excessive, and that the committee had not produced the best possible form of MMP. ${ }^{113}$ In the second reading debate the government announced it would not seek closure motions in the second reading, committee stages, or the third reading, in order to allow the topic to be exhaustively debated. The House divided a number of times during the Committee stage on whether individual clauses stand part and whether amendments to clauses be accepted. This was the first truly bi-partisan, non-party, set of voting in Parliament on an electoral matter in NZ's history. Labour and National MPs mixed in the Ayes and Noes lobbies according to their consciences. At the end of the committee stages, the electoral reform bill was divided into the Electoral Bill 1993 and the Electoral Referendum Bill (No 2) 1993 and both were passed without the taking of a division. At the time of the third reading, Parliament had spent an unprecedented 30 1/2 hours debating the issue in the House. ${ }^{114}$

The acts of 1956, 1975 and 1993, while all broadly different in scope, subject matter and motivation, can be viewed as milestones in New Zealand's electoral law in the period studied. After the Electoral Act 1927 set up the unified Act; the 1956 Act instituted the entrenched provisions and a preferred process for amendment of the electoral law more generally; the 1975 Act tested the entrenchment process and broke the mould of consensus in amendment of other areas of the law; and the 1993 Act saw Members of Parliament from all parties voting on conscience, rather than party lines, on electoral system change - the most significant of all areas of electoral law reform. Together, the acts form a useful structure for analysis. Chapters four to six now proceed to fill in the gaps.

\footnotetext{
${ }^{113}$ See comments of David Caygill, 536 NZPD 16731, 22 July 1993.

114537 NZPD 17268, 3 August 1993.
} 


\section{Chapter Four Parliament and Electoral Rules}

This chapter and the two that follow it cover the various parts of the electoral law amended by Parliament between 1927 and 2007. This chapter examines the law relating to Parliament and the formation of a government. Specifically, it considers the length of the parliamentary term, number of Members of Parliament in the House, the qualifications to be a Member of Parliament, formation of government and legislative proposals for alternative electoral systems.

It is appropriate, perhaps, to start with one of the most controversial changes to the electoral law: the Electoral Amendment Act 1934.

\section{Term Length}

The length of the parliamentary term rarely arose throughout the 80 years studied. On the two occasions a proposal for a longer term went to a referendum it was rejected soundly by the public. The general unpopularity of the idea led to discussion of the term only coming up on a sporadic basis over the years.

Term length, however, is the area of the electoral law that saw perhaps the most selfserving move of a government in the history of New Zealand's electoral law when, in 1932, the Forbes Coalition Government inserted into a Finance Act a clause that extended the life of the current Parliament from three to four years. In 1934, the Labour Party opposition sought to undo the relevant clauses of the Finance Act 1932 and bring the current Parliament to an end at the end of the three years for which it had been elected. The Private Member's Bill introduced by Labour Leader Michael 
Joseph Savage was ruled out of order as involving an appropriation. ${ }^{115}$ Later that year the Coalition Government, led by George Forbes, successfully introduced an act that applied the four year extension of the current parliamentary term to all future parliamentary terms. The opposition to the bill, eventually passed by a simple majority, was notable in that it employed a number of arguments which would become common arguments used by oppositions opposed to particular electoral legislation over the next eighty years.

The first of these arguments was an assertion that the government was acting out of self-interested motives. While Forbes' response to accusations of self-interest was that "[t]he question of the unpopularity of a Government does not enter the matter", ${ }^{116}$ Labour members claimed the government's actions stemmed from "the danger that if there was a general election this year the Opposition might win", ${ }^{117}$ and that the real reason for the government's action is that "it has grave reasons to fear the result of facing the people". ${ }^{118}$ The Government had, however, already prolonged its own term in the Finance Act 1932. A future Labour Government had as much to gain from the Electoral Amendment Bill 1934 as did the incumbent government. Against this, however, was the lack of public support for a four-year term in the first place. As Labour Member Bob Semple said, the 1934 Act was "an action which the people will resent with the bitterest antagonism". ${ }^{119}$ In this sense, the government was taking a risk from which, by 1934, it stood only to lose.

\footnotetext{
115238 NZPD 764, 27 July 1934.

116239 NZPD 144, 14 August 1934.

117238 NZPD 627, 24 July 1934.

118238 NZPD 629, 24 July 1934.

119240 NZPD 351, 4 October 1934.
} 
While the extension of the current term of Parliament through the Finance Act 1932 was arguably self-interested, ascertaining the true motive of the Coalition government in passing the Electoral Amendment Act 1934 is a difficult task. Mr Stallworthy, a Labour MP, claimed the bill was to "cover up, in some degree at least, its sordid purpose in extending its own life and the life of this Parliament only." ${ }^{120}$ Indeed, $\mathrm{Mr}$ Kyle, later National MP for Riccarton, later publicly regretted his former party's decision to lengthen the term: ${ }^{121}$

Sometimes I almost wish, for the Labour party's sake, that we had not made that Parliament a four-year Parliament. The Labour party then would not have come in at such a flourishing time, when the whole of the trade and commerce had been practically restored to beyond what it was before the early slump.

The second argument made by the Opposition against the bill also received multiple airings in the decades after 1934. This was that the government had no mandate from the public to make such a significant change to the electoral law. This was an argument that, for the first time, recognised the special nature of the electoral law, by emphasising the role of public consent in its amendment. In light of the lack of public consultation or notification, Labour Members called the bill "a breach of faith", ${ }^{122}$ and "a flagrant breach of the constitutional British practice."123 There was recognition, then, that the electoral law was law that perhaps required special treatment. On this count, two criticisms by Labour Members are of particular interest. The Labour Leader, Michael Joseph Savage, said "[t]he correct procedure would be to introduce the Bill after having consulted the people. This appears to be acting first and asking authority afterwards, surely not the correct procedure at all."124 Bob Semple, another Labour Member, said "this Parliament has no constitutional nor

238 NZPD 626, 24 July 1934.

121249 NZPD 823, 30 November 1937.

122238 NZPD 625, 24 July 1934.

${ }^{123} 238$ NZPD 626, 24 July 1934.

${ }^{124} 238$ NZPD 625, 24 July 1934. 
moral right to interfere with the law which has governed this country for many, many years. It certainly has a right, a duty, to consult the people on the question." 125 So the position of the Opposition was that, while there was no doubting the government's discretion to introduce such legislation, in matters of electoral law, a mere right did not necessarily constitute the correct way to go about legislating. Indeed, the government had a moral obligation to seek public consent. Here can be seen in its infant stages what would, in the 1950s, emerge in the entrenched provisions of the Electoral Act 1956.

The final feature of the debate over the Electoral Amendment Bill 1934 would also, over the following years, become a common aspect of electoral law debate. This was the threat by the Opposition, during debate, to repeal the legislation when it next formed a government. On this count, Savage said: ${ }^{126}$

It does seem to me to be a remarkable move on the part of the Government, because if it is not here next time - and I sincerely hope it will not be - the next Government can repeal the law at once, so there does not seem to be any reason at all for the Bill being here.

This was an interesting comment which somehow avoided the more intriguing issue. Although a four year term would have benefited an incoming Labour Government, it nonetheless pledged to repeal the Act in the event of such a victory. The same approach was taken by the National Opposition in 2007 when it opposed the Electoral Finance Act. In spite of the substantial advantages the Act conferred on an incumbent government, the National Government, once in power, repealed the Act. There is an argument to be made, however, that oppositions that promise repeal are then politically bound to carry through on those promises. In both 1934 and 2007, both

125239 NZPD 163, 14 August 1934.

${ }^{126} 238$ NZPD 625, 20 July 1934. 
opposition parties had already played an adversarial and partisan role, and made political capital out of unpopular moves by the government of the time. Once in power, they then had to follow their pre-election pledges. The 1934 Bill was ultimately passed by a simple majority along party lines, ${ }^{127}$ with the Opposition forcing divisions on most clauses. ${ }^{128}$ Despite the furore over the bill in the House, not one objection was raised against the Bill in the Legislative Council. It passed all its stages with a minimum of debate and no divisions. The only part of the debate of special note is an extraordinary closing statement from Mr Masters, the Leader of the wholly appointed Council, who said "I think that generally this provision will be welcomed by the people of the Dominion. We all know that general elections have an unsettling and disturbing influence upon the whole community." ${ }^{\prime 29}$ When the Savage Government did repeal the law in 1937, the Opposition raised several points of contention but did not vote against the bill. Again, the Legislative Council proved itself merely an adjunct to the legislative process: it considered the Bill for around ten minutes on December 2, 1937 with no debate and passed it through all three readings. ${ }^{130}$ From 1937 , the issue of the parliamentary term did not receive a great deal of debate in the House although, in 1941 and 1942, a House united by wartime passed two acts, each of which delayed the holding of the General Election by a year.

Two acts legislated for referenda on the issue of the parliamentary term. The Electoral Poll Act was passed by the Holyoake Government in 1967 and the Term Poll Act by the Palmer Government in 1990. In one sense, these acts stand somewhat apart from other electoral legislation because they did not amend the electoral law themselves.

\footnotetext{
127240 NZPD 359, 4 October 1934.

128240 NZPD 349, 4 October 1934.

129240 NZPD 441, 10 October 1934.

130249 NZPD 888-890, 30 November 1937.
} 
The 1967 Act, however, provides the first instance of a government proposing the amendment of an entrenched provision (the parliamentary term) by taking the issue to the public, where a 50\% majority was sufficient rather than the 75 percent parliamentary majority required for a similar amendment. The referral of the length of the parliamentary term to the public directly, however, perhaps underscored the constitutional importance of the matter. As it happened, the proposal was defeated by a sizeable majority $-678,960$ to $317,973 .{ }^{131}$ The 1967 Act is interesting for its process rather than its result. It provides an example of consensus politics around an electoral issue at work. While the bill did not directly affect the electoral law - and, indeed, this may be a primary reason behind the bipartisan way in which it was debated - it appears the government did attempt, at least, to make the process a consensual and open one. After referring the bill to the Statutes Revision Committee, ${ }^{132}$ the government acceded to the opposition's suggestion for a publication to be prepared setting out the principal arguments both for and against the issue. ${ }^{133}$ Holyoake proposed that, to avoid a "suspect" statement from one political party, Parliament should issue a pamphlet. ${ }^{134}$ Most importantly, he said the government would consider the matter "in a bi-partisan way". ${ }^{135}$ This was the first time the word bi-partisan was mentioned in a debate about the electoral law in New Zealand. The next proposal for a referendum on term length took place two decades later in 1990, when the Term Poll Act 1990 was passed as part of a broader Electoral Reform Bill introduced by the Labour Government, at that stage led by Geoffrey Palmer. This allowed for a referendum to extend the parliamentary term from three to

\footnotetext{
${ }^{131}$ Alan Robinson, 'Parliament in New Zealand', p. 147.

132350 NZPD 862, 25 May 1967.

133350 NZPD 863, 25 May 1967.

134350 NZPD 863, 25 May 1967.

135350 NZPD 863-64, 25 May 1967.
} 
four years. The bill garnered no opposition from the Opposition and the proposal was defeated solidly at the referendum.

While the topic of term length was at its most controversial during the 1930s, conversely, the issue of how many MPs should be in Parliament grew in its controversy over the eighty years studied.

\section{Number of MPs}

The issue of how many Members of Parliament should sit in the House was considered by the Royal Commission on the Electoral System in 1986. Before the introduction of MMP, however, the most controversial change in this area occurred in 1965.

The Electoral Amendment Act 1965 gave effect to the National Government's election promise to fix the parliamentary representation for the South Island at 25 seats and establish a quota for the North Island seats according to population growth. Maori representation was left untouched. ${ }^{136}$ When passed, the Act increased the number of members of Parliament for the first time since it was settled at 80 in 1900. ${ }^{137}$ The Bill had been signalled in the National Party's 1963 election manifesto, and the ensuing debate was long, technical and occasionally furious. By the time the bill received its third reading, it had received five times as much debate as the Electoral Act 1956. Part of the reason behind the debate's length was that the Bill was the first electoral bill to amend an entrenched provision of the Electoral Act, and so required the consent of three-quarters of the House. While the Labour Party

${ }^{136} 342$ NZPD 62, 2 June 1965.

137343 NZPD 1547, 29 July 1965. 
eventually supported the bill, it exercised the political weight conferred on an Opposition by the entrenched provisions to the fullest extent.

The split between government and opposition occurred wholly around the question of whether the number of South Island seats should be raised to 25 or to 26 . National had pledged 25 in its manifesto and Labour 26 in its manifesto. The parties were broadly in agreement that an increase in the number of MPs was called for, in order to provide a further range of "talent" available for Cabinet (an argument also put forward by proponents of the restoration of the second chamber) and to reduce the select committee workload of MPs. In line with the 'spirit' of 1956, Holyoake was of the view that "no changes [to the electoral law] should be made without the permission of and a mandate from the people." ${ }^{138}$ As the change had been signalled in the National manifesto, Holyoake claimed the government had a mandate to make his changes.

There was no real argument from the opposition on this point. Indeed, one of the major criticisms of the 1934 and 1945 Electoral Amendment acts was that the government did not have a mandate to make the changes. Yet in 1965 there was an added complication: several of the amendments proposed by the government affected entrenched provisions and, thus, required the support of the Labour Party in order to pass. ${ }^{139}$ Marshall claimed "because the Government has a mandate for an amendment increasing the South Island seats to 25 , there is, I would say, a moral obligation on the

\footnotetext{
138343 NZPD 1661, 4 August 1965.

139 The passage of the Electoral Amendment Bill 1965 was further complicated by Holyoake's interpretation of the 1956 Electoral Act clause requiring the support of $75 \%$ of members of the House. Holyoake said he wanted "60 out of 80 members", meaning a House with a less than full attendance, voting on the bill, could make the job harder.
} 
House to carry out that mandate." ${ }^{140}$ In other words, the government's position was that a mandate from the public overrode the moral obligation of a government to reach consensus with an opposition. It was the government's extension of its 'mandate' argument that roused an opposition generally supportive of the changes into opposition mode.

In a sense, the government's argument rested on an assumption that a government elected on a manifesto including a change to the entrenched provisions was equal in 'moral' power to a simple majority gained in a referendum on the electoral laws - the other statutory way in which an entrenched provision could be changed. Opposition members rejected this logic, with many claiming the government had no mandate to change the law. ${ }^{141}$ Rather, the government had a "moral obligation" to "iron out differences." ${ }^{142}$ Like the Electoral Act 1956, and unlike most electoral legislation passed before 1965, the 1965 bill was sent to a select committee. The bill's referral to the Statutes Revision Committee was most likely governed by the government's need to gain opposition support in order to amend an entrenched provision. It was after the Committee reported back to the House that friction between the two parties became apparent. Indeed, in the Statutes Revision Committee, no suggestion was made or amendments moved by Labour members that the number of seats should be 26 instead of $25 .{ }^{143}$ In fact, the committee unanimously voted to send the bill back to the House without change. ${ }^{144}$

\footnotetext{
${ }^{140} 343$ NZPD 1718, 5 August 1965.

141343 NZPD 1664, 4 August 1965.

142343 NZPD 1671, 4 August 1965.

143343 NZPD 1794, 10 August 1965.

144343 NZPD 1794, 10 August 1965.
} 
Nonetheless, despite the report of the Select Committee, and primarily in response to what Labour members viewed as arrogance from the government, the opposition adopted the line that consultation on the Bill had not been sufficient. ${ }^{145}$ As the bill progressed through its readings, Labour's initial tacit support turned into deliberate obstruction. Numerous Opposition amendments were moved during the Committee stages to increase the number of seats to $26,{ }^{146}$ and to amend the Bill to increase Maori representation to five seats. ${ }^{147}$ The aim was to draw out the debate and slow down progress. Most of all, however, it was to make a point. Labour's aim was obstruction and protest at process rather than opposition to the bill itself. The fact that the government needed the opposition's votes to pass the legislation placed the opposition in a powerful position. The opposition was the result of tactics rather than an ideological divide.

The government's response was to attempt to call Labour's bluff; government members made repeated reference to the response of the electorate if Labour defeated the amendment. ${ }^{148}$ The bill was eventually read a third time under urgency and passed without a division being taken. ${ }^{149}$ While it did not vote against the bill, the opposition kept up its fight to the end. The Third Reading debate became so heated that Marshall forced a return to a committee stage so the Prime Minister could respond to what Hanan called a "cheap political stunt... intended to destroy the character and integrity of the Prime Minister." ${ }^{, 50}$ Labour MP (soon to be Labour leader) Norman Kirk's response was to again move an amendment to change 25 to $26 .{ }^{151}$ Overall, the

\footnotetext{
145343 NZPD 1816, 10 August 1965.

146343 NZPD 1711, 5 August 1965.

147343 NZPD 1972, 17 August 1965.

148343 NZPD 1972, 17 August 1965.

149343 NZPD 1767, 10 August 1965.

150344 NZPD 2729, 15 September 1965.

151344 NZPD 2728, 15 September 1965.
} 
debate ended up focussing more on what the bill did not include (26 seats and increased South Island representation) than anything else.

After 1965, the issue of a reduction in seats arose only once in prospective legislation. The Electoral (Reduction in Number of Members of Parliament) Amendment Bill 2006, a Private Member's Bill from New Zealand First MP Barbara Stewart, proposed reducing the number of MPs from 120 to 100. It was referred to the Justice \& Electoral Committee, although Labour (in government) voted against this happening. On report back from Select Committee, however, only ACT and New Zealand First supported the Bill. It was defeated.

\section{MP Qualification}

While the issues of term length and the number of MPs arose in a legislative context only on several occasions between 1927 and 2007, more frequent during the period were amendments to the laws that govern the requirements for a person to be eligible to serve as a Member of Parliament. Amendments to this area of the law have been made across the last eighty years. The Savage Government's Electoral Amendment Act 1937 included a provision that raised the deposit to stand as a candidate to $£ 10$. Both parties agreed on the measure, as, under FPP, vote splitting by minor candidates could affect the entire outcome of an election. National's Adam Hamilton wondered if $£ 10$ was high enough and whether a higher deposit would discourage people standing "merely for the sake of experience or for advertising themselves." ${ }^{152}$ In 1940, both parties combined to pass the Electoral Amendment Act 1940, which preserved the rights of MPs and Legislative Councillors serving in World War II to retain their seats in the respective chambers.

152249 NZPD 814, 30 November 1937. 
Under the MMP system, several bills, including one successfully passed into law, sought to tie individual Members of Parliament to the party on whose list they were elected. The earliest example of this was the Electoral (Party Registration) Bill 1997, an ultimately unsuccessful private member's bill in the name of Michael Cullen which sought to prevent 'party-hopping'. It was referred to the Electoral Law Committee but the government on the committee ensured a recommendation that the bill not proceed. All parties in the House voted against the bill, with the exception of Labour and the Alliance. Four years later, however, largely the same bill was enacted into legislation as the Electoral (Integrity) Amendment Act 2001. This Bill, introduced by Michael Cullen, attempted to prevent Members of Parliament from changing party while in the House. The House was split with Labour, Alliance and New Zealand First in support and National, ACT and the Greens opposed. The Select Committee was split evenly. The Bill passed over a year after it was introduced. It included a sunset clause (meaning the subsequent act would eventually expire) and ultimately expired. In 2005, as part of the Labour-led government's confidence and supply agreement with New Zealand First, the government introduced another attempt at a 'party-hopping prevention' law. It became clear that the government would not be able to pass the legislation due to the tight margins it was operating under, and the Bill lapsed after its referral to select committee.

One controversial aspect of the law dealing with the qualification for being an MP is the amount of retrospective legislation passed in this area. Between 1958 and 1963, several minor electoral amendment acts were passed exempting various Members of Parliament from disqualification under the Electoral Act 1956. Most related to a clause in the Electoral Act that automatically disqualified an MP who accepted fees from a government board in excess of $£ 200$. The first of these exemptions occurred in 
1958, when the Nash Government appended a clause to the Finance Act 1958, retrospectively saving William Fox MP from disqualification in respect of "any remuneration payable to him as a member of the Workers' Compensation Board in respect of any period before the first day of October $1958 " .{ }^{153}$ Fox, who was serving on the Board before the law was changed in 1956, consulted the previous National Attorney-General about the situation and was told everything was in order. When it emerged that the disqualification provisions did, in fact, apply to him, Nash consulted Keith Holyoake, then Leader of the Opposition, and inserted a clause in the Finance Bill to "put that matter right". ${ }^{154}$ Nash's consultation with the opposition before introducing the clause, combined with the circumstances of the law changing around Fox, rather than Fox directly contravening it, effectively removed the issue from partisan debate.

Later that year, Parliament passed the Electoral Amendment Act 1958 in an attempt to tidy up the ambiguity regarding MPs' earnings from outside politics. Introduced as part of a Statutes Amendment Bill, it made three small technical amendments to the definition of the term 'contractor' in the Electoral Act 1956. The Act set out a clear $£ 200$ limit for honoraria received for service on boards or in organisations. ${ }^{155}$ No debate arose on the measure which was passed alongside a number of other technical amendment acts. Despite the passage of the Electoral Amendment Act 1958, in 1960 the Nash Government included another clause in a Finance Bill that saved an MP from disqualification. Reginald Keeling MP had received funds from public money for attending an International Labour Organisation conference in Geneva and had unwittingly breached the Electoral Act. No major objection was raised by the

\footnotetext{
${ }^{153}$ Finance Act 1958.

154318 NZPD 1961, 23 September 1958.

155318 NZPD 2112, 30 September 1958.
} 
opposition but questions were raised by several National Members. ${ }^{156}$ Finance Minister Arnold Nordmeyer defended the government, saying that "[i]t is, of course, no new thing for the House to be called upon to validate payments of this kind made by the Crown to members of Parliament who are required by Government to undertake certain responsibilities." ${ }^{157}$ This was true: in 1958 the government had validated the payments made to William Fox. Yet that situation had been the result of the Electoral Act 1956 being passed during the MP's service on the board. Further, the Electoral Amendment Act 1958 had been intended to clarify the situation. In any case, no real objection was raised by the Opposition; the situation had been caused by an MP ignorant of the rules surrounding his qualification to sit in the House.

In 1961, the newly-elected National Government passed legislation to prevent a National MP from being disqualified in similar circumstances to Fox and Keeling. The government included in a Finance Act a similar provision to Labour's 1958 and 1960 Finance Act exceptions. The clause allowed William Brown MP protection from disqualification under the Electoral Act 1956, for honorarium received from a number of boards he had failed to resign from before he was sworn into Parliament. This was the third exemption clause inserted into a Finance Act since 1958. No debate arose on the matter. It was not until 1963 that the government made a statutory amendment to resolve what had become a recurrent issue. The Electoral Amendment Act 1963 further amended the troublesome clause of the 1956 Electoral Act to give an MP, upon his election to Parliament (and before being sworn in), one month in which to disclaim the contract and any payment made after that disclamation. The bill received no debate or objection from the opposition and was passed without any

\footnotetext{
156325 NZPD 3200, 21 October 1960.

157325 NZPD 3200, 21 October 1960.
} 
division. The next and final time a similar issue arose during the period studied was in 2003, which saw the passage of the first piece of retrospective legislation to excuse an MP from disqualification since the Finance Act clauses passed by Labour and National governments in the late 1950s and early 1960s. Harry Duynhoven, a government Minister, had been automatically disqualified from Parliament after applying for Dutch citizenship. The government claimed the law was unclear and introduced retrospective legislation to exempt him from disqualification. Roger Sowry, a National Member, called the bill "a cynical manipulation of Parliament... to

allow a member who has broken the law to get off that breaking of the law". 158 National also accused the Speaker of deliberately delaying declaring Duynhoven's seat vacant so that the bill might pass the House. Labour, the Greens, United Future and Progressives voted for the Bill. The Spaker, Jonathan Hunt, abstained. It passed all of its readings in one night. The following year, the Electoral Amendment Act 2004, legislation only "reluctantly supported" by National, made a number of technical changes to the Electoral Act as well as clarifying the situation regarding dual citizenship that had seen Harry Duynhoven disqualified and saved the previous year.

\section{Election of MPs and the Post-Election Period}

It remains in this chapter to examine the legislation pertaining to the election of Members of Parliament and post-election processes. While the focus of this thesis does not include broader constitutional matters such as the 1950 abolition of the Legislative Council, as established in chapter two, the electoral law forms part of the New Zealand constitution. Generally, throughout the 80 years studied, Parliament was unwilling to interfere with the multitude of conventions that govern the post-

${ }^{158} 610$ NZPD 7709, 6 August 2003. 
election process in New Zealand. The first example in Hansard is an ultimately unsuccessful Electoral Amendment Bill introduced by Labour Member Jonathan Hunt in 1976. This bill proposed lengthening the parliamentary session by requiring it to sit no later than 90 days after the return of the writs following an election. The bill also attempted to even out the House's sitting schedule - to make it sit 90 days a year (three days every three weeks of every month). Other provisions extinguished the Governor-General's powers to prorogue or dissolve Parliament without an absolute majority of the House - no doubt a reaction to the constitutional crisis in Australia. Much of the material in the bill was first suggested in the 1975 report of the Select Committee on the Electoral Bill. National had come to power in the interim. In addition to the Australian influence, the primary purpose of the bill - to call the House into session early - was driven largely by Labour's reaction to Muldoon's decision to suspend contributions to the Rowling Government's superannuation scheme by decree, when legislation was in fact required to do so. ${ }^{159}$ Labour also hoped all the essential parts of New Zealand's unwritten constitution could be consolidated in one act, which could be widely distributed amongst the public to inform them of their voting rights. ${ }^{160}$ National argued that the clauses regarding the Governor-General's ability to dissolve Parliament removed a "substantial safeguard for the people." 161

The debate also saw an interesting development of the 'mandate' argument. The government argued that, even though Labour had lost the election and there was no real prospect of Hunt's bill passing the House, as Labour had not signalled the

\footnotetext{
159 The decision was subsequently declared illegal in one of New Zealand's most famous cases. See Fitzgerald v Muldoon [1976] 2 NZLR 615.

160403 NZPD 688, 16 July 1976.

161403 NZPD 797, 16 July 1976.
} 
proposed changes in its 1975 election manifesto, it breached convention for the bill to have been introduced. ${ }^{162}$ The government did not oppose the bill's introduction "as a matter of courtesy", ${ }^{163}$ and it was struck off the order paper on 25 August, after its second reading, as the Speaker declared it involved an appropriation. ${ }^{164}$ The next electoral related constitutional issue to arise in a legislative context was the Electoral Amendment Bill 1986, split from the Constitution Bill 1986 on its third reading. The Act clarified the rules relating to transfer of power after an election in the light of the constitutional issues raised when Muldoon left office in 1984. No new electoral material was included and the bill passed with the support of the National Opposition.

While Parliament exhibited reluctance to legislate on electoral-related constitutional issues between 1927 and 2007, legislation proposing changes to the electoral system was more abundant, although most of it was unsuccessful and introduced in Private Members' Bills. In fact, the only successful electoral system change was the Electoral Act 1993, discussed in chapter three, which ushered in the MMP electoral system. Nonetheless, during the operation of the First Past the Post system, a number of private member's bills were introduced attempting to change the system in some respect. There is record in Hansard of James McCombs, Labour MP for Lyttelton, introducing a Preferential Voting Bill as a Private Member's Bill in 1929. No more is known about it; it received no introductory statement from its mover or subsequent debate and lapsed at the end of the term. McCombs was constrained by the Standing Orders of the time from speaking on the first reading, which traditionally was not an occasion for debate. This is a common problem in analysing a number of electoral amendment bills introduced in the early 1930s.

\footnotetext{
162404 NZPD 799, 21 July 1976; 403 NZPD 692, 16 July 1976.

163404 NZPD 788, 21 July 1976.

${ }^{164} 405$ NZPD 2006-07, 25 August 1976.
} 
In the early 1930s, Cecil Clinkard, a Coalition Member of Parliament, twice attempted to alter the voting system to a simple form of STV. His 1931 Private Member's bill garnered no reaction from the opposition or his colleagues - he was the only one to speak to the bill's introduction. ${ }^{165}$ It never progressed past its first reading. Apparently undiscouraged, in 1934 Clinkard re-introduced "a measure... identical with one which I introduced four years ago but which, unfortunately, went to the bottom of the Order Paper." 166 The only other MP who rose to speak was Peter Fraser, "merely... to express the opinion that if the honourable gentleman wanted to get opposition to his Bill he has gone the right way about it with the oblique style of reasoning he has indulged in." 167 The bill, again, lapsed at the end of the session. Alongside Labour Member of Parliament Gerry Wall in the late 1970s, and whose prolific legislative efforts are examined in chapter six, Clinkard exemplifies the most active of a number of MPs who have introduced often quite complex changes to the electoral law through private members' bills with no real chance of succeeding. The purpose of these bills was often to raise the profile of the issue involved or, in Wall's case, attack the government by proposing a remedy or multiple remedies in order to point out defects. Having been defeated four times in his attempts to introduce legislation amending enrolment provisions, in 1980 Gerry Wall turned his attention to a private member's bill proposing that, if an MP failed to be elected by a majority, a second ballot would be held the following Saturday between the top two candidates. The bill was defeated on introduction.

\footnotetext{
165228 NZPD 10, 26 June 1931.

166238 NZPD 102, 3 July 1934.

167238 NZPD 103, 3 July 1934.
} 
In the wake of the report of the Royal Commission on the Electoral System, and after the National Party announced it would pursue electoral reform as a priority, a number of private member's bills were tabled between 1990 and 1993 seeking to force an early referendum so a new electoral system could be in place for the 1993 General Election. The first was the Proportional Representation Indicative Referendum Bill 1990, introduced by Labour Member John Terris in the final days of the fourth Labour Government. It sought to hold a referendum on the introduction of MMP. For the first time on an electoral issue in New Zealand, opinion on the Bill was split along conscience rather than Party lines. The Bill was introduced 49 votes to 19 and referred to the Electoral Law Committee. It eventually lapsed after the report of the Select Committee and a brief second reading. Then NewLabour MP, Jim Anderton, made two attempts to introduce a bill that sought to hold a referendum on the introduction of MMP. His first attempt, the Mixed Member Proportional Representation Poll Bill 1990, was defeated on its introduction by a conscience vote. His second bill was introduced and read a first time in 1992. There was no division and the bill was referred to the Electoral Law Committee. The bill lapsed after it was referred; the committee did not report back in time for the 1993 General Election.

The Electoral Referendum Act 1991, introduced as the Electoral Poll Bill, set the stage for one of the most significant constitutional changes in New Zealand's history. It formed two parts: first, whether a change should be made from FPP and second, to what that change should be. The referendum was indicative only. The bill was introduced and referred to the Electoral Law Committee, which both sides agreed debated the issues in a non-partisan manner and came up with a solution agreed upon 
by all sides. ${ }^{168}$ The Bill was read a second time under urgency (unopposed); it completed its committee stages and third reading with no division or further debate. The result of the referendum, held in 1992, led to a second referendum at the 1993 General Election where voters were asked to choose between First Past the Post and Mixed Member Proportional. The result changed the course of New Zealand's electoral history. In terms of legislation, only one attempt to provide for a further referendum on MMP was made after 1996. The Electoral Options Referenda Bill 2002 was a private member's bill placed in the ballot by Jenny Shipley and transferred to Simon Power after her departure from Parliament. It proposed two referenda on the electoral system. The government opposed the bill and it was defeated on its first reading. ${ }^{169}$

It remains to mention by-elections. On a number of occasions, Parliament legislated to postpone by-elections - usually caused by the death of a member - until a General Election. The first of these acts was the By-elections Postponement Act, passed unanimously in 1943, which followed the Prolongation of Parliament acts, passed in 1941 and 1942 due to World War II. No debate arose on the matter. Parliament again delayed by-elections in 1969 with a General Election looming. The government consulted with the leader of the Labour Party and the Leader of Social Credit before introducing the bill. Thus it was passed unanimously and without a great deal of debate. ${ }^{170}$ Likewise, in 1987 , legislation was passed to prevent any seat which became empty before the general election from being filled before the general election in a by-election. It was unopposed and did not garner much debate. Legislation pertaining

\footnotetext{
${ }^{168}$ See 521 NZPD 5996-98.

169 At the time this thesis was completed in 2009, indications were that the National Government would follow through on its 2008 election promise of holding a referendum on the MMP system at the 2011 General Election.

${ }^{170} 362$ NZPD 2592, 5 September 1969.
} 
to by-elections is a rare area of the electoral law that saw unanimous consent throughout the 1927 to 2007 period.

This section has covered areas of New Zealand's electoral law that affect the election of Members of Parliament and the functioning and structure of Parliament itself. Even in these areas alone, it is evident that amendment of the electoral law in New Zealand is distinct not only in the wide variety of the scope and import of the changes made by various governments, but in the range of ways in which governments have gone about making the changes and the attitude and response of oppositions to amending the electoral law. This chapter has covered both controversial and non-controversial changes. Chapter five now turns to two almost wholly controversial areas - franchise and electoral boundaries. 


\section{Chapter Five Boundaries, Franchise and Registration}

Electorate boundaries and matters concerning franchise and registration - the law relating to who can enrol to vote and how they are able to do so - were major causes of conflict between governments and oppositions between 1927 and 2007. This chapter examines both areas, beginning with the Electoral Amendment Act 1945, which abolished the country quota.

\section{Boundaries and Representation Commission}

The 1945 Electoral Amendment Act, which altered the formula by which electorate boundaries were calculated, stands as a significant moment in the history of New Zealand's electoral law. If 1932 and 1934 were the times the Labour Party protested against the government's 'unconstitutional' and 'immoral' alteration of the electoral law, 1945 saw the tables turn. Indeed, the Fraser Government's move to abolish the country quota, alter the composition of the Representation Commission to include government appointees and alter the basis by which boundaries were calculated from total population to adult population, caused one of the most exhaustive and acrimonious debates over electoral law in New Zealand's history. The level of dissent from the opposition would not be seen again until the debate over the Electoral Amendment Bill 1975.

Setting aside a retrospective historical position which sees the country quota primarily as inequitable, the country quota had in 1945 formed a part of the New Zealand political system for decades. The fact it gave an inherent advantage to the party strongest in the provinces (the National Party) was the reason behind the 
acrimony of the debate. The Electoral Amendment Act 1945 is unusual in the sense that there was no dispute that, in electoral terms at least, the National Party Opposition stood to lose from its passage and the Labour Government stood to gain. The government offered little defence of the bill during the debate, other than pointing out the electoral inequities generated by the country quota and the advantages conferred on the Opposition by the operation of the quota. Some government members linked the government's move to the broader international efforts Fraser was making at the time. Dr Sullivan, Minister of Industries and Commerce, for example, claimed the bill was an indication of the government's "faithfulness to the cause and principles of democracy in lining itself up with the other democracies of the world..."171

Opposition in the House followed the same lines of argument used by the Labour Opposition against the Electoral Amendment Bill in 1934. The major charge against the government was that of self interest. Speaking in the debate on the first reading of the Bill (an unusual move at the time, and forced by the opposition), ${ }^{172}$ the bill was variously described by opposition members as "a piece of political trickery, done to save the Government's own skin", ${ }^{173}$ the "Socialists' Security Amendment Bill", ${ }^{174}$ and the work of the "Incorporated Society of Opportunists". ${ }^{175}$ The height of the acrimony occurred when Matthew Oram, later Speaker of the House, said he believed the "nefarious Bill will take its place in history, along with the burning of the Reichstag, as one of the great political crimes of history." ${ }^{176}$ Even the usually sedate

\footnotetext{
171270 NZPD 677, 18 October 1945.

${ }^{172}$ Sidney Holland recalled it was 15 years since a similar debate on a first reading had occurred. (270 NZPD 768, 25 October 1945)

173270 NZPD 684, 18 October 1945.

174271 NZPD 110, 1 November 1945.

175270 NZPD 765, 25 October 1945.

176271 NZPD 120, 1 November 1945.
} 
and ineffective Legislative Council sprung into life in its debate on the bill, although its deliberations lacked the acrimony of the debates in the House. ${ }^{177}$ The government was not helped by statements from several of its members that suggested self-interest was, indeed, a motive. One Labour MP said "[t]he Labour party does not require the assistance of the country quota, either to win or retain power in this House." 178 Holland quoted an issue of the Labour Party newspaper, The Standard, which carried a speech from a Labour Member who said: "We will fix [the Opposition] with our new legislation. We will put all the coffin nails in them before long."

The criticisms made of the 1945 Act did not only concern substance, but also process. Chief among the criticisms were the government's failure to notify the opposition of its intention to introduce the bill, ${ }^{180}$ and its use of urgency to pass the bill through most of its stages. ${ }^{181}$ The bill received its third reading at 3:28am on a Saturday morning, three and a half hours after the parliamentary broadcast had finished. ${ }^{182}$ Keith Holyoake set out the problem that would have most concerned the government, whatever its motives: ${ }^{183}$

The sporting spirit of our people will be outraged to such an extent that the mathematical advantage the Government hopes it will gain will be more than outweighed by that revulsion of feeling... I am confident that there will be a revulsion of feeling not only against the Bill itself, but against the methods adopted by the Government in introducing it.

177271 NZPD 214, 6 November 1945; 271 NZPD 318, 8 November 1945; 271 NZPD 348-49, 8 November 1945.

178270 NZPD 685, 18 October 1945.

179270 NZPD 769, 25 October 1945.

180270 NZPD 673, 18 October 1945.

181270 NZPD 784, 25 October 1945. Notably, in the recent example of the Clark Government's Electoral Finance Act 2007, the Government brought the House out of urgency for the bill's third reading.

182271 NZPD 172-73, 2 November 1945.

183270 NZPD 675, 18 October 1945. 
Perhaps the most important factor in the way a government's changes to the electoral law are perceived by the public is the process by which it goes about changing the electoral law. The second argument made against the bill by the opposition was that the government had no mandate to pass the legislation. This had been the most potent argument made against the Coalition's term-extension legislation a decade earlier, and was again the strongest criticism on this occasion. The government had not signalled in its 1943 election manifesto that it intended removing the country quota. Indeed, it had made a pledge that it would not remove the quota until a conference of the Labour Party had decided on the move and it had been put to the electorate. ${ }^{184}$ This served merely to compound the accusations of self-interest being levied against the government.

In response, Holyoake set out the doctrine that would later sit at the centre of National Party's electoral reform programme throughout the 1950s and 1960s when he said that, "[w]hen we amend the Constitution of the country it should be done only after reference to the electors and with the approval of the majority of the electors. The Government has no such mandate." ${ }^{185}$ Indeed, to summarise the content of opposition criticism on this point it is worth quoting in full a contribution to the debate made by Josiah Hanan in the Legislative Council. ${ }^{186}$

In discussing this Bill and its merits or demerits, all consideration for party interest, and all regard for the instinct of party preservation, should be swept aside. We should consider this Bill as from a referee's viewpoint. As referees, we are not concerned as to whom wins the game or the contest, but to see that the rules of the game are observed faithfully and strictly. I have always held - and so have all true Democrats - that before legislative enactments become law, there is demanded for their realization democratic methods and the consent of the people, from whom Governments derive all power.

\footnotetext{
184270 NZPD 672, 18 October 1945.

185270 NZPD 674, 18 October 1945.

${ }^{186} 271$ NZPD 309-310, 8 November 1945.
} 
The Electoral Amendment Act 1945 serves as an important point in the amendment of the electoral law. Although the principles outlined in opposition to the legislation would not be put into practice until 1956, it is arguable that the approach of future National Party Ministers such as Keith Holyoake, Jack Marshall and Ralph Hanan developed in reaction to the 1945 bill. Perhaps a corollary of the controversial nature of the Electoral Amendment Bill and the process by which it was passed, the debate also provides the first example in the two-party system of an Opposition adopting tactics to obstruct the debate and create publicity over a piece of electoral legislation. National did "everything within [its] constitutional powers" to halt the bill. ${ }^{187}$ National members moved amendments attempting to introduce a referendum on the contents of the bill. ${ }^{188}$ Numerous amendments were proposed during all stages, ${ }^{189}$ and multiple attempts were made to refer the Bill to a select committee for consideration. ${ }^{190}$ Even Peter Fraser recognised the extent of the opposition put up by the National Party: "I have nothing but respect for those people who believe that the step taken by the Government is wrong and who have opposed it to the full limit of the rules of the House." 191

In 1950 the new National Government led by Sidney Holland reversed some of the changes made by the Fraser Government five years earlier. Primarily, the Act returned the population basis used for boundary calculations to total population from adult population, a change made by the 1945 Act. The government made no attempt to bring back the country quota. The quota was, like the Legislative Council which the National Government abolished in 1950, easily abolished but not so easily

\footnotetext{
187271 NZPD 160, 2 November 1945.

188270 NZPD 769, 25 October 1945; 271 NZPD 135, 1 November 1945.

189271 NZPD 143, 2 November 1945.

190271 NZPD 143, 1 November 1945.

191271 NZPD 171, 2 November 1945.
} 
brought back. In any case, the government may have faced a backlash from the urban electorates had it sought to bring back the quota which, in 1943, gave 9592 electors in Egmont the same voting power as 24513 in Remuera. ${ }^{192}$ The 1950 debate lacked the acrimony or intensity of the 1945 abolition debate. The changes proposed by the government had been well-signalled in National's election manifesto. National members had promised to repeal the 1945 legislation ever since it was passed. While the opposition characterised the change from adult population back to total population as a 'form of country quota', the fact the government did not attempt to bring back an actual country quota blunted the attacks on the bill. Nor was the opposition able to claim an abuse of process. While the bill passed by a simple majority with the opposition voting against it on its second and third readings, there was a grudging acceptance that the government had the mandate to make its changes.

The National Party had explicitly set out its intentions regarding the Electoral Act in its 1949 election manifesto. ${ }^{193}$ The government did not expect its changes to receive bi-partisan support. Its mandate came from its election. One government member said "I am amazed that the attack on this Bill has been so weak... I would like an Opposition member to get up and condemn the measure, if he can." ${ }^{194}$ Ultimately, the 1950 debate would be the last decidedly partisan debate on an electoral issue for two and a half decades.

As in the electoral amendment act debates of 1934 and 1945, self-interest was the major accusation levelled by the opposition at the government. Labour members called the changes "a country quota in modified form" and argued the government

\footnotetext{
${ }^{192}$ Atkinson Adventures in Democracy, p. 157.

193291 NZPD 2738, 27 September 1950.

194291 NZPD 2749, 27 September 1950.
} 
had introduced the bill for its own political advantage, ${ }^{195}$ and to "foster its political fortunes." ${ }^{196}$ For its part, the government argued the changes did not favour it to any "material extent". ${ }^{197}$ Furthermore, its opposition to the changes made in 1945 had been consistent; it was not seeking to restore the country quota, had signalled its intention to introduce the bill and was introducing the bill at the beginning of its term. These factors blunted the opposition's attacks. Interestingly, the fact that the government was not seeking to restore the country quota was not raised in the House debates. The fullest examination of this point came, ironically, in the Legislative Council, which had been impotent over the Electoral Amendment Act 1945 and was about to be abolished. Mr Polson, the Leader of the Council, underscored the reasoning behind the government's decision on the country quota: ${ }^{198}$

I am not defending the country quota in what I shall have to say. Possibly the time has gone by for the country quota, and with the advance of democratic thinking, but certainly the time has not gone by for giving adequate representation to the population who dwell in the country.

The Bill received its first, second and third readings in the Legislative Council with no divisions. ${ }^{199}$ The amendment was the last piece of electoral legislation the Legislative Council would debate. After the passage of the 1950 Electoral Amendment Act, the issue of the country quota faded into history, as did the Legislative Council. The level of acrimony that arose during the debate would not be seen again until the 1970s.

\footnotetext{
195291 NZPD 2670, 26 September 1950.

196 291 NZPD 2835. 29 September 1950.

197291 NZPD 2737, 27 September 1950.

198291 NZPD 2831, 28 September 1950.

199291 NZPD 2761, 27 September 1950; 291 NZPD 2905, 3 October 1950; 291 NZPD 2956, 4 October 1950.
} 
Other matters relating to electoral boundaries and the Representation Commission proved a source of controversy over the years. Another aspect of the Electoral Amendment Act 1945 that raised virulent opposition was the Act's alteration of the composition of the Representation Commission. While retaining several impartial appointees, such as the Surveyor-General, the legislation allowed the government to appoint a majority of the nominees, giving government appointees an effective veto on the committee. The opposition received no representation. As outlined in chapter three, the Electoral Act 1956 settled this situation by providing for both government and Opposition representation on the Commission. The first time the 1956 arrangement was challenged was in 1978, when Social Credit's Bruce Beetham introduced a Private Member's bill to place representatives from Social Credit and the Values Party on the Commission. The bill also contained a provision that any party enjoying support from at least five percent of the population would be represented on the Commission. Beetham's bill, which affected an entrenched provision, never had any chance of passing but was intended to make a point about third party representation on the Electoral Commission and, indeed, in Parliament. The bill was introduced and read a first time without a division, ${ }^{200}$ and Beetham used his introduction speech to argue that the major parties were unfairly influencing boundaries. ${ }^{201}$ Both Labour and National Members opposed the Bill, calling it an "exercise in futility"202 and badly-timed, ${ }^{203}$ although Hunt supported Beetham to an extent when he said that Beetham had raised a point that "cannot be ignored."204 Bill Birch claimed, rather unbelievably, that "never has it been suggested that boundaries

\footnotetext{
200418 NZPD 1557, 5 July 1978.

${ }^{201}$ Six years later, Beetham was to lose his seat owing partially to boundary changes.

202418 NZPD 1551, 5 July 1978.

203418 NZPD 1551, 5 July 1978.

${ }^{204} 418$ NZPD 1723, 12 July 1978.
} 
were altered to suit political parties. ${ }^{205}$ Beetham's bill served to unite the government and opposition against a common target: a third party. As Beetham said: ${ }^{206}$

I have found it somewhat amusing that on one aspect of electoral matters, namely the state of the rolls, members on both sides of the House are to a man utterly opposed to each other, but on another aspect, namely my Bill, both sides of the House are utterly united in opposition, in preservation of their vested interest in the entrenched status quo.

The Electoral Amendment Act 1981, introduced by the National Government, made substantial changes to the Representation Commission. Social Credit had been represented on the Electoral Law Committee and the Act as passed provided for the Representation Commission to invite submissions from any political party or independent MP without an official representative on the Commission. This concession to the minor party was agreed in the Select Committee. The Act also required the Representation Commission to publish the objections it had received to provisional boundaries and allow a period for the lodging of counter-objections. The bill received its third reading without a division. It was agreed that "no really dramatic changes" were ordered by the 1981 Bill. $^{207}$ The small concession to Social Credit was, however, not enough for the party. In 1986, NZDemocrats (the successor to Social Credit) MP Garry Knapp introduced a Bill seeking to "allow the participation of all bona fide political parties in the process of setting electoral boundaries." ${ }^{208}$ National and Labour were again united against the bill and it was defeated on introduction. The final attempt in the period studied to change the Commission to alter the position of third parties was a 1994 bill introduced by Jim Anderton. The bill sought to do the opposite to the Social Credit and NZDemocrats

\footnotetext{
205418 NZPD 1553, 5 July 1978.

206418 NZPD 1721, 12 July 1978.

207441 NZPD 3775, 30 September 1981.

208470 NZPD 1223, 23 April 1986.
} 
bills and, instead, remove all political representation from the Commission. While the government indicated it did not support the bill, it was introduced and referred to the Electoral Law Committee and ultimately lapsed. It is perhaps surprising that a similar member's bill was not introduced by a minor party in the period between 1994 and 2007. As at 2007, the National and Labour Parties were represented on the Commission, but small parties were not.

While governed by the Electoral Act 1993, the Commission as it stood in 2007 was shaped primarily by the Electoral Amendment Act 1991, introduced by the National Government led by Jim Bolger. That Act made a number of changes to the composition and procedures of the Representation Commission, in line with the recommendations made by the Electoral Law Committee in 1988 in its report on the 1987 general election and the recommendations of the 1986 report of the Royal Commission on the Electoral System. These included adding a Maori representative for both the National and Labour Parties, and allowing parties that received over five percent of the vote to make submissions.

The government was required to seek consensus on the changes, as many of them affected an entrenched provision of the Electoral Act 1956. The Opposition pledged its support at the outset. The Bill was passed without division. The debate was notable as it saw a number of National Party Members affirm the importance of the bi-partisan approach to electoral reform, particularly in the lead-up to the referenda of 1992 and $1993 .^{209}$ From acrimonious beginnings, by the end of the century, consensus emerged between the two major parties on boundaries.

${ }^{209}$ See, for example, National MP Murray McCully; 516 NZPD 2639, 25 June 1991. 


\section{Franchise and Registration}

Issues of voter franchise and registration also saw their share of controversy over the 80 year period studied. In the late 1960s and early 1970s, the age of eligibility to vote was a source of contention between the National and Labour parties.

In 1969, the Holyoake Government introduced a bill to lower the voting age from 21 to 20. The Electoral Amendment Bill 1969 was introduced at the same time as a bill lowering the drinking age from 21 to $20 .^{210}$ Advocates for lowering the voting age were found in both the National and Labour parties, ${ }^{211}$ although the Labour Party had been in favour of lowering the voting age for longer than National. In 1969, however, both parties were united on the desirability of doing so, if not on the specific age.

The disagreement took place on an ancillary matter; Labour believed the bill did not go far enough and that the voting age should be lowered to 18. Its argument was bolstered by a petition received by the Petitions Committee, and signed by 11,000 people, praying for an amendment to lower the voting age to 18 years. ${ }^{212}$ The government was not prepared to entertain this suggestion and, while Labour members ultimately voted for the age to be lowered to 20 , they maintained throughout the debate that it should stand at 18. The opposition also criticised the government's timing, arguing that the bill should have been introduced much earlier. Kirk accused National of attempting to win the next election by expanding the voting franchise just before the election, although he admitted at the same time that he believed Labour would benefit more than National from the addition of younger voters. ${ }^{213}$

\footnotetext{
${ }^{210}$ Sale of Liquor Amendment Act 1969.

211 Barry Gustafson, Constitutional Changes Since 1970. Auckland, Heinemann Educational Books, 1969 , p. 38.

${ }^{212}$ Report of the Petitions Committee [1969] AJHR I.1.

${ }^{213} 362$ NZPD 1724, 5 August 1969.
} 
Nevertheless, the government and opposition were in agreement on the bill and the Labour opposition supported an urgency motion to pass the bill, which occurred without the taking of a division.

In 1972, during the final days of the National Government, Labour's Colin Moyle introduced an ultimately unsuccessful Member's bill which sought to lower the voting age to 18 years and allow the Chief Electoral Officer to actively enrol people to vote. While the Labour Party supported the Bill (and, indeed, passed a similar bill when it assumed government soon after), the National Party Government did not officially support the further lowering of the voting age. It was a debate the government did not want to have in the lead-up to the 1972 election and attempts were made to keep the Bill down the Order Paper. Indeed, Moyle stated at the outset that "[t]he Government has done everything in its power to keep [the bill] out."214 There had, however, been support within National for lowering the voting age to 18 . A remit passed by the Auckland conference of the National Party had been narrowly defeated at the Dominion Conference that year. ${ }^{215}$ Muldoon even stated that he found himself "substantially in agreement with most of things that [Moyle] said, although that agreement did not go quite far enough to persuade me that his Bill is one that should be supported at present." 216

National's primary argument against the Bill was that it would necessarily lead to the age for other things being lowered to 18 as well. This, Muldoon said, would pose difficulties for acts such as the Domestic Proceedings Act, the Guardianship Act and the Apprentices Act, the Juries Act and the Marriage Act. Labour Member Jonathan

\footnotetext{
214379 NZPD 1327, 28 July 1972.

215379 NZPD 1329, 28 July 1972.

216379 NZPD 1328, 28 July 1972.
} 
Hunt countered that Great Britain, the United States and most states of Australia had already lowered the voting age to $18 .^{217}$ The issue was simply one in which a breach existed between the thinking of most National members and most Labour members. The Bill was read a first time but the government prevented it from being referred to the Statutes Revision Committee. ${ }^{218}$ While it received a second reading, the Speaker first ruled it out of order as involving an appropriation. ${ }^{219}$ Continuing a theme raised throughout debates on the electoral law, some accusations of self-interest were levelled. There was some discussion during the second reading debate about which party would benefit most from the bill; National Member Dan Riddiford claimed that National would benefit most. ${ }^{220}$ Whatever the parties' perceptions, there is no direct evidence that Labour gaining more votes was one of the party's motivations behind introducing the bill, nor one of National's in opposing it. For Moyle, the proposal was about "com[ing] into step with the realities of the 1970s."221

Labour went into the 1972 General Election with a pledge in its manifesto to lower the voting age to 18. The Electoral Amendment Act 1974 fulfilled the promise. Surprisingly, perhaps, after its opposition to Moyle's member's bill in 1972, National offered practically unreserved support to the Electoral Amendment Bill. It could have blocked the bill if it had wished; the bill affected the entrenched provisions of the 1956 Act and required 75 percent support. Part of National's willingness to accede so readily to lowering the voting age to 18 (gone were all of its previous objections) was the death of Prime Minister Norman Kirk, who had died two and a half weeks before the Bill's introduction. Obstructing the passage of a bill aimed to apply to his

\footnotetext{
217379 NZPD 1337, 28 July 1972.

218379 NZPD 1388, 1 August 1972.

219379 NZPD 1673, 9 August 1972.

220379 NZPD 1688, 9 August 1972.

221379 NZPD 1697, 9 August 1972.
} 
Sydenham by-election (in which National ultimately did not stand a candidate) would have been politically counter-productive. As Martyn Finlay, Minister of Justice, said during the Bill's introduction: ${ }^{222}$

The reason for [introducing the bill] on this day and at this time is the unfortunate necessity to hold a by-election in Sydenham. A Bill of this nature would certainly have been introduced before the expiration of this Parliament, and in adequate time for the purpose of the Bill to be given effect to. It is unfortunate that we must do this in a rather more hurried manner than we would have wanted, and because of that I invite the House to give the Bill rather more expedition than normally attached to legislation.

Nonetheless, the government still consulted with the opposition - although, in effect, it had to because of the entrenched provisions - and an informal agreement was reached. The bill had also been debated in a select committee in the week before its introduction. ${ }^{223}$ On 17 September, the Electoral Act Committee, chaired at that stage by Hunt, recommended unanimously that the voting age be reduced to 18 years. ${ }^{224}$ The bill passed its second and third readings the next day, unamended, with National offering no objection or debate. ${ }^{225}$ From 1974, consensus existed between the two major parties that the voting age sits at an appropriate level.

\section{Enrolment and Eligibility to Vote}

In 1966, the newly re-elected Holyoake Government introduced what appeared to be a simple and non-controversial electoral amendment bill. The Electoral Amendment Bill 1966, however, was a rare example of a government electoral bill failing in the House. It was also significant because the cause of that defeat was the entrenchment provisions of the Electoral Act 1956 - the first time entrenchment had prevented a government from changing the electoral law.

\footnotetext{
222394 NZPD 4266, 18 September 1974.

223394 NZPD 4268, 18 September 1974.

${ }^{224}$ Interim Report of the Electoral Act Committee, [1974] AJHR I.15.

225394 NZPD 4369, 19 September 1974.
} 
The bill contained only one clause, providing that servicemen under 21 years of age would be qualified to vote at a general election if they are serving overseas in a special area, the latter term being defined by Order-in-Council. ${ }^{226}$ As was the case with the government's 1965 Electoral Amendment Act, which also amended an entrenched provision, the 1966 bill was referred to a select committee so that the necessary consensus could be attained for its passage through the House. The Statutes Revision Committee heard representations from eight different sources but only one the Returned Servicemen's Association - offered support. The Constitutional Society and the Public Service Association opposed the bill, ${ }^{227}$ and several government members on the committee indicated opposition to it. ${ }^{228}$ While several amendments were agreed on in the committee, it was obvious when the bill was reported back that it would not pass. Labour members argued the bill remained too selective and technical, ${ }^{229}$ and Kirk said that it was "riddled with inconsistencies... a measure which has been promoted essentially for political and emotional purposes. ${ }^{230}$ Realising the bill would probably not pass, Labour turned the committee report debate into a debate about lowering the voting age across the board. ${ }^{231}$ The debate was interrupted for the dinner break on 14 July and never resumed. ${ }^{232}$

While in the case of the Electoral Amendment Act 1965 the government was able to use the power of its mandate and the fact both parties were agreed in substance on the content of the bill to amend the entrenched provisions of the Electoral Act 1956, 1966

\footnotetext{
${ }^{226} 346$ NZPD 390, 10 June 1966.

227347 NZPD 1415, 14 July 1966.

228347 NZPD 1415, 14 July 1966.

229346 NZPD 391, 10 June 1966.

${ }^{230} 347$ NZPD 1420, 14 July 1966.

231346 NZPD 1426, 10 June 1966.

232346 NZPD 1434, 10 June 1966.
} 
presents a converse situation. In this case, entrenchment prevented the government from making a change that, while minor, did not have the support of the House, even after the government had engaged with the opposition to try to reach consensus.

After the passage of the Electoral Amendment Act 1975, which made substantial changes to franchise and registration requirements and was discussed in length in chapter three, the National and Labour Parties generally divided over the issue of the day on which the electoral roll enrolment closes and the residential requirements for enrolment. In 1977 the Muldoon Government fulfilled National's pledge during the 1975 Act debate, and 1975 election manifesto, that it would repeal the sections of the 1975 Act with which it disagreed. ${ }^{233}$ The most significant changes made by the 1977 Act involved the two contested amendments made in 1975. The 1977 Act reverted to the pre-1975 status quo the provision that anybody qualified to vote but who had not registered could vote. The time required to be resident in an electorate returned to three months from one month. Labour called the move "a massive tightening" that would "disqualify up to 100,000 New Zealanders in the next election."234 The franchise was also removed from prisoners.

Much of the 1977 bill was debated under urgency, a move criticised by the Opposition. ${ }^{235}$ The procedure through which the bill was passed caused equal opposition from Labour as did the bill's content. The House divided on party lines to introduce the bill and refer it to the Statutes Revision Committee. Jim McLay, as chair, arranged for the secretary of the Statutes Revision Committee to contact those who had made submissions to the previous select committee on matters covered by

\footnotetext{
${ }^{233} 415$ NZPD 4157, 3 November 1977.

${ }^{234} 415$ NZPD 4552, 17 November 1977.

235416 NZPD 5155, 7 December 1977.
} 
the 1977 Bill to see if they wished to be heard again. ${ }^{236}$ He also invited the Social Credit and Values Parties to make submissions and provided copies of the bill to them. Values made submissions and its secretary appeared in support. ${ }^{237}$ In all, five substantive submissions were received.

Yet this initial move to consult widely with the public was constrained by the time limits imposed by the government on the Committee's work. Submissions opened on 4 November and closed on 16 November, giving less than two weeks in which to make a submission. ${ }^{238}$ The time frame led Labour Member of Parliament, Richard Prebble, who served on the select committee, to call it "one of the worst abuses of the parliamentary system I have seen."239 Ultimately, questions of both process and content divided the Committee. And the bill was reported back without amendment. $^{240}$ As McLay said: ${ }^{241}$

[T] here are strong differences of opinion between members on each side of the House as to the necessity for these changes, and these divisions were reflected in the discussions, debate, and voting during the select committee's deliberations.

The Labour Opposition agreed that these problems had occurred, but wished the relevant provisions could have been amended "in a progressive manner rather than in the negative way the government has chosen to adopt."242 This accusation emphasised the difference in approach between the government and opposition. National saw the pre-1975 status quo as preferable; Labour saw the steps it had

\footnotetext{
${ }^{236} 415$ NZPD 4551, 17 November 1977.

237415 NZPD 4550-51, 17 November 1977.

${ }^{238} 415$ NZPD 4552, 17 November 1977.

${ }^{239} 415$ NZPD 4552, 17 November 1977.

${ }^{240}$ Report of the Statutes Revision Committee, [1977] AJHR I.5.

${ }^{241} 415$ NZPD 4550, 17 November 1977.

242 415 NZPD 4159, 3 November 1977.
} 
already taken as progressive, yet flawed. It wanted a progressive approach to fix the issue, the National Party a regressive approach.

Just as accusations of self-interest had formed the majority of the argument against the 1975 Electoral Amendment Act, they played the same role in 1977. Labour members claimed the bill would "place opponents of the National Party at a disadvantage", ${ }^{243}$ that the government was using "steamroller tactics to improve the climate for its re-election", ${ }^{244}$ and that the bill "reek[ed] of political vindictiveness., 245 In opposition to the bill, Labour's David Lange criticised the impact of self-interest on electoral legislation. He said "it is our duty as Parliamentarians not to give the impression to the country that we as a Parliament are making the rules for our gain, irrespective of what party we are in. If ever a matter should be the subject of overall community participation, it should be the rules by which we are elected." 246

The arguments made against the bill by Labour Members and the arguments made for the bill by government Members were virtually an inversion of the arguments made by each side in 1975 . The parties had swapped sides in the House and seemingly swapped positions on the reform of the electoral law. From National's perspective, the government was able to divert from reaching total bipartisan consensus on the bill, as it was simply setting back to pre-1975 conditions the result of Labour's gerrymander in 1975 . In this, it restored the state of play to the way it had existed during the pre-1975 'era of consensus'. Two interesting arguments were made by National Members. Mr Latter, the Member for Marlborough, pointed out that, as

\footnotetext{
${ }^{243} 415$ NZPD 4161-62, 3 November 1977.

244415 NZPD 4161, 3 November 1977.

245415 NZPD 4562, 17 November 1977.

${ }^{246} 415$ NZPD 4556, 17 November 1977.
} 
National was mostly just repealing changes made in 1975, Labour Members could not argue the Bill was intended to advantage the government without implicitly implying that the 1975 legislation was intended to disadvantage the National Party. ${ }^{247}$ Brian Talboys, on the other hand, dismissed entirely the proposition that changes to the electoral law made by any government intending to advantage itself ever substantially altered the will of the electorate anyway: ${ }^{248}$

\begin{abstract}
Right - let us go back to 1972, when we went into an election under most of the provisions that the Government is now proposing. Who won the election? The Labour Party won ... so what is the use of that argument?... The next election was held under the conditions that the Labour Party insists should be in the Act. Who won that election? In 1975 the National Party won, and now the National Government wants to change the act.
\end{abstract}

After an acrimonious debate that went into the early hours of the morning, punctuated by frequent points of order and Speaker's rulings, the Bill was read a third time, with the House divided along party lines.

1977, however, did not mark the end of an argument that has continued into more recent times. In 1985, the Lange Labour Government reverted the three month residential requirement to one month. On this occasion, the government argued the change was a necessary technical measure as the result of the merging of the General and Local Body electoral rolls. David Caygill told the House that, with a residential qualifying period of one month, "the Post Office will find it easier to keep track of electors." 249 The Bill was introduced, read a first time, and referred to the Electoral Law Committee on a division along party lines. The committee considered the issues contained in the Bill during six meetings and eight hours of discussion. ${ }^{250}$ The debate

${ }^{247} 415$ NZPD 4561, 17 November 1977.
${ }^{248} 415$ NZPD 4564, 17 November 1977.
${ }^{249} 466$ NZPD 7042, 25 September 1985.
${ }^{250} 467$ NZPD 8145, 19 November 1985. 
on the Committee's report to the House was as acrimonious as it had been in 1975 . Again, the main accusation was self-interest. The bill was called a blatant attempt to help the Labour Party perpetrate electoral fraud, ${ }^{251}$ and that it would give Labour the opportunity to stack electorates in its favour. ${ }^{252}$ Parliament split along party lines for the ensuing readings and the Bill was passed by a division on the third reading. A matter relating to residence requirements arose again in 1989 when the Labour Government introduced legislation that overturned the decision in the famous Wairarapa electoral petition. ${ }^{253}$ Controversially, the Electoral Amendment Act 1989 was divided from the Local Government Reform Bill 1989 during its committee stages, when the two acts had nothing to do with one another. National opposed the measure, claiming it would open wide the determination of where an individual voter may exercise his or her vote in a general election and allow parties to gerrymander election results. ${ }^{254}$ The Bill was passed after an acrimonious debate about process and split along party lines. The final alteration of the enrolment requirements by the Fourth Labour Government occurred when legislation was passed allowing qualified electors to enrol up to the day before the election.

While the National Party members of the select committee did not actively oppose the change, which was only one of a number of changes in the legislation, in 1993 the Bolger Government again reversed the change through the Electoral Amendment Act 1993. That Act closed the electoral rolls for enrolment on Writ day, which was usually four weeks prior to a General Election. As National's Doug Graham pointed out in the Bill's introduction, in eleven out of the twelve elections between 1956 and

\footnotetext{
${ }^{251} 466$ NZPD 7043, 25 September 1985.

252466 NZPD 7044, 25 September 1985.

${ }^{253}$ National candidate, Wyatt Creech, successfully challenged the victory of Labour candidate, Reg Boorman, on the grounds Boorman had overspent in light of new spending limits.

${ }^{254} 498$ NZPD 10850, 23 May 1989.
} 
1990, the rolls had been closed on Writ Day. ${ }^{255}$ This was an issue that had divided National and Labour for many years. Self-interest was the main theme of the debate. Labour's Pete Hodgson called the legislation "a day of shame" and pledged to oppose it "down to the wire". ${ }^{256}$ It was claimed the government was shifting the goalposts by disenfranchising 20,000 people. Graham's argument that the date had been recommended in the report of the Electoral Law Committee on the 1990 General Election should be viewed in the knowledge that National held a majority on that committee. The Electoral Amendment Act 1993 displays again the differences in approach between the major parties: the National Party focussed on an elector's statutory duty to enrol within one month after becoming qualified to do so, and a Labour Party focussed on the government's role to assist electors in doing so. The opinion of National member Tony Ryall was typical of that expressed by many National MPs: "It is a small gesture to the democratic system to require people to enrol themselves at an appropriate time before an election." 257 The last time issues of enrolment were raised in Parliament was in 1995, when Jonathan Hunt introduced a Private Member's bill to move the latest day on which electors could register to vote back from Writ Day to the day before polling day. National Members defeated the bill on introduction. While 1975 to 1995 saw substantial disagreement on these issues, the Labour Government led by Helen Clark, elected in 1999, did not attempt to alter the law during its administration. The 'one month' requirement seemingly has emerged as a settled compromise between National and Labour.

\footnotetext{
255533 NZPD 13767, 9 March 1993.

${ }^{256} 533$ NZPD 13770, 9 March 1993.

${ }^{257} 546$ NZPD 5980, 8 March 1995.
} 
The areas discussed in chapters four and five all saw both disagreement and consensus between 1927 and 2007. The length of the parliamentary term, the number of Members of Parliament in the House, the qualifications to be a Member of Parliament, the formation of government, electorate boundaries and the franchise, all go straight to the heart of electoral law in New Zealand. Parliament has devoted no less time, however, to two other substantial areas of the electoral law. Chapter six now examines the administration of elections and the rules surrounding campaigning. 


\section{Chapter Six Election Administration and Electioneering}

The rules surrounding the administration of elections and the conduct of election campaigns can have a direct effect on the election success (or otherwise) of parties at election time. It is no surprise, then, that many of these rules caused a significant amount of controversy between 1927 and 2007.

\section{Election Administration}

Numerous issues relating to the administration of elections were altered by Parliament over the last eighty years. The majority of these changes were uncontroversial. The Electoral Amendment Act 1948, for example, clarified a number of ambiguities in the law that had arisen over several elections. The Electoral Amendment Act 1954 amended the Electoral Act in order to remove an ambiguity in the section of the Electoral Act 1927 that dealt with by-elections and the vacancy of seats. In 1972, the National Government introduced an electoral amendment bill to prevent a candidate from being nominated under a new name assumed under a deed poll less than six months before nominations closed. Returning officers had some discretion to waive the new rule. ${ }^{258}$ The bill was introduced in response to several incidents: in one, a man attempted to change his name to the name of a Walt Disney character in order to stand for Parliament; in another, a person changed his name to Jesus Christ; and, in another, a person who attempted to change his name to the exact name of another candidate for Wellington Central in order to stand against him. ${ }^{259}$ When these sorts of bills have arisen, and have presented no obvious advantage to

\footnotetext{
258381 NZPD 3487, 19 October 1972.

259381 NZPD 3487, 19 October 1972.
} 
either side, both major parties have engaged constructively in order to produce a workable piece of legislation.

Some of these bills nonetheless generated substantial debate. The Electoral Amendment Act 1971, for example, made minor technical changes to the Electoral Act. It did not amend any entrenched provisions and was the product of a review by the Public Expenditure Committee of the Electoral Act 1956. It was still, however, debated at length. Amendments to the process by which the electoral rolls are produced, for example, often caused some debate. In 1960, the Labour Government introduced legislation to amend the Electoral Act 1956 and facilitate the preparation of electoral rolls by a photographic process. In the committee stages, National members raised queries about whether the scheme would lead to inaccuracy, cause confusion, or whether it was even necessary. ${ }^{260}$ These objections were, for unknown reasons, absent by the bill's second reading a month later. John Marshall stated "the Opposition will be very pleased to facilitate the passing of this Bill, which is a technical one to enable the more efficient production of electoral rolls". ${ }^{261}$ Whatever objections had been made during the first reading, consensus had been reached in the interim - possibly due to the Opposition being briefed by the Minister or Ministry of Justice. The Bill passed its second and third readings without a division. ${ }^{262}$

In the aftermath of the Electoral Amendment Act 1975, the late 1970s saw the electoral rolls descend into an almost chaotic state due to problems in the administration of the rolls. Despite the attempts of the National Government to tidy up the rolls, as the 1978 election approached it became clear that the rolls would not

\footnotetext{
260322 NZPD 572, 14 July 1960.

261322 NZPD 1299, 14 July 1960.

262322 NZPD 1300, 14 July 1960.
} 
be fixed in time. In 1978 no fewer than four private members' bills seeking to fix the situation were debated in the House. The Electoral Amendment Bill (No 2) 1978, for example, was a private member's bill introduced by Michael Connelly, the Labour Member for Wigram. In the face of mounting problems with the preparation of the electoral rolls for the upcoming election, the bill sought to alter the Electoral Act in an attempt to ensure the enrolment of as many electors as possible prior to Election Day. The government argued that the bill was poorly drafted, ${ }^{263}$ and that the reason there had been problems assembling the rolls for the 1978 election was that Labour's 1975 Electoral Amendment Act had caused chaos. ${ }^{264}$ Labour Members argued that the government was opposing the bill on self-interested grounds and seeking political advantage by disqualifying from voting people who did not enrol by a set deadline. ${ }^{265}$ National Member Bill Birch summed up well the divide between the National and Labour parties on the issue of electoral enrolment: ${ }^{266}$

The difference between the two parties is that National members consider that the individual has a responsibility to register, and by registering he becomes eligible, whereas Labour members say they will not worry about the individual's eligibility until after the election, and that everybody should be entitled to go along and vote.

The bill was struck off the order paper after its second reading. Undeterred, however, Gerry Wall, Labour Member for Porirua, attempted to introduce another three bills before the election. The first, the Electoral Amendment Bill 1978, was an attempt to embarrass the government over the state of the electoral rolls. It proposed leaving enrolment open up until and during a general election and the introduction of an immunity clause to "protect people from... prosecution following their failure... to fulfil their [electoral] obligations under existing legislation.” The Bill was defeated on

\footnotetext{
${ }^{263} 418$ NZPD 1654, 11 July 1978.

${ }^{264} 418$ NZPD 1654, 11 July 1978.

265419 NZPD 1955, 19 July 1978.

${ }^{266} 418$ NZPD 1657, 11 July 1978.
} 
introduction. The Voting Rights Protection Bill 1978 was Wall's second attempt at forcing a re-organisation of the rolls just prior to the election. This Bill proposed alteration of the Electoral Act 1956 to provide franchise on eligibility to vote rather than being listed on the electoral roll. The Bill was voted down along party lines. Several months later, and just before the 1978 General Election, Wall introduced another bill relating to the preparation of the rolls. The bill sought to alter the Electoral Act 1956 so that "there should be no cessation of enrolment after the issue of the writs, and that people may legally enrol at the time they cast their votes."267 The bill was, in essence, another attempt to introduce the failed Voting Rights Protection Bill. The debate over the bill was especially acrimonious - the Opposition was concerned about the state of the electoral rolls and the impact of the situation on the Labour Party's prospects at the election, and the government was concerned about the state of the electoral rolls and the embarrassment it had been caused. Alongside this, the Wall Bill was the fourth electoral amendment bill introduced by an Opposition member that year. Accusations of self-interest were thrown at each side by the other. National's Minister of Justice, David Thomson, called the bill a "lastminute panic measure", ${ }^{268}$ and accused Labour of "messing about with the electoral law". ${ }^{269}$ Labour called Thomson "either grossly incompetent or corrupt", ${ }^{270}$ and alleged National had "found a situation it can exploit to advantage, not the promotion of democratic procedures or of democracy." 271

\footnotetext{
267420 NZPD 3423, 13 September 1978.

268420 NZPD 3424, 13 September 1978.

${ }^{269} 420$ NZPD 3424, 13 September 1978.

${ }^{270} 420$ NZPD 3433, 13 September 1978.

${ }^{271} 421$ NZPD 3745, 26 September 1978.
} 
While it was generally accepted that the rolls were not in a good state, Bruce Beetham summed up the difference in ideology that lay behind the approaches of the two parties: ${ }^{272}$

It is well known that complicated and diverse voting procedures tend to penalise the aged, the lesser educated, and even busy people, who cannot cope with the growing complexities of voting procedures. The complexity of the present system favours the National Party, which tends to be supported by people who have the time to wend their way through present complicated procedures, allowing their votes to qualify.

The problems encountered at the 1978 General Election forced the government to begin a substantial review of electoral administration law. As part of this process, Parliament established a committee chaired by James Wicks to inquire into the administration of the Electoral Act. ${ }^{273}$ The resulting Electoral Amendment Act 1979, passed just under a year after the 1978 General Election, attempted to provide a temporary fix to the dire situation that had occurred with the electoral rolls at the 1978 general election. The temporary solution was required due to the upcoming byelection caused by the death of Bruce Barclay, the member for Christchurch Central. The Bill proposed the use of a single roll in that contest. ${ }^{274}$ Minister of Justice Jim McLay said in the House that the bill, while rushed, fitted into the government's programme for a fundamental review of the Electoral Act. ${ }^{275}$ The 1979 Act provided a temporary solution until the Wicks Committee had recommended more substantive changes. ${ }^{276}$ McLay said in the bill's first reading that he had "discussed the need for the Bill and the procedures to be followed in respect of it" with his opposition counterpart, Richard Prebble, and the opposition had indicated it would co-operate in

\footnotetext{
272421 NZPD 3742, 26 September 1978.

${ }^{273} 424$ NZPD 1886, 31 July 1979.

${ }^{274} 424$ NZPD 1886, 31 July 1979.

275424 NZPD 1886, 31 July 1979.

${ }^{276} 424$ NZPD 1887, 31 July 1979.
} 
the bill's passing. ${ }^{277}$ Prebble, however, had a different interpretation, saying that the Opposition had pledged only "not to oppose" the bill because "no alternative course is open to Parliament." ${ }^{278}$ While the Bill had been proposed as a temporary measure, the Opposition argued strongly that the bill should go to a select committee. McLay agreed to its referral, based on assurance from Labour that the bill would be passed before the Christchurch Central by-election. ${ }^{279}$ Labour Party members raised objections to this proposal. Ultimately, Labour overplayed its hand. National MP Paul East accused the Opposition of breaching an agreement in order to grandstand. ${ }^{280}$ Nonetheless, most opposition was political rather than substantive. The bill was introduced and read a first time, and referred to the Statutes Revision Committee. ${ }^{281}$ The Committee reported the bill back and recommended it be allowed to proceed without amendment. ${ }^{282}$ Several technical amendments were made during the Committee stages and the bill passed without a division.

The Electoral Amendment Act 1980 was the first of several successive acts that arose out of the reports of the Wicks Committee and the Electoral Law Select Committee. After 1975, it was the second example of the introduction of a bill that was the result of select committee proceedings, rather than being drafted before being considered by a select committee. The Act aimed to fix the process that had caused such chaos with the electoral rolls at the 1978 General Election. On this subject, which formed the majority of the bill, government and opposition were united. They were further united on the three administrative clauses of the Act that affected entrenched provisions. The 1980 Bill, however, also introduced several controversial amendments that did not




enjoy unanimous support. These included delaying the date of the Maori option by a year and removing the name of each candidate's party from the ballot paper, a move discussed later in this chapter.

In terms of the precise changes made, the Act made some quite significant changes to the organisation of electoral rolls. It made the Post Office solely responsible for the compilation of the electoral rolls, and removed the role of the Ministry of Justice, ${ }^{283}$ and the system of census re-registration introduced in 1975 was abolished and replaced with 3-yearly roll revisions. ${ }^{284}$ It introduced a network of computer terminals to compile the rolls, ${ }^{285}$ and set down in statute the "long-standing administrative practice" to allow electors' names not to be published on the electoral roll. ${ }^{286}$ While Labour agreed with "90 percent" of the bill, "10 percent [was] disgraceful."287 Indeed, the acrimony over the non-unanimous changes led to the debate on the 1980 bill becoming the longest debate on Electoral Law legislation in New Zealand to date. The second reading debate alone took seven hours. ${ }^{288}$ The bill also provides the first example of a National Government forcing through the House changes to the electoral law for which there was not unanimous support, and which were not just amendments repealing amendments made by another government (such as National's 1977 introduction of the bill repealing parts of the Electoral Amendment Act 1975). The opposition opposed the introduction of the Bill in order to make the point that it disagreed with a number of the provisions. ${ }^{289}$ The bill was introduced and referred

\footnotetext{
283433 NZPD 3164, 3 September 1980.

${ }^{284} 433$ NZPD 3164, 3 September 1980.

285433 NZPD 3165, 3 September 1980.

286433 NZPD 3166, 3 September 1980.

287433 NZPD 3523, 18 September 1980.

288433 NZPD 3872, 1 October 1980.

${ }^{289} 433$ NZPD 3167, 3 September 1980.
} 
again to the Electoral Law Committee along party lines. ${ }^{290}$ The select committee made progress on the administrative matters concerning the electoral rolls but tripped up on matters of disagreement. Prebble complained of the "arrogant power" on show and accused the government of behaving in a partisan manner. ${ }^{291}$ On the presentation of the committee's report to the House, Labour moved unsuccessfully to send the bill back to the Electoral Law Committee. ${ }^{292}$ The majority of decisions of the select committee was unanimous. ${ }^{293}$ This is a common thread running through the history of amending the electoral law; often several provisions in a bill derailed, or threatened to derail, the entire process, including those provisions on which there existed agreement. The debate was complicated by the 75 percent support requirement for minor changes to three entrenched provisions of the Electoral Act. While these were tacitly supported by all sides in the select committee process, the opposition used the influence conferred on it by the entrenched provisions to threaten the government. It was not until the last minute that Labour informed McLay that it would support the entrenched changes. McLay complained that officials had to spend two working days drafting alternative proposals to deal with the problems that might have arisen if the changes to those entrenched provisions had not been agreed to by a 75 percent majority. ${ }^{294}$ As usual, accusations of self-interest were made. Labour accused National of self-interested behaviour for delaying the Maori option and removing the names of candidates' parties from the ballot paper. National accused Labour of selfinterest for opposing both moves. ${ }^{295}$ Ultimately, the House divided along party lines to read the bill a second time. The bill passed with no division being taken on the

\footnotetext{
${ }^{290} 433$ NZPD 3184, 3 September 1980.

${ }^{291} 433$ NZPD 3528, 18 September 1980.

292433 NZPD 3522, 18 September 1980.

293433 NZPD 3169, 3 September 1980.

${ }^{294} 434$ NZPD 3916, 3 October 1980.

${ }^{295} 433$ NZPD 3798, 30 September 1980.
} 
third reading. The Opposition opposed the clauses it disagreed with individually in the committee stages.

The next bill to arise from the recommendations of the Wicks' Committee was the Electoral Amendment Bill 1983. The bill implemented the recommendations contained in the third report of the Electoral Law Committee. ${ }^{296}$ It raised little debate and was read a third time with no debate or division. ${ }^{297}$ The final Act passed in the post-1978 review was the Electoral Amendment Act 1985. It was primarily technical and all the substantive measures in the Bill were the result of the unanimous recommendations of the Electoral Law Committee. ${ }^{298}$ The Bill had broad support and received only one speech from the Minister and from the Opposition for its second reading. It was reported without amendment or debate in its committee stages and read a third time with no debate. Jonathan Hunt pointed out that the Electoral Law Committee had come to play "an essential part in the way electoral legislation is dealt with in the House." 299

Despite the introduction of MMP, amendments to the area of electoral administration seldom arose after 1985 . The work done in the early 1980s was not superseded by the change in electoral system. Some matters of controversy did arise at times. For example, there was a point of contention between National and Labour in the debate over the Electoral Amendment Act (No 2) 1995. The act introduced the crossmatching of immigration data to the electoral rolls. Labour Members, such as David Caygill, claimed this would create a disincentive to enrolment. ${ }^{300}$ Interestingly, one of

\footnotetext{
${ }^{296} 454$ NZPD 3462, 27 October 1983.

${ }^{297} 455$ NZPD 4837, 13 December 1983.

298464 NZPD 5929, 25 July 1985.

${ }^{299} 468$ NZPD 8632, 3 December 1985.

${ }^{300} 547$ NZPD 6662, 4 April 1995.
} 
the first times the new MMP electoral system influenced the passage of an electoral law amendment was on a bill dealing with administration. The Electoral Amendment Bill 1998 provides a rare example of a government Electoral Bill failing - this Bill lapsed, along with a number of others, when the National-New Zealand First Government fell apart. The Bill was relatively non-controversial and sought to implement the changes recommended by the Electoral Law Committee in its report on the 1996 General Election. The Bill had opposition support and, in 2002, the Labour Government resurrected the bill from the bottom of the Order Paper and incorporated it into the Electoral Amendment Act 2002.

Perhaps the most contentious electoral administration issue during the entire period from 1927 to 2007 concerned the method of voting and design of the ballot paper. Parliament often acted unanimously in making changes to assist those who might otherwise have trouble voting. For example, changes to aid the disabled and elderly to vote usually received bi-partisan support. The earliest example of this was in the Coalition Government's otherwise controversial 1934 Electoral Amendment Act which made provision for a change of system in the recording of a blind person's vote at a parliamentary election. ${ }^{301}$ The area where disagreement has most often occurred concerned the design of the ballot paper and the method of marking it. As mentioned above, one of the more controversial changes in this regard was made by the Muldoon Government in 1980 when it removed party designations from the ballot paper. This seemingly pointless move caused great dissent from the Opposition, which called the move "shameful" and "raw political power at its worst". ${ }^{302}$ In 1990 the Palmer Labour Government returned the names of candidates' parties to the

\footnotetext{
301240 NZPD 350, 4 October 1934.

302433 NZPD 3172, 3 September 1980.
} 
voting paper, reversing this change. National did not oppose the move. ${ }^{303}$ The method of voting was also changed from crossing out the names of candidates to ticking the box of the candidate. This change received the unanimous support of the House.

In the aftermath of the 1993 referendum on the electoral system, decisions had to be made on the layout of the new voting paper now that two votes were to be exercised on a single paper. In 1995, and just before the first MMP election, Labour and National banded together to amend an entrenched provision that concerned the layout of the ballot paper. The provision randomised the order of party names on the ballot paper and, most controversially, aligned the electorate candidate for each party with the party vote column. Understandably, the small parties accused National and Labour of self-interest in changing the rule, although it should be remembered that their accusations were made out of a move to protect their own interests. Self-interest was at work on all sides. United's Clive Matthewson accused "the two old parties" of "overrul[ing] the rights of the minority in this House." ${ }^{304}$ New Zealand First and the Alliance attempted to send the bill back to select committee to reconsider the ballot paper issue, but this move was defeated by National and Labour. Labour and National voted together on all divisions; the minor parties obstructed with numerous amendments and divisions. Ultimately, however, the provisions passed. The design of the ballot paper was not altered after 1995, which was also the last year Labour and National banded together to override the objections of minor parties.

\footnotetext{
${ }^{303} 502$ NZPD 13365, 7 November 1989.

${ }^{304} 551$ NZPD 10064, 22 November 1995.
} 
This chapter has so far examined the administration of elections and the electoral rolls. It now turns to the responsibilities placed by legislation on those standing for Parliament.

\section{Electioneering}

Election expenses were not frequently debated until after the Second World War. The Electoral Amendment Act 1948 raised the limit on candidates' campaign spending for the first time since 1895 - from $£ 200$ to $£ 500 .{ }^{305}$ Throughout the post-war period, the limit on candidates' election expenditure gradually increased: to $\$ 2000$ in 1975 , to $\$ 4000$ in 1977 , and to $\$ 10,000$ in 1990 . Disagreement occurred on a number of occasions, not just over spending limits, but how election campaigns are financed. In 1960, for example, the Labour Government's Political Disabilities Removal Act restored the ability of unions to make levies for political purposes. It had been repealed under the former National Government in 1950. The National Party strongly opposed the bill, which had the direct effect of securing funds for the Labour Party. National accused self-interest and Labour Members did not deny it. The Bill, however, skirted the edges of what constituted 'electoral law', as such. Thus no objection was raised by the National Opposition that the bill breached any moral duty to seek consensus on the electoral law. In 1960, the topic of campaign funding was not yet considered an electoral matter.

Parliament often devoted its attention to matters perhaps not worthy of extensive consideration. An example of this is the attention it paid to the use of loudspeakers in election campaigns. The argument stemmed from Labour Member Rex Mason's 1965 Electoral Amendment Bill 1965 which sought, in the face of increasing use of

${ }^{305}$ Atkinson, Adventures in Democracy, p. 160. 
television and other media for electioneering, to promote the 'corner meeting' style of campaigning by allowing meetings to be held "without reference to bylaws." ${ }^{306}$ It seems that Mason was under no apprehension that the bill would be successful. His main object was to see his provisions, or provisions along their lines, inserted into the government's own Electoral Amendment Bill, already in front of the House at that stage. $^{307}$ The government adopted a consensual approach to the bill; Hanan said the Bill would "receive the most careful and earnest consideration of the Government", 308 and that the government would "adopt any constructive and useful suggestions coming from the opposition." ${ }^{309}$ The second reading debate was relatively long and one which focussed around the intricacies of the use of loudspeakers, the possibility of traffic being held up by political street meetings, the bill's effect on by-laws and the privacy of people in their houses - hardly a fundamental piece of electoral law reform in New Zealand's history. Nonetheless the debate descended into an acrimonious two hours of accusations over campaign practices and members' personal integrity. This most insignificant of bills produced a partisan debate in line with the acrimony present in the debates on the government's own Electoral Amendment Bill 1965. Aside from questions over the quality of the bill's drafting and its legal complications, the government's main objection during the second reading was whether the bill was necessary. It would further override a number of bylaws and local government regulations. ${ }^{310}$ The Bill was defeated along party lines, becoming the first unsuccessful electoral bill introduced since the 1930s. The matter came up for debate a decade later, when the Rowling Government included a clause in the Electoral Amendment Act 1975 overriding the control of local bodies in the

\footnotetext{
306342 NZPD 173, 4 June 1965.

307342 NZPD 173, 4 June 1965.

308342 NZPD 173, 4 June 1965.

309342 NZPD 174, 4 June 1965.

310342 NZPD 932, 1 July 1965.
} 
matter of electioneering with loudspeakers. National objected for the same reasons it had objected to Mason's bill in 1965. The National Party promised to repeal the law and did so in $1977 .^{311}$

The process through which the regulation of campaigns increased after the 1970s was a gradual one. The Electoral Amendment Act 1977, for example, introduced a new provision regulating candidate advertisements, requiring them to be authorised in writing by the candidate and containing the address of a person responsible for the advertisement. This was by far the most extensive provision in this area legislated for by the New Zealand Parliament up to that point. ${ }^{312}$ Several private members' bills sought to regulate government advertising in an election year. The Political Advertising Bill 1986, for example, proposed extensive limits on expenditure by government on advertising and restrictions on the types of advertising for which public money could be used. It was defeated on introduction. In 1988, National MP Simon Upton introduced the Public Finance (Restraint of Political Advertising) Bill, which sought to force the government to itemise all money spent on advertising government policies. The Bill stated that advertising would be defined as political if its predominant purpose was the promotion of any Minister of the Crown, Member of Parliament, parliamentary candidate, or political party, or if it sought to persuade the public of the merits of government policy. The government characterised the bill as "ludicrous and senseless" and the House voted along party lines not to introduce the bill. In 1995, the Disclosure of Political Donations and Gifts Bill, introduced by the New Zealand First leader, Winston Peters, sought to create a register of all substantial donations made to political parties or candidates. Labour, the Alliance, United New

\footnotetext{
311398 NZPD 2093, 12 June 1975.

312416 NZPD 5145, 7 December 1977.
} 
Zealand and the Right of Centre Party all indicated support for its introduction. The National-led Government questioned its necessity, as the issue of donations was already before the Electoral Law Committee. ${ }^{313}$ The Electoral Law Committee, which considered the bill, recommended it not proceed on this basis. Labour agreed with this step, as the Electoral Reform Bill 1995 had proposed a disclosure regime in the interim.

The provisions in the Electoral Reform Bill had emerged from concerns of the Electoral Law Committee about the appearance of anonymous election advertising in the 1993 election. Doug Graham argued that "such advertising undermines the democratic process because voters cannot assess the bona fides of persons promoting anonymous election advertisements. ${ }^{\prime 314}$ The Act made it an offence to publish or broadcast any electoral advertisement unless the true name and address of the person for whom or at whose direction it was published was contained in the advertisement. Importantly, the Act required, for the first time, that parties disclose publicly all substantial donations. This was the first time a limit had been set on total party expenditure. The parties were substantially agreed on campaign spending limits, and the select committee exhaustively debated the issue. As its chair, Tony Ryall, said on the report of the select committee to the House: $:^{315}$

Every one of the five parties represented on the select committee has had to give ground. Every party has had to compromise. Different combinations supported and opposed various clauses. But this Bill shows that we can achieve substantial reform through sensible, compromising consensus in the select committee environment.

\footnotetext{
313550 NZPOD 9061, 20 September 1995

314547 NZPD 6662, 4 April 1995.

315551 NZPD 9942, 19 October 1995.
} 
The move to regulate campaign spending and electioneering was taken to its extreme in the Electoral Finance Act 2007. The Act introduced further restrictions on campaigning, electioneering, funding and other activities. It instituted a financial agent system with heavy penalties, required the public to register as "third parties" in order to participate in a General Election, and significantly reduced allowable election expenditure. The Act caused significant controversy in Parliament and the media, and protest throughout New Zealand. Ultimately, the Act (which conferred large advantages on an incumbent government) may have actually harmed the government that introduced it. In 2009, the Labour Party, now in Opposition, admitted that the bill had been a mistake. ${ }^{316}$

The issue of opinion polling was considered by Parliament on a number of occasions. The Electoral Amendment Act 1981 banned exit polling, a move which had the support of all parties. ${ }^{317}$ In 2000, the Electoral (Public Opinion Polls) Amendment Bill, introduced by Winston Peters, proposed a 28-day period prior to a general election or a by-election during which it would be an offence to publish the results of a public opinion poll conducted during that period in relation to the general election or a by-election. National and Labour both supported the bill to select committee so it could be considered there. The bill failed on its First Reading. Interestingly, the National Party, which has traditionally been more averse to restrictions on campaigning than the Labour Party, supported Peters' bill. The reasons behind this are not clear. Another attempt to regulate opinion polling came in the Clark Government's Electoral Amendment Act 2002. The bill, as introduced, banned the publishing of opinion polls before an election. This was despite the government's

\footnotetext{
${ }^{316}$ See comments of Phil Goff, above $\mathrm{n} 4$.

317442 NZPD 4177, 15 October 1981.
} 
opposition to Winston Peters' bill in 2000. Due to overwhelming pressure, however, the offending clause was removed in the committee stages. Green MP Rod Donald suggested the government had been pressured into inserting the opinion polls provision by Winston Peters threatening not to support other government legislation. ${ }^{318}$ There were foreshadows of the draconian nature of the Electoral Finance Act 2007 in this bill. The bill as reported back from select committee contained a provision that said journalists would be guilty of a corrupt practice if they at any time published or distributed any material or information that may be false. National accused the government of "breaking the bipartisan approach that we have had to electoral law in this country for many, many years." ${ }^{319}$ In truth, that approach had been followed somewhat haphazardly since 1975 .

\section{Broadcasting}

Broadcasting formed an essential part of election campaigning throughout the period studied. While radio broadcasting has formed a part of New Zealand election campaigns since the 1930s, state intervention in television and radio advertising only began in the late 1980s. The 1989 Broadcasting Act included a provision that empowered the Parliamentary Service Commission to allocate six hours of appropriated TV and radio advertising among parties. The clause resulted from a recommendation in the report of the Royal Commission on the Electoral System. The Bill was referred to the Planning and Development Committee for consideration. The committee made several important changes to improve the Act's workability, and altered a clause to allow the Opposition to appoint a member to the Broadcasting Standards Authority when it sat to allocate free advertising time to parties and when it

\footnotetext{
318590 NZPD 8279, 15 March 2001.

${ }^{319} 598$ NZPD 14613, 26 February 2002.
} 
met to consider complaints. National objected to the situation of Parliament demanding free airtime from broadcasters, ${ }^{320}$ and moved in the committee stages to have the Parliamentary Service pay for political advertising, instead of the broadcasters themselves: this was voted down along party lines. Although National disagreed with the clauses concerning election broadcasting, these formed but a minor part of the bill, which was read a third time without division. Further major change came the following year with the Broadcasting Amendment Act 1990. At a very late stage in the committee process, the government introduced amendments to the Broadcasting Act passed the previous year. While it introduced a number of minor changes recommended by the Broadcasting Standards Authority, it also vastly expanded the amount of free-to-air advertising on television and radio stations in an election year.

The Opposition claimed that Labour was indulging in self-interested politics and that the bill was the action of a divided political party which could not afford to pay for election advertising and was thus appropriating free time for itself. At the same time, National benefitted from the free advertising. National MP Jim Gerard claimed "the Opposition could not vote against the measure while knowing that it would have to take the benefit---that would have been totally immoral". ${ }^{321}$ Despite the controversy, the Bill was read a third time without a division. The haste with which changes had been made under the Broadcasting Amendment Act 1990 necessitated the Broadcasting and Radiocommunications Reform Act 1990, which was introduced by the Palmer Government to correct a number of deficiencies in the earlier legislation.

320497 NZPD 10413, 4 May 1989.

321505 NZPD 452-53, 7 March 1990. 
The government acknowledged that the legislation had not worked as intended, ${ }^{322}$ and that the new legislation was the result of consulting with broadcasters before passing it. As Hunt outlined, the government had "moved away from any imposition of obligations on broadcasters... There is no compulsion." ${ }^{323}$ Secondly, in line with the recommendations of the Royal Commission on the Electoral System, a small amount of publicly-funded election broadcasting was introduced. National opposed the legislation on the basis that it introduced political funding of election advertising just before an election. Gerard called it a "threat to democracy on the eve of an election campaign". ${ }^{324}$ Labour was further funding its election campaign by use of legislation. The bill was read a first time and referred to the Planning and Development Committee, which received submissions from most major media organisations. National opposed the bill through the committee stages and the bill was passed by a divided House on its third reading.

The introduction of MMP necessitated changes to the election broadcasting law. The Broadcasting Amendment Act 1996 aimed to adapt the election broadcasting regime to suit an MMP environment. ${ }^{325}$ Most importantly, it transferred administration of the electoral broadcasting regime from the Broadcasting Standards Authority to the newly established Electoral Commission. Labour supported the move, noting that the Electoral Law Committee had recommended it happen on several occasions and that bipartisan support had always existed. ${ }^{326}$ The minor parties objected to the provisions that allowed the government and opposition to each appoint a member to the Electoral Commission for the purposes of deciding electoral broadcasting. This was

\footnotetext{
322508 NZPD 2615, 28 June 1990.

323508 NZPD 2615, 28 June 1990.

${ }^{324} 508$ NZPD 2616, 28 June 1990.

${ }^{325} 551$ NZPD 9974, 19 October 1995.

${ }^{326} 551$ NZPD 9975, 19 October 1995.
} 
the second bill in two years on which the two major parties had united to make a change to the law that helped them in the face of opposition from minor parties. The bill also contained a provision that would have allowed parties to use their own money to buy further broadcasting. Labour vigorously opposed this move, and the government was forced to remove it during the select committee stage under threat of delaying tactics from the Labour Members. ${ }^{327}$ With this clause removed, Labour and National voted for the bill and United, New Zealand First, Alliance and the New Zealand Conservative Member voted against it. After the 1996 Act, the broadcasting regime in New Zealand remained unamended and relatively uncontroversial.

${ }^{327} 556$ NZPD 13374, 25 June 1996. 


\section{Chapter Seven}

\section{Assessing Trends and Motivations}

A number of themes and findings emerge from the analysis in chapters three to six, ranging from governments using the mandate as a justification for changing the electoral law, to the influence that entrenchment has had on the process by which reserved provisions were amended. The chapters covered acts of all levels of contention, types of outcome, and subject matter. There were examples of acts probably motivated by self-interest and others passed in a spirit of co-operation.

Using this information, chapter seven assesses the processes and motivations behind electoral law change. First, some obvious findings are presented. As shown in Table 8 , the higher the level of contention during a bill's passage through the House, the higher the likelihood that its outcome will not be unanimous.

Table 8 - Contention v Outcome of Electoral and Electoral Amendment acts passed under National or National-led and Labour or Labour-led Governments 1927-2007

\begin{tabular}{|c|c|c|c|c|c|c|c|c|c|c|c|}
\hline & \multirow{3}{*}{$\begin{array}{l}\mathbf{N}=\text { National } \\
\mathbf{L}=\text { Labour }\end{array}$} & \multicolumn{10}{|c|}{ Outcome } \\
\hline & & \multicolumn{2}{|c|}{ Unanimous } & \multicolumn{2}{|c|}{$\begin{array}{c}\text { Not } \\
\text { Opposed }\end{array}$} & \multicolumn{2}{|c|}{$\begin{array}{l}\text { No Multi- } \\
\text { partisan } \\
\text { Support }\end{array}$} & \multicolumn{2}{|c|}{ Opposed } & \multicolumn{2}{|c|}{ Totals } \\
\hline & & $\mathbf{N}$ & $\mathrm{L}$ & $\mathrm{N}$ & $\mathbf{L}$ & $\mathbf{N}$ & $\mathbf{L}$ & $\mathbf{N}$ & $\mathbf{L}$ & $\mathbf{N}$ & $\mathbf{L}$ \\
\hline \multirow{5}{*}{ } & High & - & - & 2 & - & - & - & 2 & 9 & 4 & 9 \\
\hline & Moderate & - & - & 5 & 3 & 1 & - & 2 & 1 & 8 & 4 \\
\hline & Low & 2 & 2 & 7 & 5 & 1 & - & - & - & 10 & 7 \\
\hline & None & 5 & 3 & 5 & 8 & - & - & - & - & 10 & 11 \\
\hline & Total & 7 & 5 & 19 & 16 & 2 & - & 4 & 10 & 32 & 31 \\
\hline
\end{tabular}


Out of thirteen acts that had high levels of contention, only two were unopposed in their third readings. Of the twelve acts with moderate levels of contention, only three were ultimately opposed by the main Opposition. One was opposed only by minor parties. Those bills with low and no contention all passed either unanimously or unopposed by the main opposition party. No major differences exist when the figures are considered by party-majority in a government. Similar amounts of low and noncontentious legislation was passed under National and National-led, and Labour and Labour-led governments. Labour and Labour-led governments saw the passage of more highly contentious legislation, although, when the high and moderate categories are combined, these figures are similar: twelve high or moderately contentious acts under National, and thirteen under Labour. Overall, no major differences emerge between the parties here.

Tables 9 and 10 examine, respectively, the levels of contention and the outcome for various subject areas of the electoral law. Table 9 shows that the areas of lowest contention were: election administration; by-elections; MP Qualification (although both parties passed highly contentious acts in this area); referenda; technical amendments; and term length. The areas of highest contention were boundaries, where significantly more legislation was passed under National and National-led governments than under Labour and Labour-led governments; broadcasting, where Labour and Labour-led governments passed significantly more legislation; electioneering and finance; the method of voting and franchise and registration, where virtually all legislation passed under Labour and Labour-led governments was highly contentious. 
Table 9 - Contention v Category of Electoral and Electoral Amendment acts passed under National or National-led and Labour or Labour-led Governments 1927-2007

\begin{tabular}{|c|c|c|c|c|c|c|c|c|c|c|c|c|c|c|c|c|c|c|c|c|c|c|c|c|c|c|c|c|c|c|}
\hline \multirow{3}{*}{\multicolumn{2}{|c|}{$\begin{aligned} \mathbf{N} & =\text { National Govt } \\
\mathbf{L} & =\text { Labour Govt }\end{aligned}$}} & \multicolumn{29}{|c|}{ Category } \\
\hline & & \multicolumn{2}{|c|}{ Admin. } & \multicolumn{2}{|c|}{ Bound. } & \multicolumn{2}{|c|}{ Broad. } & \multicolumn{2}{|c|}{$\begin{array}{c}\text { By- } \\
\text { Election }\end{array}$} & \multicolumn{2}{|c|}{ Constit. } & \multicolumn{2}{|c|}{$\begin{array}{c}\text { Election. } \\
\& \\
\text { Finance }\end{array}$} & \multicolumn{2}{|c|}{$\begin{array}{c}\text { Electoral } \\
\text { System }\end{array}$} & \multicolumn{2}{|c|}{$\begin{array}{c}\text { Franch. } \\
\text { \& Reg. }\end{array}$} & \multicolumn{2}{|c|}{ Maori } & \multicolumn{2}{|c|}{$\begin{array}{c}\text { Method } \\
\text { of } \\
\text { Voting }\end{array}$} & \multicolumn{2}{|c|}{$\begin{array}{c}\text { MP } \\
\text { Qual. }\end{array}$} & \multicolumn{2}{|c|}{$\begin{array}{c}\text { Number } \\
\text { of MPs }\end{array}$} & Ref. & \multicolumn{2}{|c|}{ Tech. } & \multicolumn{2}{|c|}{$\begin{array}{c}\text { Term } \\
\text { Length }\end{array}$} \\
\hline & & $\mathrm{N}$ & $\mathrm{L}$ & $\mathbf{N}$ & $\mathrm{L}$ & $\mathbf{N}$ & $\mathbf{L}$ & $\mathbf{N}$ & $\mathrm{L}$ & $\mathbf{N}$ & $\mathrm{L}$ & $\mathrm{N}$ & $\mathbf{L}$ & $\mathbf{N}$ & $\mathbf{L}$ & $\mathbf{N}$ & $\mathbf{L}$ & $\mathrm{N}$ & I & $\mathrm{N}$ & $\mathrm{L}$ & $\mathrm{N}$ & I & 1 & I & & $\mathbf{N}$ & $\mathrm{L}$ & $\mathbf{N}$ & $\mathrm{L}$ \\
\hline \multirow{5}{*}{ نُ } & High & 1 & 3 & 2 & 1 & - & 2 & - & - & 1 & - & 2 & 4 & 1 & - & 3 & 5 & 1 & 2 & 1 & 1 & 1 & 2 & 1 & - & & - & - & - & - \\
\hline & Moderate & 4 & 1 & 1 & - & - & 2 & - & 1 & - & - & 1 & 2 & - & - & 4 & - & 2 & 1 & 1 & 1 & - & 2 & - & - & & - & - & - & - \\
\hline & Low & 7 & 3 & 2 & - & 1 & 1 & 1 & - & 1 & - & 4 & - & - & - & 2 & - & 3 & 1 & 2 & - & 2 & 2 & - & - & & 2 & - & - & 2 \\
\hline & None & 2 & 2 & 2 & - & - & - & 1 & 1 & - & 1 & - & 1 & - & - & 1 & 2 & 2 & 2 & - & - & 2 & 3 & - & - & & 2 & 1 & - & 1 \\
\hline & Total & 14 & 9 & 7 & 1 & 1 & 5 & 2 & 2 & 2 & 1 & 7 & 7 & 1 & - & 10 & 7 & 8 & 6 & 4 & 2 & 5 & 9 & 1 & - & & 4 & 1 & - & 3 \\
\hline
\end{tabular}


Table 10 - Outcome v Category of Electoral and Electoral Amendment acts passed under National or National-led and Labour or Labour-led Governments 1927-2007

\begin{tabular}{|c|c|c|c|c|c|c|c|c|c|c|c|c|c|c|c|c|c|c|c|c|c|c|c|c|c|c|c|c|c|c|c|}
\hline \multirow{3}{*}{\multicolumn{2}{|c|}{$\begin{aligned} \mathbf{N} & =\text { National Govt } \\
\mathbf{L} & =\text { Labour Govt }\end{aligned}$}} & \multicolumn{30}{|c|}{ Category } \\
\hline & & \multicolumn{2}{|c|}{ Admin. } & \multicolumn{2}{|c|}{ Bound. } & \multicolumn{2}{|c|}{ Broad. } & \multicolumn{2}{|c|}{$\begin{array}{c}\text { By- } \\
\text { Election }\end{array}$} & \multicolumn{2}{|c|}{ Constit. } & \multicolumn{2}{|c|}{$\begin{array}{c}\text { Election. } \\
\& \\
\text { Finance }\end{array}$} & \multicolumn{2}{|c|}{$\begin{array}{l}\text { Electoral } \\
\text { System }\end{array}$} & \multicolumn{2}{|c|}{$\begin{array}{l}\text { Franch. } \\
\text { \& Reg. }\end{array}$} & \multicolumn{2}{|c|}{ Maori } & \multicolumn{2}{|c|}{$\begin{array}{c}\text { Method } \\
\text { of } \\
\text { Voting }\end{array}$} & \multicolumn{2}{|c|}{$\begin{array}{c}\text { MP } \\
\text { Qual. }\end{array}$} & \multicolumn{2}{|c|}{$\begin{array}{l}\text { Number } \\
\text { of MPs }\end{array}$} & \multicolumn{2}{|c|}{ Ref. } & \multicolumn{2}{|c|}{ Tech. } & \multicolumn{2}{|c|}{$\begin{array}{c}\text { Term } \\
\text { Length }\end{array}$} \\
\hline & & $\mathrm{N}$ & $\mathrm{L}$ & $\mathrm{N}$ & $\mathrm{L}$ & $\mathrm{N}$ & $\mathrm{L}$ & $\mathbf{N}$ & $\mathbf{L}$ & $\mathbf{N}$ & $\mathrm{L}$ & $\mathrm{N}$ & $\mathbf{L}$ & $\mathbf{N}$ & $\mathbf{L}$ & $\mathbf{N}$ & $\mathrm{L}$ & $\mathbf{N}$ & $\mathrm{L}$ & $\mathbf{N}$ & $\mathrm{L}$ & $\mathrm{N}$ & $\mathbf{L}$ & $\mathrm{N}$ & $\mathbf{L}$ & $\mathbf{N}$ & $\mathrm{L}$ & $\mathbf{N}$ & $\mathbf{L}$ & $\mathrm{N}$ & $\mathbf{L}$ \\
\hline \multirow{5}{*}{ 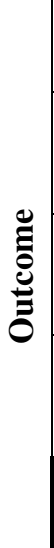 } & Opposed & - & 3 & 1 & 1 & - & 2 & - & - & - & - & 1 & 4 & - & - & 3 & 5 & 1 & 2 & - & 1 & - & 3 & - & - & - & - & - & - & - & - \\
\hline & $\begin{array}{l}\text { No Multi- } \\
\text { partisan } \\
\text { Support } \\
\end{array}$ & 1 & - & - & - & 1 & - & - & - & - & - & 2 & - & - & - & - & - & - & - & 1 & - & - & - & - & - & - & - & - & - & - & - \\
\hline & Not Opposed & 11 & 5 & 4 & - & - & 3 & 2 & 1 & 1 & 1 & 3 & 3 & 1 & - & 6 & 1 & 6 & 4 & 2 & 1 & 4 & 5 & 1 & - & 1 & 1 & 2 & 1 & - & 1 \\
\hline & Unanimous & 2 & 1 & 2 & - & - & - & - & 1 & 1 & - & 1 & - & - & - & 1 & 1 & 1 & - & 1 & - & 1 & 1 & - & - & 2 & - & 2 & - & - & 2 \\
\hline & Total & 14 & 9 & 7 & 1 & 1 & 5 & 2 & 2 & 2 & 1 & 7 & 7 & 1 & - & 10 & 7 & 8 & 6 & 4 & 2 & 5 & 9 & 1 & - & 3 & 1 & 4 & 1 & - & 3 \\
\hline
\end{tabular}


Table 10 shows that only a very few areas of the electoral law were mostly opposed by opposition parties in the House. Only broadcasting, and electioneering and finance, approach this status. In both cases, the areas are split evenly between opposed legislation and unopposed or unanimous legislation. So while boundaries, franchise and the method of voting were often contentious areas, this contention, in more cases than not, did not result in opposition on the final vote in the House.

Table 11 compares contention and class. The 'class' category, as outlined in chapter three, considers the importance of a bill in terms of the scope and effect of each Act in comparison to other electoral bills.

Table 11 - Contention v Class of Electoral and Electoral Amendment acts passed under National or National-led and Labour or Labour-led Governments 1927-2007

\begin{tabular}{|c|c|c|c|c|c|c|c|c|c|c|c|}
\hline \multirow{3}{*}{\multicolumn{2}{|c|}{$\begin{aligned} \mathbf{N} & =\text { National Govt } \\
\mathbf{L} & =\text { Labour Govt }\end{aligned}$}} & \multicolumn{10}{|c|}{ Contention } \\
\hline & & \multicolumn{2}{|c|}{ None } & \multicolumn{2}{|c|}{ Low } & \multicolumn{2}{|c|}{$\begin{array}{l}\text { Mode- } \\
\text { rate }\end{array}$} & \multicolumn{2}{|c|}{ High } & \multicolumn{2}{|c|}{ Totals } \\
\hline & & $\mathrm{N}$ & $\mathrm{L}$ & $\mathbf{N}$ & $\mathbf{L}$ & $\mathbf{N}$ & $\mathrm{L}$ & $\mathbf{N}$ & $\mathrm{L}$ & $\mathrm{N}$ & $\mathbf{L}$ \\
\hline \multirow{5}{*}{$\frac{\tilde{E}}{\tilde{E}}$} & Milestone & - & - & 1 & - & - & - & 1 & 1 & 2 & 1 \\
\hline & Major & - & 2 & 2 & 1 & 6 & 3 & 3 & 5 & 11 & 11 \\
\hline & Minor & 4 & 3 & 4 & 5 & 2 & 1 & - & 3 & 10 & 12 \\
\hline & Incidental & 6 & 6 & 3 & 1 & - & - & - & - & 9 & 7 \\
\hline & Total & 10 & 11 & 10 & 7 & 8 & 4 & 4 & 9 & 32 & 31 \\
\hline
\end{tabular}

The majority of electoral legislation in New Zealand garnered no or low contention. 38 acts fall into these two categories, while 25 were moderately or highly contentious. The correlation between higher contention and acts with a larger scope or effect under their 'class' classification is clear. Acts with a broader scope and effect were 
generally more contentious. There is no relevant delineation to be made along party lines. Both major parties presided over similar amounts of legislation in each type of class. While Labour and Labour-led governments presided over the passage of slightly more high contention legislation, the figures for legislation of low and no contention set against high and moderate contention yield similar results for each party.

Table 12 - Outcome v Class of Electoral and Electoral Amendment acts passed under National or National-led and Labour or Labour-led Governments 1927-2007

\begin{tabular}{|c|c|c|c|c|c|c|c|c|c|c|c|}
\hline \multirow{3}{*}{\multicolumn{2}{|c|}{$\begin{aligned} \mathbf{N} & =\text { National Govt } \\
\mathbf{L} & =\text { Labour Govt }\end{aligned}$}} & \multicolumn{10}{|c|}{ Outcome } \\
\hline & & \multicolumn{2}{|c|}{ Unanimous } & \multicolumn{2}{|c|}{$\begin{array}{c}\text { Not } \\
\text { Opposed }\end{array}$} & \multicolumn{2}{|c|}{$\begin{array}{l}\text { No Multi- } \\
\text { partisan } \\
\text { Support }\end{array}$} & \multicolumn{2}{|c|}{ Opposed } & \multicolumn{2}{|c|}{ Totals } \\
\hline & & $\mathbf{N}$ & $\mathbf{L}$ & $\mathbf{N}$ & $\mathrm{L}$ & $\mathbf{N}$ & $\mathrm{L}$ & $\bar{N}$ & $\mathrm{~L}$ & $\mathbf{N}$ & $\mathbf{L}$ \\
\hline \multirow{5}{*}{$\frac{\tilde{E}}{\tilde{v}}$} & Milestone & 1 & - & 1 & - & - & - & - & 1 & 2 & 1 \\
\hline & Major & 1 & - & 5 & 5 & 1 & - & 4 & 6 & 11 & 11 \\
\hline & Minor & 3 & 4 & 5 & 5 & 1 & - & 1 & 3 & 10 & 12 \\
\hline & Incidental & 2 & 1 & 7 & 6 & - & - & - & - & 9 & 7 \\
\hline & Total & 7 & 5 & 18 & 16 & 2 & - & 5 & 10 & 32 & 31 \\
\hline
\end{tabular}

Table 12 compares outcome and class of Act. The figures here clearly show that the New Zealand Parliament was, throughout the 1927 to 2007 period, more united than disunited on the electoral law. With 12 acts passed unanimously and 34 passed without an opposing vote in the House, only 15 were opposed. Even legislation of a major class was no more likely to be opposed than it was to be unopposed. Minor and incidental acts rarely resulted in a contested vote. Despite often fierce debate about the nature and effect of provisions, technicalities, and perceived omissions or 
unwelcome additions to the electoral law, government and opposition were, more often than not, united in terms of a 'big picture'.

\section{The Impact of Select Committees, Entrenchment and Consensus}

Chapter two discussed the conclusion of Bowler, Donovan and Karp that, while rational self-interest is a major feature of parties' attitudes to electoral institutions, attitudes about democracy and political ideology also have a role to play. ${ }^{328}$ Chapters three to six provided a number of examples of governments behaving in a non-selfinterested manner. The evidence in those chapters establishes that select committees, the entrenched nature of some electoral provisions, justifications of change based on a government's mandate, and the desirability of a consensual law-making in the electoral law area all affected the process by which electoral amendments were passed through the House. These factors are now considered in turn.

\section{Select Committees}

The role of select committees evolved dramatically in the period between 1937, when the Labour Government's Electoral Amendment Bill was referred to the Native Affairs Committee and became the first electoral bill referred to a select committee, and 1985, when Labour Member Jonathan Hunt said that select committees had come to play "an essential part in the way electoral legislation is dealt with in the House." ${ }^{329}$ The first major development was the establishment of the Electoral Act Committee to consider the Electoral Bill 1956. It successfully ironed out differences between the National and Labour parties, and produced a bill with unanimous support that introduced the constitutionally significant entrenched provisions into legislation.

\footnotetext{
${ }^{328}$ Bowler, Donovan \& Karp, 'Why Politicians Like Electoral Institutions: Self-Interest, Values or Ideology?', p. 434.

${ }^{329} 468$ NZPD 8632, 3 December 1985.
} 
As covered in chapter two, the next major development after 1956 was the establishment of the select committee on the Electoral Law in 1973, which served as an investigative body that could make recommendations to the government for subsequent implementation in legislation. The establishment of a committee that considered electoral matters before any legislation was drafted was an innovation. The 1973 example was followed in 1979. In both the early 1970s and early 1980s, electoral legislation emerged based on recommendations from committee.

The select committee process often fostered consensus. In 1981, Social Credit's Bruce Beetham, a member of the Electoral Law Select Committee, achieved a concession from the major parties to allow smaller parties to make submissions to the Representation Commission. This concession was then incorporated in legislation. Another example of the consensus forged by select committees is the Electoral Amendment Act 1983. National MP Simon Upton said in his speech on the first reading that the Bill had been introduced only after "a full and carefully considered report of a select committee that found tripartisan agreement from all present." 330 The 'legitimacy' of the 1983 Electoral Amendment Bill stemmed not from mandate theory or consensus in the debate in the House, but rather from decisions made by a committee acting in a non-partisan manner beforehand. This was an important development in the process by which electoral amendments are passed in New Zealand. Another example is the Electoral Amendment Act 1990, which contained changes which had the potential to be controversial. While its substantive changes related to the preparation of the electoral rolls and had been foreshadowed by the latest report of the Electoral Law Committee, it made a number of changes to other areas. For example, the form of the ballot paper was altered and election expense

\footnotetext{
${ }^{330} 455$ NZPD 3464, 27 October 1983.
} 
limits raised. National's Murray McCully, speaking for the Opposition on the report of the committee, said the committee was operated in a bipartisan fashion, and that is a model that could well be adopted in other proceedings of the House". 331

Another important example of the growing importance of the select committee process was the increasing willingness of governments to accede to the request of oppositions for the House to refer bills to select committee, when doing so had not necessarily been an original intention of the government. This first occurred during the debate over the Electoral Amendment Bill 1967, which allowed a candidate to stand in a European or Maori seat, regardless of the roll on which they were registered. This occurred also in the Electoral Amendment Bill 1979, which attempted to provide a temporary solution to the chaotic situation that had occurred with respect to electoral rolls at the 1978 general election. Governments did not only accede on significant electoral issues. In 1996, the government agreed to the demands of the opposition to move a motion in the House referring the Electoral Amendment Bill 1996 to select committee, although the bill merely amended a single printing error that had occurred in the preparation of the Electoral Amendment Act (No 2) 1995 for Royal Assent.

If the development of the select committee process increasingly encouraged consensus over the period studied, the entrenchment of certain provisions of the electoral law in 1956 forced consensus if change were to occur. Where consensus was unable to be found, the proposed legislation failed.

${ }^{331} 504$ NZPD 14513, 12 December 1989. 


\section{The Influence of Entrenchment}

Between 1956, when entrenchment was first inserted in the Electoral Act, and 2007, the entrenched provisions worked on a number of occasions in precisely the manner those who enacted it in 1956 had intended they would work, effectively ensuring bipartisan support for electoral amendment bills affecting entrenched provisions. The first piece of proposed legislation that saw the entrenchment provisions in action was the National Government's Electoral Amendment Bill 1966, examined in chapter five. In that case, despite a select committee process, the bill was withdrawn when it became clear that opposition support would not be forthcoming. In 1975, several clauses in the Electoral Amendment Bill were defeated during the committee stages because the government could not secure unanimity on some provisions.

The entrenchment provisions conferred significant political power on oppositions. In 1965 and 1980, for example, the Labour Opposition used entrenchment to its political advantage to pressurise government over changes in bills with which it disagreed. In 1980, it only informed the government at the last minute that it would in fact vote for the amendments to the entrenched provisions. In 1965, the mere threat of not supporting the amendment to an entrenched provision caused a lengthy debate in the House. The situation was not resolved until the government leveraged the power of the 'mandate argument' against the opposition.

\section{The Mandate as Justification}

If the most common criticism by oppositions of governments proposing amendments to the electoral law was self-interest, the most common justification used by governments in defence of those amendments was the power of the mandate. Holyoake's major criticism of the Labour Party's initial opposition to the Electoral 
Amendment Bill 1965 was that the government had a mandate from the electorate to make the change, as it had been signalled in its election manifesto. This argument was extended substantially by John Marshall, who said that the opposition had a “moral obligation" to support the government's changes. ${ }^{332}$ In 1950, the Labour opposition acknowledged that the National Government had the right to introduce legislation amending electoral boundary law because of its mandate from the 1949 election. $^{333}$

In 1934, Labour argued that the government could not change the length of the term as it had no mandate to do so. This argument had an interesting corollary, as it implied that, if the government had put the matter to the public in an election manifesto or otherwise, it would be entitled to pass the legislation with or without the support of the opposition. The government, however, on the most tenuous terms, claimed it had a mandate from the people for the extension of the term. Forbes claimed that the public had been forewarned of the government's intention to lengthen the parliamentary term by the 1932 Finance Act, the Act his government had passed to prolong its own term. ${ }^{334}$ His claim that there existed "a considerable body of public opinion favouring the longer term" was undermined by a later statement that it was the "duty" of Parliament to "give a lead" to the country in the matter. ${ }^{335}$ A similar argument arose around the Electoral Amendment Bill 1945. National argued that, as the change had not been signalled in the Labour Party's 1943 Election Manifesto, it was improper. In 1976 the National Government said that Hunt's private

\footnotetext{
${ }^{332} 343$ NZPD 1718, 5 August 1965.

333291 NZPD 2738, 27 September 1950.

334239 NZPD 143, 14 August 1934.

335239 NZPD 143, 14 August 1934.
} 
member's bill breached convention, as it had not been signalled in Labour's 1975 election manifesto.

The promise by an Opposition to repeal or further alter electoral law provisions was a common feature of contested electoral debates. Often, these promises were made in the House and then reiterated in election manifestos. Such occasions occurred in 1934, 1945, 1975 and 2007. In 1975, for example, senior National Members made clear signals of the party's intentions for the changes in the Electoral Amendment Act 1975 with which it disagreed. Brian Talboys said "[t]his 1975 Act will mark the division of opinion in the House, and that division will inevitably lead - and notice has been given of this - to further changes to the law on the change of government that I believe will take place at the end of this year." ${ }^{336}$ Incidentally, this was a move that disappointed some. National Member of Parliament Alan Highet was among those disappointed, evident in his statement to the House that the promise to alter the law on becoming government, while caused by the Rowling Government's Electoral bill, "does not lend itself to stable Government, and I very much regret this move." 337 In a sense, this "prior indication" procedure stands adjunct to the theory of the mandate.

\section{The Desirability of Consensus, Co-operation and Agreement}

Throughout the period studied, while the entrenched provisions effectively enforced unanimity on a number of occasions, the New Zealand Parliament was motivated often by a belief in the general desirability of consensus between parties. What Marshall called the 'spirit of 1956' extended, often voluntarily, to unentrenched

\footnotetext{
${ }^{336} 400$ NZPD 3777, 20 August 1975.

337398 NZPD 2146-47, 13 June 1975.
} 
provisions. This was especially strong for a 20-year period between 1956 and the Electoral Amendment Act 1975. It was still strongly present through until the end of the period studied, despite individual examples of legislation that did not manage to achieve consensus.

Often, this voluntary search for consensus took the form of consultation between governments and oppositions before the introduction of legislation. In 1948, Sidney Holland, then Leader of the Opposition, was consulted before the government introduced its Maori Roll legislation. The National and Labour parties reached agreement on the disqualification exemption acts passed between 1958 and 1963. Informal agreement was reached before legislation was introduced lowering the voting age to 18 in 1974. A number of examples of this exist in administration acts. In 1948, 1954 and 1972, the major parties worked together to find consensus before each bill was debated in the House. Other examples of voluntary consensus occurred in times of national crisis or substantial electoral change. During World War II, all electoral amendment acts, including those postponing elections and by-elections, and those preserving the rights of MPs (then fighting in the War) to retain their seats, all received unanimous support. In the years leading to the introduction of the MMP system, the government often used its majority in the House to allow private members bills to progress to select committee and sometimes to second reading, not because the government intended to support them through to third reading, but so they could contribute to a broader debate about the electoral system.

So the ideal of consensus or bi-partisanship or non-partisanship often served as a desirable goal for New Zealand politicians. In effect, the bipartisanship enforced by the entrenched provisions transferred, at times, into a 'best practice' for other areas of 
electoral law change. It would not tell the whole story of New Zealand's electoral law, however, to presume altruism and efforts to behave in a non-partisan manner are accurate descriptions of all electoral law change.

\section{Motivations: Self Interest and Partisanship}

It is a clear finding from the chapters above that the National and Labour parties worked best together on changes to the electoral law that benefited either major parties, or disadvantaged minor parties. There are at least five relevant examples of this. In 1937, both parties voted to raise the deposit for candidates for election, effectively discouraging minor candidates from standing. In 1978, both parties voted against Beetham's bill that sought to gain representation on the Representation Commission for minor parties. In 1986 both parties voted against similar legislation introduced by NZDemocrats' MP Garry Knapp. In 1995, both parties overrode the concerns of minor parties in order to alter the layout of the ballot paper and ensure the party and electorate vote columns were aligned. The minor parties believed this discouraged split voting, and thus provided an advantage to the major parties. Finally, in 1996, National and Labour combined to allow each party to appoint representatives to the Broadcasting Commission, which decided allocations for electoral broadcasting.

The New Zealand example, then, provides an addition to Boix' argument that "[a]nticipating the coordinating consequences of electoral rules, any current Government (provided it has the monopoly over electoral rulemaking) shapes the electoral rules to its advantage." ${ }^{, 33}$ In New Zealand, many governments and major

\footnotetext{
${ }^{338}$ Boix, 'Setting the Rules of the Game: The Choice of Electoral Systems in Advanced Democracies', p. 609.
} 
opposition parties shaped the electoral laws to their dual advantage, and to the potential disadvantage of minor parties. Yet the story that emerges from chapters three to six is, for all its moments of consensus, often a tale of contention, disagreement, dissent and adversarial politics. Furthermore, the accusation of selfinterest formed the major criticism by oppositions of governments changing the electoral law across the entire period studied. As outlined earlier in this chapter, on a number of issues, such as the franchise, electoral boundaries and the date on which rolls should close, the National and Labour parties divided in opinion many times. In some examples, such as the Coalition Government's extension of its own life in 1932, it is easy to suggest self-interest as a motivation. In other areas it is harder. The veracity and constancy throughout the period of the arguments between the major parties on issues such as the closure of the rolls, however, strongly suggest that a party will defend, or seek to extend, any perceived advantage inherent in electoral legislation.

Chapter two introduced Andrews and Jackman's argument that, while party leaders attempt to behave strategically, it is not clear how they can do so effectively when they are faced with uncertainty about outcomes. ${ }^{339}$ The New Zealand example provides some support for this argument. First, governments sometimes miscalculated. A prime example of this is the Electoral Amendment Act 1934, where an already unpopular group of governing parties, which the following year went from holding 48 seats to 19 , successfully introduced a law extending the term of future Parliaments to four years. The risk for a government is that making a change for its own benefit may equally help the opposition once it enters government. There are two further interesting examples of this. During the passage of the Electoral Bill

\footnotetext{
${ }^{339}$ Andrews and Jackman, 'Strategic Fools: Electoral Rule Choice Under Extreme Uncertainty’, p. 82.
} 
1956, the Labour Party's complaints about the government's political appointments to the Representation Commission, and Labour's subsequent advocacy of a reformed, impartial, Representation Commission was the reverse position to that taken by the previous Labour Government. The politicisation of the Commission had occurred due to changes made under Labour in the Electoral Amendment Act 1945.

The Electoral Amendment Act 1945 provides another example of a common dilemma that faces a government amending the electoral law. Given that most changes to the law under which parties are elected to government are going to generate at least some level of debate, a government must balance protecting or strengthening its current electoral position (or indeed, weakening its opposition's position) with the risk of appearing self-interested to the public. It must balance the prospect of an electoral pay-off with the prospect of a backlash. This is not to argue that all changes to the electoral law are motivated by self-interest. Because of the special nature of electoral law, however, governments will have an interest in not being seen as self-interested by the public. Issues of public perception are especially relevant when electoral change is effected close to election year. Labour MP Richard Prebble raised an interesting argument around this point in 1977 when he said: ${ }^{340}$

I ask the Government, through you, Mr Speaker, why it has brought in this partisan electoral Bill. There have been changes in electoral Bills before. In 1934 the Forbes-Coates Government postponed an election for a year, and it was thrown out. In 1946 the Labour Government foolishly decided to get rid of the country quota, and it was thrown out. In 1956 the National Government decided to change the electoral laws, and at the next election it was thrown out. In 1975 the Labour Government changed the electoral laws, for reasons which were misunderstood, and it was thrown out.

Labour actually retained office (albeit with a substantially reduced majority) at the 1946 General Election. Nonetheless, Prebble's analysis illustrates the balancing act

${ }^{340} 416$ NZPD 5147, 7 December 1977. 
of protecting or extending an advantage, and yet not appearing self-interested to the public, that faces a government introducing an electoral amendment. Legislation introduced by a new government to repeal changes to the electoral law made by a previous government almost always has been partisan. The Labour Government's 1937 Electoral Amendment Act serves as one of the first examples of a government carrying through a threat to repeal a previous government's electoral legislation. Rex Mason set out the government's motivation in changing the parliamentary term, including the current term, back to three years: ${ }^{341}$

\begin{abstract}
Whatever may be thought as to the question of the proper life of Parliament, as far as this Government is concerned, it believes that Parliament is a trustee for the people and should not enlarge the life of Parliament except in so far as the people have definitely assented to that enlargement. Pursuant to that view, the Government is taking steps to restore to the people the right which they previously had, a right which, it seems to this Government, was wrongly taken from the people.
\end{abstract}

While it is tempting, perhaps, to characterise such moves as altruistic, as outlined in chapter four, there is an argument to be made that oppositions that promise repeal are then politically bound to carry through on those promises. In both 1934 and 2007, both opposition parties had already played an adversarial and partisan role, and made political capital out of unpopular moves by the government of the time. Once in power, they then had to follow through on their pre-election pledges.

\title{
Three 'Eras' of Electoral Change?
}

It is clear that both self-interest and other factors influenced electoral change in New Zealand between 1927 and 2007. As a final piece of analysis, I suggest the history of the period can be separated into three broad, yet distinct, 'eras'.

\footnotetext{
341249 NZPD 811, 30 November 1937.
} 


\section{1927 - 1955 Consensus Absent?}

From the start of the period studied to the year before the passage of the Electoral Act 1956, any preference for changes to the electoral law to be bi-partisan had not yet developed. The period saw the passage through Parliament of a number of highly controversial acts, none of which involved any suggestion of consensus, such as the Finance Act 1932 and the Electoral Amendment Act 1934, which extended the parliamentary term, and the Electoral Amendment Act 1945, which abolished the country quota and introduced political representation onto the Representation Commission.

\section{1956 - 1974 Consensus Gained?}

The second 'era' began with the Electoral Act 1956, which was significant both for the entrenchment provisions it contained, and for the consensual process by which it was passed through Parliament. The entrenchment clauses provided a legislative requirement for unanimity on some electoral amendments; an 'ideal' of consensus, however, spilled over into non-entrenched areas. This was generally a period that saw disagreements worked over and compromise sought. Parties, however, did not always agree on the detail. The failed Electoral Amendment Bill 1966 provides an example of the entrenchment provisions in action. Furthermore, the debate over the Electoral Amendment Bill 1965, which altered the number of parliamentary seats, shows that some electoral legislation was sometimes still highly contested. Robinson was correct, however, when he wrote in 1970 that: "[t]he Electoral Act 1956 has had the effect of modifying the partisan nature of electoral reform and of promoting the search for a wider degree of consensus than had previously been the case." ${ }^{342}$

\footnotetext{
${ }^{342}$ Robinson, 'Parliament in New Zealand', pp. 142-143.
} 


\section{3. $1975-2007$ Consensus Maintained?}

John Marshall, who, as Attorney-General and Minister of Justice, spearheaded the entrenchment provisions in 1956, bemoaned the breakdown in consensus that occurred in 1975, saying "it is highly desirable that the effort should be made to get back to the position which prevailed in 1956, when both sides were prepared to make concessions to the other, and an acceptable balance of interests and advantage was achieved. ${ }^{\text {343 }}$ The example of the Electoral Amendment Act 1975 certainly presents a breakdown in consensus. The question, however, is the extent to which the period after 1975 was coloured by the Act or by the same factors that caused the contention surrounding it.

The 1956 to 1974 period saw two decades of an almost uninterrupted search for consensus on electoral amendment legislation. In this sense, the period after 1975 cannot be compared to the earlier period. The later period certainly saw its share of bills with broad consensus. The administrative amendments of the early 1980s and amendment acts of the early 1990s all enjoyed unanimous support in the House. The period was also, however, punctuated by bills introduced by governments and passed through the House in the face of major opposition. These included the Electoral Finance Act 2007, the electoral broadcasting legislation of the late 1980s, partyhopping legislation and a number of bills altering the residential requirement and the closing date for enrolment. Nonetheless, the active search for consensus that had built up since 1956 maintained a level of influence throughout the post-1975 era. It was further bolstered by the further development of the select committee system and the permanent Electoral Law committee. It was certainly present in the comments of

\footnotetext{
${ }^{343}$ Marshall in The Reform of Parliament, p. 11.
} 
National MP Wayne Mapp and Labour Leader Phil Goff in the aftermath of the Electoral Finance Act 2007. ${ }^{344}$

${ }^{344}$ See comments above at n 4 and n 5. 


\section{Chapter Eight Conclusion}

Throughout the 1927 to 2007 period Parliament was more often united than disunited on matters concerning the electoral law. This thesis established that select committees, the entrenched nature of some electoral provisions, justifications of change based on a government's mandate, and the desirability of consensual lawmaking in the electoral law area all affected the process by which electoral amendments were passed through the House. The select committee process often fostered consensus, while the entrenched provisions often forced consensus. In the entrenched areas, where consensus was unable to be found, proposed legislation failed. The bi-partisan approach to changing the electoral law in New Zealand emerged under the National Government in the 1950s. The desirability of consensus in the area remained strong in the arguments put forward in the House by National Party Members of Parliament throughout the period after 1956. The Labour Party also had individual Members of Parliament who strongly promoted the bi-partisan approach, such as Jonathan Hunt and David Lange.

Where consensus was not present (and, occasionally, when it was), changes were most often justified by governments on the basis of an election mandate from the public. Oppositions most often attacked these changes as being self-interested. Selfinterest was also an important factor in some change. In government, both major parties introduced legislation that benefited themselves, disadvantaged their opponents, or combined these two goals. On a number of occasions, the parties worked together on changes to the electoral law that benefited the major parties or disadvantaged minor parties. 
In the analysis, several interesting issues emerged that were beyond the scope of the thesis and could be worthy of further exploration. One of these is the argument that a link can be made between unpopular governments and self-serving electoral legislation. The history of the 1927-2007 period provides a number of examples of governments passing controversial electoral reform laws in the year of, or in the year before, a General Election and losing office. Another question is whether the examination of consensus in the electoral law undertaken in this thesis could be extended to other areas of legislation. The role of consensus in Treaty of Waitangi settlements could be especially fruitful. Another exploration could involve extending the focus from the period studied to the period since the New Zealand Parliament first sat, including electoral law amendments such as the extension of the franchise to women. International comparisons could also be of interest, especially with those countries who most closely share New Zealand's constitutional heritage - Australia, Canada and the United Kingdom.

As an overall conclusion, then, although self-interest is an adequate explanation for much electoral law change in New Zealand, behaviour during 1927 to 2007 was also influenced by the select committee process, the entrenched provisions and a general acceptance among parties that changes to the electoral law should be, so far as possible, consensual and cooperative. Overall, it is too simplistic to make a general observation that amendments to the electoral law are invariably exclusively selfinterested or that they always occur as a result of co-operation and consensus. There are examples of either set of motivations at work and, on occasion, examples of both in action at the same time. Using the perspective provided by the history of the 1927 to 2007 period, more recent acts, such as the Electoral Finance Act 2007, can be viewed through a broader lens. At the time of the submission of this thesis, the 
National Government was embarking on a programme of electoral reform. An electoral issues paper produced by the Ministry of Justice outlined a number of contentious issues, ${ }^{345}$ especially surrounding electoral finance reform, and public meetings were held around the country.

Most significantly, perhaps, the government included in its 2008 General Election manifesto a promise to hold a referendum on the MMP system at the 2011 General Election. The electoral law in New Zealand is set to remain an area of continuing activity.

${ }^{345}$ See http://www.justice.govt.nz/policy-and-consultation/electoral/electoral-financereform/documents/issues-paper-FINAL.pdf 


\section{Appendix A}

\section{Acts Affecting the Electoral Law 1927 - 2007 (in chronological order)}

\begin{tabular}{|c|c|c|c|c|c|c|c|c|c|c|c|}
\hline Year & Name & $\begin{array}{c}\text { Government } \\
\text { and Prime } \\
\text { Minister }\end{array}$ & Effect & Area & Class & Contention & $\begin{array}{c}\text { Prior } \\
\text { Consultation } \\
\text { Between } \\
\text { Major Parties }\end{array}$ & $\begin{array}{c}\text { Legislative } \\
\text { Outcome }\end{array}$ & $\begin{array}{c}\text { Select } \\
\text { Committee }\end{array}$ & $\begin{array}{l}\text { Amended } \\
\text { Entrenched } \\
\text { Provisions }\end{array}$ & $\begin{array}{c}\text { Repealed } \\
\text { Previous } \\
\text { Amendment }\end{array}$ \\
\hline 1927 & $\begin{array}{c}\text { Electoral } \\
\mathrm{Act}^{346}\end{array}$ & $\begin{array}{l}\text { Reform } \\
\text { Coates }\end{array}$ & Amalgamating & Technical & Minor & None & No & Unanimous & No & N/A & N/A \\
\hline 1932 & Finance Act $^{347}$ & $\begin{array}{c}\text { Coalition } \\
\text { Forbes }\end{array}$ & Circumventing & Term Length & Major & High & No & Opposed & No & N/A & No \\
\hline 1934 & $\begin{array}{c}\text { Electoral } \\
\text { Amendment } \\
\mathrm{Act}^{348}\end{array}$ & $\begin{array}{l}\text { Coalition } \\
\text { Forbes }\end{array}$ & Amending & Term Length & Major & High & No & Opposed & No & N/A & No \\
\hline 1937 & $\begin{array}{l}\text { Electoral } \\
\text { Amendment } \\
\text { Act }^{349}\end{array}$ & $\begin{array}{l}\text { Labour } \\
\text { Savage }\end{array}$ & Amending & $\begin{array}{l}\text { Term Length; } \\
\text { Maori }\end{array}$ & Major & Low & No & Not Opposed & $\begin{array}{l}\text { Native } \\
\text { Affairs }\end{array}$ & N/A & $\begin{array}{l}\text { Yes } \\
(1934)\end{array}$ \\
\hline
\end{tabular}

\footnotetext{
${ }^{346}$ Amalgamated existing Electoral law in a single statute

${ }^{347}$ Extended the term of the current Parliament from three to four years

${ }^{348}$ Extended the term of all future Parliaments from three to four years

${ }^{349}$ Set parliamentary term back to three years. Extended the secret ballot and other practices involved with the general roll to Maori.
} 


\begin{tabular}{|c|c|c|c|c|c|c|c|c|c|c|c|}
\hline Year & Name & $\begin{array}{c}\text { Government } \\
\text { and Prime } \\
\text { Minister }\end{array}$ & Effect & Area & Class & Contention & $\begin{array}{c}\text { Prior } \\
\text { Consultation } \\
\text { Between } \\
\text { Major Parties }\end{array}$ & $\begin{array}{l}\text { Legislative } \\
\text { Outcome }\end{array}$ & $\begin{array}{c}\text { Select } \\
\text { Committee }\end{array}$ & $\begin{array}{l}\text { Amended } \\
\text { Entrenched } \\
\text { Provisions }\end{array}$ & $\begin{array}{c}\text { Repealed } \\
\text { Previous } \\
\text { Amendment }\end{array}$ \\
\hline 1940 & $\begin{array}{l}\text { Electoral } \\
\text { Amendment } \\
\text { Act }^{350}\end{array}$ & $\begin{array}{l}\text { Labour } \\
\text { Fraser }\end{array}$ & Amending & $\begin{array}{c}\text { Franchise and } \\
\text { Registration; } \\
\text { MP } \\
\text { Qualification }\end{array}$ & Minor & None & No & Unanimous & No & N/A & No \\
\hline 1941 & $\begin{array}{l}\text { Prolongation } \\
\text { of Parliament } \\
\mathrm{Act}^{351}\end{array}$ & $\begin{array}{l}\text { Labour } \\
\text { Fraser }\end{array}$ & Circumventing & Term Length & Minor & None & Yes & Unanimous & No & N/A & No \\
\hline 1942 & $\begin{array}{l}\text { Prolongation } \\
\text { of Parliament } \\
\mathrm{Act}^{352}\end{array}$ & $\begin{array}{l}\text { Labour } \\
\text { Fraser }\end{array}$ & Circumventing & Term Length & Minor & Low & Yes & $\underset{353}{\text { Unanimous }}$ & No & N/A & No \\
\hline 1943 & $\begin{array}{l}\text { By-elections } \\
\text { Postponement } \\
\text { Act }^{354}\end{array}$ & $\begin{array}{l}\text { Labour } \\
\text { Fraser }\end{array}$ & Circumventing & By-election & Incidental & None & No & Unanimous & No & N/A & N/A \\
\hline 1945 & $\begin{array}{c}\text { Electoral } \\
\text { Amendment } \\
\text { Act }^{355}\end{array}$ & $\begin{array}{l}\text { Labour } \\
\text { Fraser }\end{array}$ & Amending & $\begin{array}{l}\text { Boundaries; } \\
\text { Franchise and } \\
\text { Registration }\end{array}$ & Milestone & High & No & Opposed & No & N/A & No \\
\hline
\end{tabular}

${ }^{350}$ Extended the franchise to all members of the forces serving New Zealand. Preserved the rights of MPs and Legislative Councillors serving in World War II.

${ }^{351}$ Delayed the election by a year, due to World War II.

${ }^{352}$ Delayed the election by a further year.

${ }^{353}$ Three members - Doidge, Atmore and Lee - supported an amendment for a committee to examine public opinion to the Bill. It was defeated and the Bill's third reading was unanimously supported.

${ }^{354}$ Prevented the holding of any by-elections until the next general election.

${ }^{355}$ Abolished the country quota. Altered composition of Representation Commission. Based boundary calculations on adult population instead of total population. 


\begin{tabular}{|c|c|c|c|c|c|c|c|c|c|c|c|}
\hline Year & Name & $\begin{array}{c}\text { Government } \\
\text { and Prime } \\
\text { Minister }\end{array}$ & Effect & Area & Class & Contention & $\begin{array}{c}\text { Prior } \\
\text { Consultation } \\
\text { Between } \\
\text { Major Parties }\end{array}$ & $\begin{array}{c}\text { Legislative } \\
\text { Outcome }\end{array}$ & $\begin{array}{c}\text { Select } \\
\text { Committee }\end{array}$ & $\begin{array}{l}\text { Amended } \\
\text { Entrenched } \\
\text { Provisions }\end{array}$ & $\begin{array}{c}\text { Repealed } \\
\text { Previous } \\
\text { Amendment }\end{array}$ \\
\hline 1948 & $\begin{array}{c}\text { Electoral } \\
\text { Amendment } \\
\text { Act }^{356}\end{array}$ & $\begin{array}{l}\text { Labour } \\
\text { Fraser }\end{array}$ & Amending & $\begin{array}{c}\text { Administration; } \\
\text { Electioneering } \\
\text { \& Finance; } \\
\text { Maori }\end{array}$ & Minor & None & No & Not Opposed & No & N/A & No \\
\hline 1950 & $\begin{array}{c}\text { Electoral } \\
\text { Amendment } \\
\text { Act }^{357}\end{array}$ & $\begin{array}{l}\text { National } \\
\text { Holland }\end{array}$ & Amending & $\begin{array}{l}\text { Boundaries; } \\
\text { Franchise and } \\
\text { Registration }\end{array}$ & Major & Moderate & No & Opposed & No & N/A & $\begin{array}{c}\text { Yes } \\
(1945)\end{array}$ \\
\hline 1953 & $\begin{array}{c}\text { Electoral } \\
\text { Amendment } \\
\mathrm{Act}^{358}\end{array}$ & $\begin{array}{l}\text { National } \\
\text { Holland }\end{array}$ & Amending & $\begin{array}{l}\text { Administration; } \\
\text { Boundaries; } \\
\text { Maori }\end{array}$ & Incidental & None & No & Not Opposed & No & N/A & No \\
\hline 1954 & $\begin{array}{c}\text { Electoral } \\
\text { Amendment } \\
\text { Act }^{359}\end{array}$ & $\begin{array}{l}\text { National } \\
\text { Holland }\end{array}$ & Amending & $\begin{array}{l}\text { Administration; } \\
\text { Technical }\end{array}$ & Incidental & Low & No & Not Opposed & No & N/A & No \\
\hline 1954 & $\begin{array}{c}\text { Patea By- } \\
\text { Election Act }\end{array}$ & $\begin{array}{l}\text { National } \\
\text { Holland }\end{array}$ & Circumventing & $\begin{array}{l}\text { Administration; } \\
\text { By-election }\end{array}$ & Incidental & Low & No & Not Opposed & No & N/A & No \\
\hline
\end{tabular}

\footnotetext{
${ }^{356}$ Provided legislative authority for the compilation of Maori electoral rolls.

${ }^{357}$ Reverted boundary calculations to a total population base, among other changes.

${ }^{358}$ Short, technical act dealing with Maori boundaries and roll preparation.

${ }^{359}$ Removed ambiguity in Electoral Act 1927 dealing with by-elections and the vacancy of seats. Technical change to special voting procedures.

${ }^{360}$ Removed a further ambiguity in the Electoral Act 1927 that had led to a disagreement between Crown Law and the Speaker as to when a vacancy needed to be gazetted.
} 


\begin{tabular}{|c|c|c|c|c|c|c|c|c|c|c|c|}
\hline Year & Name & $\begin{array}{c}\text { Government } \\
\text { and Prime } \\
\text { Minister }\end{array}$ & Effect & Area & Class & Contention & \begin{tabular}{|c|} 
Prior \\
Consultation \\
Between \\
Major Parties
\end{tabular} & $\begin{array}{c}\text { Legislative } \\
\text { Outcome }\end{array}$ & $\begin{array}{c}\text { Select } \\
\text { Committee }\end{array}$ & $\begin{array}{c}\text { Amended } \\
\text { Entrenched } \\
\text { Provisions }\end{array}$ & $\begin{array}{c}\text { Repealed } \\
\text { Previous } \\
\text { Amendment }\end{array}$ \\
\hline 1956 & $\begin{array}{l}\text { Electoral } \\
\text { Act }^{361}\end{array}$ & $\begin{array}{l}\text { National } \\
\text { Holland }\end{array}$ & $\begin{array}{c}\text { Original; } \\
\text { Amending; } \\
\text { Amalgamating }\end{array}$ & $\begin{array}{l}\text { Administration; } \\
\text { Boundaries; } \\
\text { Constitution; } \\
\text { Electioneering } \\
\text { and Finance; } \\
\text { Franchise and } \\
\text { Registration; } \\
\text { Maori; } \\
\text { Method of } \\
\text { Voting; } \\
\text { MP } \\
\text { Qualification }\end{array}$ & Milestone & Low & Yes & Unanimous & Electoral Bill & N/A & No \\
\hline 1958 & Finance $\mathrm{Act}^{362}$ & $\begin{array}{l}\text { Labour } \\
\text { Nash }\end{array}$ & Circumventing & $\begin{array}{c}\text { MP } \\
\text { Qualification }\end{array}$ & Incidental & None & Yes & Not Opposed & No & No & No \\
\hline 1958 & $\begin{array}{c}\text { Electoral } \\
\text { Amendment } \\
\mathrm{Act}^{363}\end{array}$ & $\begin{array}{l}\text { Labour } \\
\text { Nash }\end{array}$ & Amending & $\begin{array}{c}\text { MP } \\
\text { Qualification }\end{array}$ & Incidental & None & No & Not Opposed & No & No & No \\
\hline
\end{tabular}

\footnotetext{
${ }^{361}$ Consolidated and amended the Electoral Act 1927 and its many amendments. Introduced entrenched provisions. Reverted Representation Commission to apolitical structure. ${ }^{362}$ Prevented disqualification provisions of the Electoral Act 1956 applying to any payment received by Hon William Fox as a member of the Workers' Compensation Board

anytime before 1 October 1958.
Altered the definition of 'contractor'.
} 


\begin{tabular}{|c|c|c|c|c|c|c|c|c|c|c|c|}
\hline Year & Name & $\begin{array}{c}\text { Government } \\
\text { and Prime } \\
\text { Minister }\end{array}$ & Effect & Area & Class & Contention & $\begin{array}{c}\text { Prior } \\
\text { Consultation } \\
\text { Between } \\
\text { Major Parties }\end{array}$ & $\begin{array}{c}\text { Legislative } \\
\text { Outcome }\end{array}$ & $\begin{array}{c}\text { Select } \\
\text { Committee }\end{array}$ & $\begin{array}{l}\text { Amended } \\
\text { Entrenched } \\
\text { Provisions }\end{array}$ & $\begin{array}{c}\text { Repealed } \\
\text { Previous } \\
\text { Amendment }\end{array}$ \\
\hline 1959 & $\begin{array}{l}\text { Electoral } \\
\text { Amendment } \\
\text { Act }^{364}\end{array}$ & $\begin{array}{l}\text { Labour } \\
\text { Nash }\end{array}$ & Amending & Technical & Incidental & None & No & Not Opposed & No & No & No \\
\hline 1960 & $\begin{array}{l}\text { Electoral } \\
\text { Amendment } \\
\text { Act }^{365}\end{array}$ & $\begin{array}{l}\text { Labour } \\
\text { Nash }\end{array}$ & Amending & Administration & Minor & Low & Yes & Unanimous & No & No & No \\
\hline 1960 & $\begin{array}{c}\text { Political } \\
\text { Disabilities } \\
\text { Removal } \\
\text { Act }^{366}\end{array}$ & $\begin{array}{l}\text { Labour } \\
\text { Nash }\end{array}$ & $\begin{array}{l}\text { Amending; } \\
\text { Original }\end{array}$ & $\begin{array}{l}\text { Electioneering } \\
\text { and Finance }\end{array}$ & Major & High & No & Opposed & No & No & $\begin{array}{c}\text { Yes } \\
(1950)\end{array}$ \\
\hline 1960 & Finance $\mathrm{Act}^{367}$ & $\begin{array}{l}\text { Labour } \\
\text { Nash }\end{array}$ & Circumventing & $\begin{array}{c}\text { MP } \\
\text { Qualification }\end{array}$ & Incidental & Low & No & Not Opposed & No & No & No \\
\hline 1961 & Finance $\mathrm{Act}^{368}$ & $\begin{array}{l}\text { National } \\
\text { Holyoake }\end{array}$ & Circumventing & $\begin{array}{c}\text { MP } \\
\text { Qualification }\end{array}$ & Incidental & None & No & Not Opposed & No & No & No \\
\hline
\end{tabular}

${ }_{364}^{364}$ Made a minor change in the name of an organization.

365 Allowed for use of a photographic process in the preparation of electoral rolls.

${ }^{366}$ Restored ability of unions to make levies for political purposes. The Savage Government had introduced such a measure in 1936 but Holland's National administration had repealed it in 1950.

${ }^{367}$ Prevented the disqualification of Reginald Keeling MP due to payments received for attendance at a conference.

${ }^{368}$ Prevented the disqualification of William Brown MP due to payments received for the chairing of boards. 


\begin{tabular}{|c|c|c|c|c|c|c|c|c|c|c|c|}
\hline Year & Name & $\begin{array}{c}\text { Government } \\
\text { and Prime } \\
\text { Minister }\end{array}$ & Effect & Area & Class & Contention & \begin{tabular}{|c|} 
Prior \\
Consultation \\
Between \\
Major Parties
\end{tabular} & $\begin{array}{c}\text { Legislative } \\
\text { Outcome }\end{array}$ & $\begin{array}{c}\text { Select } \\
\text { Committee }\end{array}$ & $\begin{array}{l}\text { Amended } \\
\text { Entrenched } \\
\text { Provisions }\end{array}$ & $\begin{array}{c}\text { Repealed } \\
\text { Previous } \\
\text { Amendment }\end{array}$ \\
\hline 1963 & $\begin{array}{c}\text { Electoral } \\
\text { Amendment } \\
\text { Act }^{369}\end{array}$ & $\begin{array}{l}\text { National } \\
\text { Holyoake }\end{array}$ & Amending & $\begin{array}{c}\text { MP } \\
\text { Qualification }\end{array}$ & Minor & None & No & Not Opposed & No & No & No \\
\hline 1965 & $\begin{array}{c}\text { Electoral } \\
\text { Amendment } \\
\mathrm{Act}^{370}\end{array}$ & $\begin{array}{l}\text { National } \\
\text { Holyoake }\end{array}$ & Amending & $\begin{array}{c}\text { Boundaries; } \\
\text { Number of MPs }\end{array}$ & Major & High & Yes & Not Opposed & $\begin{array}{l}\text { Statutes } \\
\text { Revision }\end{array}$ & Yes & No \\
\hline 1967 & $\begin{array}{c}\text { Electoral Poll } \\
\mathrm{Act}^{371}\end{array}$ & $\begin{array}{l}\text { National } \\
\text { Holyoake }\end{array}$ & Original & Referendum & Minor & None & Yes & Unanimous & $\begin{array}{l}\text { Statutes } \\
\text { Revision }\end{array}$ & No & No \\
\hline 1967 & $\begin{array}{c}\text { Electoral } \\
\text { Amendment } \\
\mathrm{Act}^{372}\end{array}$ & $\begin{array}{l}\text { National } \\
\text { Holyoake }\end{array}$ & Amending & $\begin{array}{c}\text { Administration; } \\
\text { Franchise and } \\
\text { Registration; } \\
\text { Maori }\end{array}$ & Major & Low & Yes & Not Opposed & $\begin{array}{l}\text { Maori } \\
\text { Affairs }\end{array}$ & No & No \\
\hline
\end{tabular}

\footnotetext{
${ }^{369}$ Introduced as part of a Statutes Amendment Bill and did two things. First, it further amended the troublesome definition of 'contractor' from the 1956 Electoral Act. This gave an MP, upon his election to Parliament and before sitting as a member, one month in which to disclaim the contract and any payment made (accidentally presumably) after that disclamation, will not stop him from continuing to hold office. The Act also repealed subsection 43(7) of the Electoral Act 1956. That provision had stated: "The burden of proving that a person against whom proceedings are taken for an offence against this section was not qualified to be registered as an elector at any material time shall be on that person."

${ }^{370}$ Gave effect to the Government's election promise to fix the parliamentary representation for the South Island at 25 seats. The quota of North Island seats was to be worked out from the South Island number. Maori representation was left untouched.

${ }^{371}$ Allowed for a referendum on the length of the parliamentary term to take place concurrently with the Sale of Liquor referendum.

372 Allowed a candidate to stand in a European or Maori seat, regardless of the roll on which they were registered. Repealed section 97 of the Electoral Act 1956 (as amended by the Sale of Liquor Act 1962). This allowed the sale of liquor on election day.
} 


\begin{tabular}{|c|c|c|c|c|c|c|c|c|c|c|c|}
\hline Year & Name & $\begin{array}{l}\text { Government } \\
\text { and Prime } \\
\text { Minister }\end{array}$ & Effect & Area & Class & Contention & $\begin{array}{c}\text { Prior } \\
\text { Consultation } \\
\text { Between } \\
\text { Major Parties }\end{array}$ & $\begin{array}{c}\text { Legislative } \\
\text { Outcome }\end{array}$ & $\begin{array}{c}\text { Select } \\
\text { Committee }\end{array}$ & $\begin{array}{c}\text { Amended } \\
\text { Entrenched } \\
\text { Provisions }\end{array}$ & $\begin{array}{c}\text { Repealed } \\
\text { Previous } \\
\text { Amendment }\end{array}$ \\
\hline 1969 & $\begin{array}{c}\text { By-Elections } \\
\text { Postponement } \\
\text { Act }^{373}\end{array}$ & $\begin{array}{l}\text { National } \\
\text { Holyoake }\end{array}$ & Circumventing & By-election & Incidental & None & Yes & Not Opposed & No & No & No \\
\hline 1969 & $\begin{array}{l}\text { Electoral } \\
\text { Amendment } \\
\text { Act }^{374}\end{array}$ & $\begin{array}{l}\text { National } \\
\text { Holyoake }\end{array}$ & Amending & $\begin{array}{l}\text { Franchise and } \\
\text { Registration }\end{array}$ & Major & Moderate & No & Not Opposed & No & Yes & No \\
\hline 1969 & $\begin{array}{c}\text { Electoral } \\
\text { Amendment } \\
\text { Act (No 2) }\end{array}$ & $\begin{array}{l}\text { National } \\
\text { Holyoake }\end{array}$ & Amending & Administration & Incidental & Low & Yes & Not Opposed & $\begin{array}{l}\text { Statutes } \\
\text { Revision }\end{array}$ & No & No \\
\hline 1971 & $\begin{array}{l}\text { Electoral } \\
\text { Amendment } \\
\mathrm{Act}^{376}\end{array}$ & $\begin{array}{l}\text { National } \\
\text { Holyoake }\end{array}$ & Amending & $\begin{array}{l}\text { Administration; } \\
\text { Electioneering } \\
\text { and Finance; } \\
\text { Franchise and } \\
\text { Registration; }\end{array}$ & Minor & Moderate & Yes & Not Opposed & $\begin{array}{c}\text { Public } \\
\text { Expenditure }\end{array}$ & No & No \\
\hline
\end{tabular}

\footnotetext{
${ }^{373}$ Delayed the holding of by-elections to the time of the general election, which was only weeks away.

${ }^{374}$ Lowered the voting age from 21 to 20

${ }^{375}$ Made a minor administrative change to the law surrounding the position of polling booths on electorate boundaries.

${ }^{376}$ A reasonably substantial amendment bill, which dealt with a number of issues, including altering voting roll printing procedure for electors resident in the Chatham Islands; updating the provision that disqualified electors who were in prison, or had serious mental illness or insanity, to cover a grey area between the two; updating the language used in the Electoral Amendment Bill (No 2) 1969, allowing suitable polling places to be appointed as polling places for two districts; updating the Electoral Act 1956 provisions concerning scrutineers, to allow for, and regulate the situation of, more than one scrutineer at a polling booth and increasing the maximum amount of election expenses from $\$ 1000$ to $\$ 1500$.
} 


\begin{tabular}{|c|c|c|c|c|c|c|c|c|c|c|c|}
\hline Year & Name & $\begin{array}{c}\text { Government } \\
\text { and Prime } \\
\text { Minister }\end{array}$ & Effect & Area & Class & Contention & $\begin{array}{c}\text { Prior } \\
\text { Consultation } \\
\text { Between } \\
\text { Major Parties }\end{array}$ & $\begin{array}{c}\text { Legislative } \\
\text { Outcome }\end{array}$ & $\begin{array}{c}\text { Select } \\
\text { Committee }\end{array}$ & $\begin{array}{l}\text { Amended } \\
\text { Entrenched } \\
\text { Provisions }\end{array}$ & $\begin{array}{c}\text { Repealed } \\
\text { Previous } \\
\text { Amendment }\end{array}$ \\
\hline 1972 & $\begin{array}{c}\text { Electoral } \\
\text { Amendment } \\
\text { Act }^{377}\end{array}$ & $\begin{array}{l}\text { National } \\
\text { Marshall }\end{array}$ & Amending & Administration & Incidental & None & Yes & Unanimous & No & No & No \\
\hline 1974 & $\begin{array}{c}\text { Electoral } \\
\text { Amendment } \\
\mathrm{Act}^{378}\end{array}$ & $\begin{array}{l}\text { Labour } \\
\text { Rowling }\end{array}$ & Amending & $\begin{array}{l}\text { Franchise and } \\
\text { Registration }\end{array}$ & Major & None & Yes & Not Opposed & Electoral Act & Yes & Yes \\
\hline 1975 & $\begin{array}{c}\text { Electoral } \\
\text { Amendment } \\
\mathrm{Act}^{379}\end{array}$ & $\begin{array}{l}\text { Labour } \\
\text { Rowling }\end{array}$ & Amending & $\begin{array}{l}\text { Administration; } \\
\text { Electioneering } \\
\text { and Finance; } \\
\text { Franchise and } \\
\text { Registration; } \\
\text { Maori; } \\
\text { Method of } \\
\text { Voting; } \\
\text { MP } \\
\text { Qualification }\end{array}$ & Major & High & Yes & Opposed $^{380}$ & Electoral Act & Yes & Yes \\
\hline
\end{tabular}

\footnotetext{
377 Prevented a candidate from being nominated under a new name assumed under a deed poll less than six months before nominations closed: a response to the situations of a man attempting to change his name to the name of a Walt Disney character in order to stand for Parliament; another who changed his name to Jesus Christ; and another who attempted to change his name to the exact name of a candidate for Wellington Central in order to stand against him.

${ }^{378}$ Lowered the voting age from 20 to 18 .

${ }^{379}$ The result of the report of the Electoral Law Committee, which had sat for the prior two years. A long, comprehensive act which created a number of controversial changes to the electoral law. Among other things, extended the franchise to prisoners and allowed for variations in the number of Maori seats.

${ }^{380}$ Some clauses altering entrenched provisions defeated by opposition.
} 


\begin{tabular}{|c|c|c|c|c|c|c|c|c|c|c|c|}
\hline Year & Name & $\begin{array}{c}\text { Government } \\
\text { and Prime } \\
\text { Minister }\end{array}$ & Effect & Area & Class & Contention & $\begin{array}{c}\text { Prior } \\
\text { Consultation } \\
\text { Between } \\
\text { Major Parties }\end{array}$ & $\begin{array}{c}\text { Legislative } \\
\text { Outcome }\end{array}$ & $\begin{array}{c}\text { Select } \\
\text { Committee }\end{array}$ & $\begin{array}{l}\text { Amended } \\
\text { Entrenched } \\
\text { Provisions }\end{array}$ & $\begin{array}{c}\text { Repealed } \\
\text { Previous } \\
\text { Amendment }\end{array}$ \\
\hline 1976 & $\begin{array}{c}\text { Electoral } \\
\text { Amendment } \\
\text { Act }^{381}\end{array}$ & $\begin{array}{l}\text { National } \\
\text { Muldoon }\end{array}$ & Amending & Maori & Major & Moderate & No & Opposed & No & No & Yes \\
\hline 1977 & $\begin{array}{c}\text { Electoral } \\
\text { Amendment } \\
\mathrm{Act}^{382}\end{array}$ & $\begin{array}{l}\text { National } \\
\text { Muldoon }\end{array}$ & Amending & $\begin{array}{l}\text { Electioneering } \\
\text { and Finance; } \\
\text { Franchise \& } \\
\text { Registration }\end{array}$ & Major & High & No & Opposed & $\begin{array}{l}\text { Statutes } \\
\text { Revision }\end{array}$ & No & Yes \\
\hline 1979 & $\begin{array}{c}\text { Electoral } \\
\text { Amendment } \\
\text { Act }^{383}\end{array}$ & $\begin{array}{l}\text { National } \\
\text { Muldoon }\end{array}$ & Amending & Administration & Minor & Moderate & Yes & Not Opposed & $\begin{array}{l}\text { Statutes } \\
\text { Revision }\end{array}$ & No & No \\
\hline
\end{tabular}

${ }^{381}$ Returned the Maori seats to the pre-1975 status quo of four seats instead of a variable number based on population and Maori roll calculations.

${ }^{382}$ Repealed a number of provisions contained in the Electoral Amendment Act 1975 including reversing allowing school teachers to remain at work while standing for Parliament; altering the requirement for residency in an electorate from one month back to three months; prisoners again disqualified from voting; reversed the 1975 provision that anybody qualified to vote but who hadn't registered could vote. Election expenses were doubled from $\$ 2000$ (from the 1975 act) to $\$ 4000$; reversed the clause proscribing the use of loudspeakers, thus returning control to local authorities. Introduced a new provision regulating candidate advertisements.

${ }^{383}$ Attempted to provide a temporary solution to the chaotic situation that had occurred with electoral rolls at the 1978 general election. Passed urgently in light of the upcoming by-election caused by the death of Christchurch Central MP, Bruce Barclay. 


\begin{tabular}{|c|c|c|c|c|c|c|c|c|c|c|c|}
\hline Year & Name & $\begin{array}{c}\text { Government } \\
\text { and Prime } \\
\text { Minister }\end{array}$ & Effect & Area & Class & Contention & $\begin{array}{c}\text { Prior } \\
\text { Consultation } \\
\text { Between } \\
\text { Major Parties }\end{array}$ & $\begin{array}{c}\text { Legislative } \\
\text { Outcome }\end{array}$ & $\begin{array}{c}\text { Select } \\
\text { Committee }\end{array}$ & $\begin{array}{l}\text { Amended } \\
\text { Entrenched } \\
\text { Provisions }\end{array}$ & $\begin{array}{c}\text { Repealed } \\
\text { Previous } \\
\text { Amendment }\end{array}$ \\
\hline 1980 & $\begin{array}{c}\text { Electoral } \\
\text { Amendment } \\
\mathrm{Act}^{384}\end{array}$ & $\begin{array}{l}\text { National } \\
\text { Muldoon }\end{array}$ & Amending & $\begin{array}{l}\text { Administration; } \\
\text { Franchise \& } \\
\text { Registration; } \\
\text { Maori; } \\
\text { Method of } \\
\text { Voting }\end{array}$ & Major & Moderate & Yes & Not Opposed & $\begin{array}{l}\text { Electoral } \\
\text { Law }\end{array}$ & Yes & $\begin{array}{c}\text { Yes } \\
(1975,1977)\end{array}$ \\
\hline 1981 & $\begin{array}{l}\text { Electoral } \\
\text { Amendment } \\
\mathrm{Act}^{385}\end{array}$ & $\begin{array}{l}\text { National } \\
\text { Muldoon }\end{array}$ & Amending & $\begin{array}{l}\text { Administration; } \\
\text { Boundaries; } \\
\text { Electioneering } \\
\text { and Finance; } \\
\text { Maori; } \\
\text { MP } \\
\text { Qualification }\end{array}$ & Minor & Low & Yes & Not Opposed & $\begin{array}{l}\text { Electoral } \\
\text { Law }\end{array}$ & Yes & No \\
\hline 1983 & $\begin{array}{c}\text { Electoral } \\
\text { Amendment } \\
\text { Act }^{386}\end{array}$ & $\begin{array}{l}\text { National } \\
\text { Muldoon }\end{array}$ & Amending & Administration & Minor & Low & Yes & Not Opposed & $\begin{array}{l}\text { Electoral } \\
\text { Law }\end{array}$ & No & No \\
\hline 1985 & $\begin{array}{c}\text { Electoral } \\
\text { Amendment } \\
\mathrm{Act}^{387}\end{array}$ & $\begin{array}{l}\text { Labour } \\
\text { Lange }\end{array}$ & Amending & $\begin{array}{l}\text { Administration; } \\
\text { Maori }\end{array}$ & Minor & Low & Yes & Not Opposed & $\begin{array}{l}\text { Electoral } \\
\text { Law }\end{array}$ & No & $\begin{array}{c}\text { Yes } \\
(1983)\end{array}$ \\
\hline
\end{tabular}

384 A comprehensive set of amendments to a large number of areas of electoral law. Removed party designations from the ballot paper; extended the vote to permanent residents; delayed the exercise of the Maori roll option to a year after a general election, among other things.

${ }^{385}$ Made a wide range of mostly uncontroversial changes to election administration, recommended by the second report of the Electoral Law Committee.

${ }^{386}$ Primarily a technical bill. Non-controversial; implemented the recommendations contained in the third report of the Electoral Law Committee. 


\begin{tabular}{|c|c|c|c|c|c|c|c|c|c|c|c|}
\hline Year & Name & $\begin{array}{c}\text { Government } \\
\text { and Prime } \\
\text { Minister }\end{array}$ & Effect & Area & Class & Contention & \begin{tabular}{|c|} 
Prior \\
Consultation \\
Between \\
Major Parties
\end{tabular} & $\begin{array}{c}\text { Legislative } \\
\text { Outcome }\end{array}$ & $\begin{array}{c}\text { Select } \\
\text { Committee }\end{array}$ & $\begin{array}{l}\text { Amended } \\
\text { Entrenched } \\
\text { Provisions }\end{array}$ & $\begin{array}{c}\text { Repealed } \\
\text { Previous } \\
\text { Amendment }\end{array}$ \\
\hline 1985 & $\begin{array}{c}\text { Electoral } \\
\text { Amendment } \\
\text { (No 2) } \mathrm{Act}^{388}\end{array}$ & $\begin{array}{l}\text { Labour } \\
\text { Lange }\end{array}$ & Amending & $\begin{array}{l}\text { Administration; } \\
\text { Franchise \& } \\
\text { Registration }\end{array}$ & Major & High & No & Opposed & $\begin{array}{l}\text { Electoral } \\
\text { Law }\end{array}$ & No & Yes \\
\hline 1986 & $\begin{array}{c}\text { Electoral } \\
\text { Amendment } \\
\mathrm{Act}^{389}\end{array}$ & $\begin{array}{l}\text { Labour } \\
\text { Lange }\end{array}$ & Amending & Maori & Incidental & None & No & Not Opposed & $\begin{array}{c}\text { Justice \& } \\
\text { Law Reform }\end{array}$ & No & $\begin{array}{l}\text { Yes } \\
(1981)\end{array}$ \\
\hline 1986 & $\begin{array}{c}\text { Electoral } \\
\text { Amendment } \\
\text { Act (No 2) }\end{array}$ & $\begin{array}{l}\text { Labour } \\
\text { Lange }\end{array}$ & Amending & Constitution & Major & None & No & Not Opposed & $\begin{array}{c}\text { Justice \& } \\
\text { Law Reform }\end{array}$ & Yes & Yes \\
\hline 1987 & $\begin{array}{c}\text { Electoral } \\
\text { Amendment } \\
\text { Act }(\text { No } 2)^{391}\end{array}$ & $\begin{array}{l}\text { Labour } \\
\text { Lange }\end{array}$ & Amending & By-election & Minor & Moderate & No & Not Opposed & $\begin{array}{c}\text { Electoral } \\
\text { Law }\end{array}$ & No & No \\
\hline
\end{tabular}

\footnotetext{
${ }^{387}$ Primarily a technical bill; all its substantive measures were the result of the unanimous recommendations of the Electoral Law Committee to remedy "certain problems" encountered during the 1984 General Election. Also altered National's 1983 Electoral Amendment Act and provided that the Maori option would be carried out concurrently with the general re-enrolment.

${ }^{388}$ Reversed the time requirement for residing in an electorate before registration as a voter from three months back to one month; made the dormant file publicly available and authorised its updating.

${ }^{389}$ Provided that Maori electoral boundaries would be promulgated at the same time as general electoral boundaries. Split from larger Law Reform Bill.

${ }^{390}$ Originally part of the Constitution Bill 1986, which clarified and codified existing convention. Clarified the rules relating to transfer of power after an election in the light of the constitutional issues raised when Muldoon left office in 1984.

${ }^{391}$ Prevented any seat which became empty before the general election to be filled before the general election in a by-election. Note that the Electoral Amendment Act 1987 is not listed as it applied to local Government alone.
} 


\begin{tabular}{|c|c|c|c|c|c|c|c|c|c|c|c|}
\hline Year & Name & $\begin{array}{c}\text { Government } \\
\text { and Prime } \\
\text { Minister }\end{array}$ & Effect & Area & Class & Contention & $\begin{array}{c}\text { Prior } \\
\text { Consultation } \\
\text { Between } \\
\text { Major Parties }\end{array}$ & $\begin{array}{c}\text { Legislative } \\
\text { Outcome }\end{array}$ & $\begin{array}{c}\text { Select } \\
\text { Committee }\end{array}$ & $\begin{array}{l}\text { Amended } \\
\text { Entrenched } \\
\text { Provisions }\end{array}$ & $\begin{array}{c}\text { Repealed } \\
\text { Previous } \\
\text { Amendment }\end{array}$ \\
\hline 1989 & $\begin{array}{l}\text { Broadcasting } \\
\mathrm{Act}^{392}\end{array}$ & $\begin{array}{l}\text { Labour } \\
\text { Lange }\end{array}$ & $\begin{array}{l}\text { Original; } \\
\text { Amending }\end{array}$ & $\begin{array}{l}\text { Broadcasting; } \\
\text { Electioneering } \\
\text { \& Finance }\end{array}$ & Major & Moderate & No & Not Opposed & $\begin{array}{c}\text { Planning \& } \\
\text { Development }\end{array}$ & No & No \\
\hline 1989 & $\begin{array}{c}\text { Electoral } \\
\text { Amendment } \\
\mathrm{Act}^{393}\end{array}$ & $\begin{array}{l}\text { Labour } \\
\text { Lange }\end{array}$ & Amending & $\begin{array}{l}\text { Franchise and } \\
\text { Registration }\end{array}$ & Major & High & No & Opposed & No & No & No \\
\hline \multirow[t]{2}{*}{1990} & $\begin{array}{c}\text { Electoral } \\
\text { Amendment } \\
\mathrm{Act}^{394}\end{array}$ & \multirow[t]{2}{*}{$\begin{array}{l}\text { Labour } \\
\text { Palmer }\end{array}$} & \multirow[t]{2}{*}{ Amending } & $\begin{array}{l}\text { Administration; } \\
\text { Electioneering } \\
\text { and Finance; } \\
\text { Franchise and } \\
\text { Registration; } \\
\text { Maori; } \\
\text { Method of } \\
\text { Voting; } \\
\text { MP } \\
\text { Qualification; }\end{array}$ & \multirow[t]{2}{*}{ Major } & \multirow[t]{2}{*}{ Moderate } & \multirow[t]{2}{*}{ Yes } & \multirow[t]{2}{*}{ Not Opposed } & \multirow[t]{2}{*}{$\begin{array}{l}\text { Electoral } \\
\text { Law }\end{array}$} & \multirow[t]{2}{*}{ Yes } & \multirow[t]{2}{*}{ No } \\
\hline & $\begin{array}{c}\text { Broadcasting } \\
\text { Amendment } \\
\mathrm{Act}^{395}\end{array}$ & & & Broadcasting & & & & & & & \\
\hline
\end{tabular}

392 Empowered the Parliamentary Service Commission to allocate 6 hours of appropriated TV and radio advertising among parties.

${ }^{393}$ Overturned Wairarapa decision on section 37 of the Electoral Act 1956, which dealt with the rules for determining a place of residence within New Zealand.

${ }^{394}$ Made technical amendments to the Electoral Act 1956 relating to roll revision. Updated penalties. Altered the calculation to determine number of Maori seats; altered the ballot paper to voting with a tick (an entrenched provision); election expenses raised to $\$ 10,000$. Split from the Electoral Reform Bill on its third reading. 


\begin{tabular}{|c|c|c|c|c|c|c|c|c|c|c|c|}
\hline Year & Name & $\begin{array}{c}\text { Government } \\
\text { and Prime } \\
\text { Minister }\end{array}$ & Effect & Area & Class & Contention & \begin{tabular}{|c|} 
Prior \\
Consultation \\
Between \\
Major Parties
\end{tabular} & $\begin{array}{c}\text { Legislative } \\
\text { Outcome }\end{array}$ & $\begin{array}{c}\text { Select } \\
\text { Committee }\end{array}$ & $\begin{array}{l}\text { Amended } \\
\text { Entrenched } \\
\text { Provisions }\end{array}$ & $\begin{array}{c}\text { Repealed } \\
\text { Previous } \\
\text { Amendment }\end{array}$ \\
\hline & $\begin{array}{c}\text { Term Poll } \\
\text { Act }^{396}\end{array}$ & & Original & Referendum & & & & & & & \\
\hline 1990 & $\begin{array}{l}\text { Broadcasting } \\
\text { and } \\
\text { Radiocomm- } \\
\text { unications } \\
\text { Reform Act }^{397}\end{array}$ & $\begin{array}{l}\text { Labour } \\
\text { Palmer }\end{array}$ & Amending & Broadcasting & Minor & High & No & Opposed & $\begin{array}{l}\text { Planning and } \\
\text { Development }\end{array}$ & No & Yes (1990) \\
\hline 1991 & $\begin{array}{c}\text { Electoral } \\
\text { Amendment } \\
\mathrm{Act}^{398}\end{array}$ & $\begin{array}{l}\text { National } \\
\text { Bolger }\end{array}$ & Amending & Boundaries & Minor & None & Yes & Unanimous & $\begin{array}{l}\text { Electoral } \\
\text { Law }\end{array}$ & Yes & No \\
\hline 1991 & $\begin{array}{c}\text { Electoral } \\
\text { Referendum } \\
\text { Act }^{399}\end{array}$ & $\begin{array}{c}\text { National } \\
\text { Bolger }\end{array}$ & Original & Referendum & Major & Low & Yes & Unanimous & $\begin{array}{l}\text { Electoral } \\
\text { Law }\end{array}$ & No & No \\
\hline
\end{tabular}

395 Appropriated private commercial radio airtime for political party broadcasts. Split from the Electoral Reform Bill on its third reading.

${ }^{396}$ Allowed for a referendum on the parliamentary term. Split from the Electoral Reform Bill on its third reading.

${ }^{397}$ Established a new system and procedures for the handling of parliamentary election broadcasting, after feedback from broadcasters and the public suggested the alterations made by the Electoral Reform Act 1990 had been unsatisfactory and required modification. Note this act was split on the third reading and passed as the Broadcasting Amendment Act (No 2) 1990 and the Radiocommunications Amendment Act (No 2) 1990.

${ }^{398}$ Made minor and non-controversial changes to the make-up of the Representation Commission, as recommended by the report of the Select Committee on Electoral Law on the 1987 General Election.

${ }^{399}$ The Act that set off the process that led to New Zealand's eventual move to MMP. Note the Act was introduced as the Electoral Poll Bill. 


\begin{tabular}{|c|c|c|c|c|c|c|c|c|c|c|c|}
\hline Year & Name & $\begin{array}{c}\text { Government } \\
\text { and Prime } \\
\text { Minister }\end{array}$ & Effect & Area & Class & Contention & \begin{tabular}{|c|} 
Prior \\
Consultation \\
Between \\
Major Parties
\end{tabular} & $\begin{array}{c}\text { Legislative } \\
\text { Outcome }\end{array}$ & $\begin{array}{c}\text { Select } \\
\text { Committee }\end{array}$ & $\begin{array}{l}\text { Amended } \\
\text { Entrenched } \\
\text { Provisions }\end{array}$ & $\begin{array}{c}\text { Repealed } \\
\text { Previous } \\
\text { Amendment }\end{array}$ \\
\hline 1992 & $\begin{array}{c}\text { Electoral } \\
\text { Amendment } \\
\text { Act }^{400}\end{array}$ & $\begin{array}{l}\text { National } \\
\text { Bolger }\end{array}$ & Amending & Technical & Minor & Low & No & Not Opposed & $\begin{array}{l}\text { Electoral } \\
\text { Law }\end{array}$ & No & No \\
\hline 1993 & $\begin{array}{l}\text { Electoral } \\
\text { Act }^{401}\end{array}$ & $\begin{array}{l}\text { National } \\
\text { Bolger }\end{array}$ & $\begin{array}{c}\text { Original; } \\
\text { Amending; } \\
\text { Amalgamating }\end{array}$ & $\begin{array}{l}\text { Administration; } \\
\text { Boundaries; } \\
\text { Constitution; } \\
\text { Electioneering } \\
\text { and Finance; } \\
\text { Electoral } \\
\text { System; } \\
\text { Franchise and } \\
\text { Registration; } \\
\text { Maori; } \\
\text { Method of } \\
\text { Voting; } \\
\text { MP } \\
\text { Qualification }\end{array}$ & Milestone & High & Yes & $\begin{array}{c}\text { Not } \\
\text { Opposed }^{402}\end{array}$ & $\begin{array}{l}\text { Electoral } \\
\text { Law }\end{array}$ & Yes & Yes \\
\hline
\end{tabular}

${ }^{400}$ Rectified a legal problem in the Representation Commission's work after it was found the figures contained in the report of the Government Statistician to the commission in order to calculate the Maori seats had not been calculated in accordance with the law.

${ }^{401}$ The comprehensive act governing elections in New Zealand. Replaced the Electoral Act 1956. The Senate Bill, separated from the Electoral Bill in the committee stages, was intended for introduction should the referendum on the electoral system result in the retention of FFP. It did not, and the Senate Bill lapsed.

${ }^{402}$ Numerous divisions were held during the committee stages on various parts. These were conscience votes. Passed third reading without division. 


\begin{tabular}{|c|c|c|c|c|c|c|c|c|c|c|c|}
\hline Year & Name & $\begin{array}{c}\text { Government } \\
\text { and Prime } \\
\text { Minister }\end{array}$ & Effect & Area & Class & Contention & $\begin{array}{c}\text { Prior } \\
\text { Consultation } \\
\text { Between } \\
\text { Major Parties }\end{array}$ & $\begin{array}{l}\text { Legislative } \\
\text { Outcome }\end{array}$ & $\begin{array}{c}\text { Select } \\
\text { Committee }\end{array}$ & $\begin{array}{l}\text { Amended } \\
\text { Entrenched } \\
\text { Provisions }\end{array}$ & $\begin{array}{c}\text { Repealed } \\
\text { Previous } \\
\text { Amendment }\end{array}$ \\
\hline 1993 & $\begin{array}{c}\text { Electoral } \\
\text { Referendum } \\
\mathrm{Act}^{403}\end{array}$ & $\begin{array}{l}\text { National } \\
\text { Bolger }\end{array}$ & Original & Referendum & Major & Moderate & Yes & $\begin{array}{c}\text { Not } \\
\text { Opposed }^{404}\end{array}$ & $\begin{array}{l}\text { Electoral } \\
\text { Law }\end{array}$ & No & No \\
\hline 1993 & $\begin{array}{c}\text { Electoral } \\
\text { Amendment } \\
\text { Act }^{405}\end{array}$ & $\begin{array}{l}\text { National } \\
\text { Bolger }\end{array}$ & Amending & $\begin{array}{l}\text { Franchise and } \\
\text { Registration }\end{array}$ & Major & High & No & Opposed & $\begin{array}{l}\text { Electoral } \\
\text { Law }\end{array}$ & No & Yes \\
\hline 1995 & $\begin{array}{c}\text { Electoral } \\
\text { Amendment } \\
\text { Act }^{406}\end{array}$ & $\begin{array}{l}\text { National } \\
\text { Bolger }\end{array}$ & Amending & Technical & Minor & None & Yes & Unanimous & $\begin{array}{l}\text { Electoral } \\
\text { Law }\end{array}$ & No & No \\
\hline 1995 & $\begin{array}{c}\text { Electoral } \\
\text { Amendment } \\
\text { Act }(\text { No } 2)^{407}\end{array}$ & $\begin{array}{l}\text { National } \\
\text { Bolger }\end{array}$ & Amending & $\begin{array}{l}\text { Administration; } \\
\text { Electioneering } \\
\text { and Finance; } \\
\text { Method of } \\
\text { Voting }\end{array}$ & Major & Moderate & Yes & $\begin{array}{l}\text { No Multi- } \\
\text { partisan } \\
\text { Support }\end{array}$ & $\begin{array}{l}\text { Electoral } \\
\text { Law }\end{array}$ & No & No \\
\hline
\end{tabular}

\footnotetext{
${ }^{403}$ Provided the legislative basis for the second referendum on the electoral system

${ }^{404}$ Numerous divisions were held during the committee stages on various parts. These were conscience votes. Passed third reading without division.

${ }^{405}$ Closed the electoral rolls on Writ Day, as recommended by the Electoral Law Committee in its report on the 1990 General Election.

${ }^{406}$ Part of Electoral Reform Bill 1995. Clarified any ambiguity there might be that the amendments to the entrenched provisions in section 168 of the Electoral Act could be passed only by members elected under the 1993 Act.

${ }^{407}$ The Government and Opposition voted to alter the form of the ballot paper, to the objection of Parliament's minor parties. Made changes in four significant areas, as well as other minor changes. Implemented a disclosure regime and a limit on the amount that parties may spend on political campaigns.

${ }^{408}$ Government and Opposition unanimous. For: National, Labour, Christian Democrats; Against: United, NZ First, Alliance, NZ Conservative
} 


\begin{tabular}{|c|c|c|c|c|c|c|c|c|c|c|c|}
\hline Year & Name & $\begin{array}{c}\text { Government } \\
\text { and Prime } \\
\text { Minister }\end{array}$ & Effect & Area & Class & Contention & \begin{tabular}{|c|} 
Prior \\
Consultation \\
Between \\
Major Parties
\end{tabular} & $\begin{array}{c}\text { Legislative } \\
\text { Outcome }\end{array}$ & $\begin{array}{c}\text { Select } \\
\text { Committee }\end{array}$ & $\begin{array}{l}\text { Amended } \\
\text { Entrenched } \\
\text { Provisions }\end{array}$ & $\begin{array}{c}\text { Repealed } \\
\text { Previous } \\
\text { Amendment }\end{array}$ \\
\hline 1996 & $\begin{array}{c}\text { Electoral } \\
\text { Amendment } \\
\mathrm{Act}^{409}\end{array}$ & $\begin{array}{l}\text { National } \\
\text { Bolger }\end{array}$ & Amending & Technical & Incidental & None & No & Unanimous & $\begin{array}{l}\text { Electoral } \\
\text { Law }\end{array}$ & No & Yes \\
\hline \multirow{2}{*}{1996} & $\begin{array}{c}\text { Broadcasting } \\
\text { Amendment } \\
\mathrm{Act}^{410}\end{array}$ & \multirow{2}{*}{$\begin{array}{l}\text { National } \\
\text { Bolger }\end{array}$} & \multirow{2}{*}{ Amending } & \multirow{2}{*}{$\begin{array}{l}\text { Broadcasting; } \\
\text { Electioneering } \\
\text { and Finance }\end{array}$} & \multirow{2}{*}{ Minor } & \multirow{2}{*}{ Low } & \multirow{2}{*}{ No } & \multirow{2}{*}{$\begin{array}{l}\text { No Multi- } \\
\text { partisan } \\
\text { Support }^{411}\end{array}$} & \multirow{2}{*}{$\begin{array}{l}\text { Finance and } \\
\text { Expenditure }\end{array}$} & \multirow{2}{*}{ No } & \multirow{2}{*}{ Yes } \\
\hline & $\begin{array}{c}\text { Electoral } \\
\text { Amendment } \\
\text { Act }(\text { No } 2)^{412}\end{array}$ & & & & & & & & & & \\
\hline 1996 & $\begin{array}{c}\text { Electoral } \\
\text { Amendment } \\
\text { Act }(\text { No 3) }\end{array}$ & $\begin{array}{l}\text { National } \\
\text { Bolger }\end{array}$ & Amending & $\begin{array}{l}\text { Franchise and } \\
\text { Registration; } \\
\text { Maori }\end{array}$ & Incidental & None & No & Not Opposed & $\begin{array}{c}\text { Justice \& } \\
\text { Law Reform }\end{array}$ & No & No \\
\hline
\end{tabular}

${ }^{409}$ Amended a printing error that occurred in the preparation of the Electoral Amendment Act (No 2) 1995 for Assent. Changed the national donation figure from $\$ 1000$ to $\$ 10000$.

${ }^{410}$ Further amended the Electoral Act 1993, in the light of the Electoral Amendment Act (No 2) 1995, to allow the Government and Opposition to each nominate a person to serve on the Electoral Commission for the purposes of its jurisdiction under the Broadcasting Act 1989. Made other minor changes to funding and broadcasting spending limits. Introduced as Broadcasting Amendment Bill, split into Broadcasting Amendment Bill and Electoral Amendment Bill (No 4) before third reading

${ }^{411}$ Government and Opposition unanimous. For: National, Labour, Christian Democrats; Against: United, NZ First, Alliance, NZ Conservative

${ }^{412}$ Split from the Broadcasting Bill 1996 on its third reading.

${ }^{413}$ Amended s 77(2) of the Electoral Act 1993 to alter the period in which Maori could switch electoral rolls from two months to four months. 


\begin{tabular}{|c|c|c|c|c|c|c|c|c|c|c|c|}
\hline Year & Name & $\begin{array}{c}\text { Government } \\
\text { and Prime } \\
\text { Minister }\end{array}$ & Effect & Area & Class & Contention & $\begin{array}{c}\text { Prior } \\
\text { Consultation } \\
\text { Between } \\
\text { Major Parties }\end{array}$ & $\begin{array}{l}\text { Legislative } \\
\text { Outcome }\end{array}$ & $\begin{array}{c}\text { Select } \\
\text { Committee }\end{array}$ & $\begin{array}{l}\text { Amended } \\
\text { Entrenched } \\
\text { Provisions }\end{array}$ & $\begin{array}{c}\text { Repealed } \\
\text { Previous } \\
\text { Amendment }\end{array}$ \\
\hline 2001 & $\begin{array}{c}\text { Electoral } \\
\text { (Integrity) } \\
\text { Amendment } \\
\text { Act }^{414}\end{array}$ & $\begin{array}{l}\text { Labour } \\
\text { Clark }\end{array}$ & Amending & $\begin{array}{c}\text { MP } \\
\text { Qualification }\end{array}$ & Major & Moderate & No & Opposed $^{415}$ & $\begin{array}{l}\text { Justice \& } \\
\text { Electoral }\end{array}$ & No & No \\
\hline 2002 & $\begin{array}{c}\text { Electoral } \\
\text { Amendment } \\
\text { Act }^{416}\end{array}$ & $\begin{array}{l}\text { Labour } \\
\text { Clark }\end{array}$ & Amending & $\begin{array}{l}\text { Administration; } \\
\text { Electioneering } \\
\text { and Finance; } \\
\text { Franchise and } \\
\text { Registration; } \\
\text { Maori }\end{array}$ & Minor & High & No & Opposed $^{417}$ & $\begin{array}{l}\text { Justice \& } \\
\text { Electoral }\end{array}$ & No & No \\
\hline 2003 & $\begin{array}{c}\text { Electoral } \\
\text { (Vacancies) } \\
\text { Amendment } \\
\text { Act }^{418}\end{array}$ & $\begin{array}{l}\text { Labour } \\
\text { Clark }\end{array}$ & Amending & $\begin{array}{c}\text { MP } \\
\text { Qualification }\end{array}$ & Minor & High & No & Opposed $^{419}$ & No & No & No \\
\hline
\end{tabular}

${ }^{414}$ Prevented 'party-hopping'.

${ }^{415}$ For: Labour, Alliance, NZ First; Against: National, ACT, Green Party, United

${ }^{416}$ Made mostly uncontroversial administrative amendments to the Electoral Act. Originally attempted to ban the publishing of opinion polls before an election, but this clause was removed in the committee stages. Controversy arose over the Bill's proposal to count the party vote of those who voted in the wrong electorate, the early counting of advance votes and hospital votes, and continuous enrolment.

${ }^{417}$ For: Labour, Alliance, Green Party; Against: National, ACT, NZ First, United

${ }^{418}$ Amended the Electoral Act 1993 to save Hon Harry Duynhoven, MP for New Plymouth, from disqualification as an MP for applying for Dutch citizenship. Split from the Electoral Matters Bill 2004 on its third reading.

${ }^{419}$ For: Labour, Green Party, Progressive; Against: National, ACT, NZ First, United; Abstention: Hunt (Speaker) 


\begin{tabular}{|c|c|c|c|c|c|c|c|c|c|c|c|}
\hline Year & Name & $\begin{array}{c}\text { Government } \\
\text { and Prime } \\
\text { Minister }\end{array}$ & Effect & Area & Class & Contention & $\begin{array}{c}\text { Prior } \\
\text { Consultation } \\
\text { Between } \\
\text { Major Parties }\end{array}$ & $\begin{array}{c}\text { Legislative } \\
\text { Outcome }\end{array}$ & $\begin{array}{c}\text { Select } \\
\text { Committee }\end{array}$ & $\begin{array}{l}\text { Amended } \\
\text { Entrenched } \\
\text { Provisions }\end{array}$ & $\begin{array}{c}\text { Repealed } \\
\text { Previous } \\
\text { Amendment }\end{array}$ \\
\hline 2004 & $\begin{array}{l}\text { Electoral } \\
\text { Amendment } \\
\text { Act }^{420}\end{array}$ & $\begin{array}{l}\text { Labour } \\
\text { Clark }\end{array}$ & Amending & $\begin{array}{c}\text { Administration; } \\
\text { MP } \\
\text { Qualification }\end{array}$ & Minor & Low & No & Not Opposed & $\begin{array}{l}\text { Justice \& } \\
\text { Electoral }\end{array}$ & No & No \\
\hline 2004 & $\begin{array}{c}\text { Broadcasting } \\
\text { Amendment } \\
\text { Act }^{421}\end{array}$ & $\begin{array}{l}\text { Labour } \\
\text { Clark }\end{array}$ & Amending & Broadcasting & Minor & Low & No & Not Opposed & $\begin{array}{l}\text { Justice \& } \\
\text { Electoral }\end{array}$ & No & No \\
\hline 2005 & $\begin{array}{c}\text { Electoral } \\
\text { Amendment } \\
\text { Act }^{422}\end{array}$ & $\begin{array}{l}\text { Labour } \\
\text { Clark }\end{array}$ & Amending & Administration & Incidental & None & No & Not Opposed & $\begin{array}{c}\text { Government } \\
\text { Administration }\end{array}$ & No & No \\
\hline \multirow[t]{2}{*}{2007} & $\begin{array}{c}\text { Electoral } \\
\text { Finance } \mathrm{Act}^{423}\end{array}$ & \multirow[t]{2}{*}{$\begin{array}{l}\text { Labour } \\
\text { Clark }\end{array}$} & \multirow[t]{2}{*}{$\begin{array}{l}\text { Original; } \\
\text { Amending }\end{array}$} & \multirow{2}{*}{$\begin{array}{l}\text { Broadcasting; } \\
\text { Electioneering } \\
\text { and Finance }\end{array}$} & \multirow[t]{2}{*}{ Major } & \multirow[t]{2}{*}{ High } & \multirow[t]{2}{*}{ No } & \multirow[t]{2}{*}{ Opposed $^{424}$} & \multirow[t]{2}{*}{$\begin{array}{l}\text { Justice \& } \\
\text { Electoral }\end{array}$} & \multirow[t]{2}{*}{ No } & \multirow[t]{2}{*}{ No } \\
\hline & $\begin{array}{c}\text { Electoral } \\
\text { Amendment } \\
\text { Act }^{425}\end{array}$ & & & & & & & & & & \\
\hline
\end{tabular}

${ }^{420}$ Further clarified the provisions relating to disqualification of an MP and made other small administrative changes to the Electoral Act 1993.

${ }^{421}$ Made a number of administrative changes to rules surrounding election broadcasting. Repealed the requirement for the Electoral Commission to invite broadcasters to provide free or discounted time for electoral broadcasting. Ensured only registered parties eligible for allocations of time and money. Split from the Electoral Matters Bill 2004 on its third reading.

${ }^{422}$ Made two minor, technical changes to the Electoral Act 1993. Introduced as part of the Statutes Amendment Bill (No 4) 2004

${ }^{423}$ A wide-sweeping act that regulated electioneering and electoral finance, and placed extensive limits on election campaigning.

${ }^{424}$ For: Labour, NZ First, Green Party, Progressive; Against: National, Maori Party, United Future, ACT, Field (Independent).

${ }^{425}$ Split from the Electoral Finance Bill 2007 on its third reading. 


\begin{tabular}{|c|c|c|c|c|c|c|c|c|c|c|c|}
\hline Year & Name & $\begin{array}{l}\text { Government } \\
\text { and Prime } \\
\text { Minister }\end{array}$ & Effect & Area & Class & Contention & $\begin{array}{c}\text { Prior } \\
\text { Consultation } \\
\text { Between } \\
\text { Major Parties }\end{array}$ & $\begin{array}{l}\text { Legislative } \\
\text { Outcome }\end{array}$ & $\begin{array}{c}\text { Select } \\
\text { Committee }\end{array}$ & $\begin{array}{l}\text { Amended } \\
\text { Entrenched } \\
\text { Provisions }\end{array}$ & $\begin{array}{c}\text { Repealed } \\
\text { Previous } \\
\text { Amendment }\end{array}$ \\
\hline & $\begin{array}{c}\text { Broadcasting } \\
\text { Amendment } \\
\text { Act }^{426}\end{array}$ & & & & & & & & & & \\
\hline
\end{tabular}

\footnotetext{
${ }^{426}$ Split from the Electoral Finance Bill 2007 on its third reading.
} 


\section{Appendix B}

\section{Unsuccessful Electoral Reform Bills 1927 - 2007 (in chronological order)}

\begin{tabular}{|c|c|c|c|c|c|c|c|}
\hline Year & Name & Origin & Effect & $\begin{array}{l}\text { Affected Areas of } \\
\text { Electoral Law }\end{array}$ & Contention & Outcome & Select Committee \\
\hline 1929 & Preferential Voting Bill ${ }^{427}$ & $\begin{array}{l}\text { Private Member } \\
J M c C o m b s \\
\text { (Labour) }\end{array}$ & Original & Electoral System & None & $\begin{array}{l}\text { Lapsed after } \\
\text { First Reading }\end{array}$ & No \\
\hline 1931 & Electoral Amendment Bill ${ }^{428}$ & $\begin{array}{l}\text { Private Member } \\
\text { C Clinkard } \\
\text { (Coalition) }\end{array}$ & Amending & Electoral System & None & $\begin{array}{l}\text { Lapsed after } \\
\text { First Reading }\end{array}$ & No \\
\hline 1932 & Electoral Amendment Bill ${ }^{429}$ & $\begin{array}{l}\text { Government } \\
\text { G Forbes } \\
\text { (Coalition) }\end{array}$ & Amending & Term Length & None & $\begin{array}{l}\text { Lapsed after } \\
\text { First Reading }\end{array}$ & No \\
\hline 1932 & Electoral Amendment Bill ${ }^{430}$ & $\begin{array}{c}\text { Private Member } \\
\text { G Black } \\
\text { (Independent) }\end{array}$ & Amending & - & None & $\begin{array}{l}\text { Lapsed after } \\
\text { First Reading }\end{array}$ & No \\
\hline
\end{tabular}

\footnotetext{
${ }^{427}$ Sought to prescribe a basic PR system of voting at national referendum polls.

${ }^{428}$ Sought to introduce a simple version of STV.

${ }^{429}$ Possibly an aborted attempt to extend the life of Parliament by a year. This was done instead in the Finance Act 1932. The bill did not proceed past first reading and was not debated and it has not been possible to obtain details of the contents.

${ }^{430}$ This bill did not proceed past first reading and was not debated. It has not been possible to obtain details of the contents
} 


\begin{tabular}{|c|c|c|c|c|c|c|c|}
\hline Year & Name & Origin & Effect & $\begin{array}{l}\text { Affected Areas of } \\
\text { Electoral Law }\end{array}$ & Contention & Outcome & Select Committee \\
\hline 1932 & Electoral Amendment Bill (No 2) & $\begin{array}{c}\text { Private Member } \\
\text { C Chapman } \\
\text { (Labour) }\end{array}$ & Amending & - & None & $\begin{array}{l}\text { Lapsed after } \\
\text { First Reading }\end{array}$ & No \\
\hline 1933 & Electoral Amendment Bill ${ }^{432}$ & $\begin{array}{c}\text { Private Member } \\
\text { E Tirikatene } \\
\text { (Ratana) }\end{array}$ & Amending & Maori & Low & $\begin{array}{l}\text { Lapsed after } \\
\text { First Reading }\end{array}$ & No \\
\hline 1934 & $\begin{array}{c}\text { Electoral Amendment (Date of General } \\
\text { Election) Bill }{ }^{433}\end{array}$ & $\begin{array}{c}\text { Private Member } \\
\text { M.J. Savage } \\
\text { (Labour) }\end{array}$ & Amending & Term Length & High & $\begin{array}{c}\text { Ruled as involving } \\
\text { an Appropriation; } \\
\text { Defeated on Second } \\
\text { Reading }\end{array}$ & No \\
\hline 1934 & Electoral Amendment Bill ${ }^{434}$ & $\begin{array}{l}\text { Private Member } \\
\text { C Clinkard } \\
\text { (Coalition) }\end{array}$ & Amending & Electoral System & Low & $\begin{array}{l}\text { Lapsed after } \\
\text { First Reading }\end{array}$ & No \\
\hline 1965 & Electoral Amendment Bill (No 2) & $\begin{array}{c}\text { Private Member } \\
R \text { Mason } \\
\text { (Labour) }\end{array}$ & Amending & $\begin{array}{l}\text { Electioneering and } \\
\text { Finance }\end{array}$ & Moderate & $\begin{array}{c}\text { Defeated on Second } \\
\text { Reading }\end{array}$ & No \\
\hline
\end{tabular}

\footnotetext{
${ }_{431}$ This bill did not proceed past first reading and was not debated. It has not been possible to obtain details of the contents.

${ }^{432}$ Sought to make the Maori ballot a secret ballot. Unlike the European ballot, the Maori ballot was carried out by declaration.

${ }^{433}$ Sought to bring the current Parliament (extended by the Coalition to four years) to an end after the former three years.

${ }^{434}$ Again sought to introduce a simple version of STV.

${ }^{435}$ Sought, in the face of increasing use of television and other media for electioneering, to promote the 'corner meeting' style of campaigning by allowing meetings to be held "without reference to bylaws".
} 


\begin{tabular}{|c|c|c|c|c|c|c|c|}
\hline Year & Name & Origin & Effect & $\begin{array}{l}\text { Affected Areas of } \\
\text { Electoral Law }\end{array}$ & Contention & Outcome & Select Committee \\
\hline 1966 & Electoral Amendment Bill ${ }^{436}$ & $\begin{array}{l}\text { Government } \\
\text { K Holyoake } \\
\text { (National) }\end{array}$ & Amending & $\begin{array}{l}\text { Franchise and } \\
\text { Registration }\end{array}$ & Low & $\begin{array}{l}\text { Lapsed after } \\
\text { First Reading }\end{array}$ & Statutes Revision \\
\hline 1972 & Electoral Amendment Bill ${ }^{437}$ & $\begin{array}{c}\text { Private Member } \\
\text { C Moyle } \\
\text { (Labour) }\end{array}$ & Amending & $\begin{array}{l}\text { Franchise and } \\
\text { Registration }\end{array}$ & Moderate & $\begin{array}{c}\text { Ruled as involving } \\
\text { an Appropriation; } \\
\text { Lapsed after } \\
\text { First Reading }\end{array}$ & No \\
\hline 1976 & Electoral Amendment Bill ${ }^{438}$ & $\begin{array}{c}\text { Private Member } \\
\text { J Hunt } \\
\text { (Labour) }\end{array}$ & Amending & $\begin{array}{l}\text { Administration; } \\
\text { Constitution }\end{array}$ & Moderate & $\begin{array}{c}\text { Ruled as involving } \\
\text { an Appropriation; } \\
\text { Lapsed after Second } \\
\text { Reading }\end{array}$ & No \\
\hline 1978 & Electoral Amendment Bill ${ }^{439}$ & $\begin{array}{c}\text { Private Member } \\
\text { B Beetham } \\
\text { (Social Credit) }\end{array}$ & Amending & Boundaries & Moderate & $\begin{array}{c}\text { Ruled as involving } \\
\text { an Appropriation; } \\
\text { Lapsed after Second } \\
\text { Reading }\end{array}$ & No \\
\hline
\end{tabular}

\footnotetext{
${ }^{436}$ Proposed that "servicemen who are under 21 years of age will be qualified to vote at a general election if they are serving overseas in a special area as members of the naval, military or air forces, and provision is made for this special service area to be declared by Order in Council. It will be an area where there is an imminent threat of war or danger or disturbance at the risk of life."

${ }^{437}$ Sought to lower the voting age to 18 years and allow the Chief Electoral Officer to actively enrol people to vote.

${ }^{438}$ Proposed lengthening the sessions of Parliament by requiring it to sit no later than 90 days after the return of the writs following an election. Attempted to even out the House's sitting schedule to make it sit 90 days a year (3 days every 3 weeks of every month). The other provisions extinguished the Governor-General's powers to prorogue or dissolve Parliament without an absolute majority of the House - no doubt a reaction to Sir John Kerr's actions in Australia.

${ }^{439}$ Sought to alter the Electoral Commission to include, alongside Government and Opposition representatives, representatives from the Social Credit Political League and the Values Party.
} 


\begin{tabular}{|c|c|c|c|c|c|c|c|}
\hline Year & Name & Origin & Effect & $\begin{array}{c}\text { Affected Areas of } \\
\text { Electoral Law }\end{array}$ & Contention & Outcome & Select Committee \\
\hline 1978 & Electoral Amendment Bill (No 2) & $\begin{array}{l}\text { Private Member } \\
\text { Connelly } \\
\text { (Labour) }\end{array}$ & Amending & $\begin{array}{l}\text { Administration; } \\
\text { Franchise and } \\
\text { Registration }\end{array}$ & Moderate & $\begin{array}{c}\text { Ruled as involving } \\
\text { an Appropriation; } \\
\text { Lapsed after Second } \\
\text { Reading }\end{array}$ & No \\
\hline 1978 & Elections and Polls Bill ${ }^{441}$ & $\begin{array}{l}\text { Private Member } \\
\qquad G \text { Wall } \\
\text { (Labour) }\end{array}$ & Amending & $\begin{array}{l}\text { Administration; } \\
\text { Franchise and } \\
\text { Registration }\end{array}$ & High & $\begin{array}{l}\text { Defeated on } \\
\text { Introduction }\end{array}$ & No \\
\hline 1978 & Voting Rights Protection Bill ${ }^{442}$ & $\begin{array}{l}\text { Private Member } \\
\qquad G \text { Wall } \\
\text { (Labour) }\end{array}$ & Amending & $\begin{array}{l}\text { Administration; } \\
\text { Franchise and } \\
\text { Registration }\end{array}$ & High & $\begin{array}{l}\text { Defeated on } \\
\text { Introduction }\end{array}$ & No \\
\hline 1980 & Electoral Amendment Bill ${ }^{443}$ & $\begin{array}{l}\text { Private Member } \\
\qquad G \text { Wall } \\
\text { (Labour) }\end{array}$ & Amending & $\begin{array}{l}\text { Administration; } \\
\text { Franchise and } \\
\text { Registration }\end{array}$ & High & $\begin{array}{l}\text { Defeated on } \\
\text { Introduction }\end{array}$ & No \\
\hline 1980 & Second Ballot Bill ${ }^{444}$ & $\begin{array}{l}\text { Private Member } \\
\qquad \begin{array}{l}\text { Wall } \\
\text { (Labour) }\end{array}\end{array}$ & Amending & Electoral System & Low & $\begin{array}{l}\text { Ruled as involving } \\
\text { an Appropriation; } \\
\text { Defeated on } \\
\text { Introduction }\end{array}$ & No \\
\hline
\end{tabular}

${ }^{440}$ Sought to alter the Electoral Act to attempt to ensure the enrolment of as many electors as possible prior to election day.

${ }^{441}$ Proposed leaving enrolment open up until and during a general election.

${ }^{442}$ Proposed alteration of the Electoral Act 1956 to provide franchise on eligibility to vote rather than being listed on the electoral roll.

${ }^{443}$ Proposed leaving enrolment open up until and during a general election; proposed introduction of an immunity clause to "protect people from... prosecution following their failure... to fulfil their [electoral] obligations under existing legislation."

${ }^{444}$ Proposed that, if an MP failed to be elected by a majority, a second ballot would be held the following Saturday between the top two candidates. 


\begin{tabular}{|c|c|c|c|c|c|c|c|}
\hline Year & Name & Origin & Effect & $\begin{array}{l}\text { Affected Areas of } \\
\text { Electoral Law }\end{array}$ & Contention & Outcome & Select Committee \\
\hline 1986 & Political Advertising Bill ${ }^{445}$ & $\begin{array}{c}\text { Private Member } \\
\text { Cox } \\
\text { (National) }\end{array}$ & Amending & $\begin{array}{c}\text { Broadcasting; } \\
\text { Electioneering and } \\
\text { Finance }\end{array}$ & Moderate & $\begin{array}{l}\text { Defeated on } \\
\text { Introduction }\end{array}$ & No \\
\hline 1986 & $\begin{array}{c}\text { Electoral (Representation Commission) } \\
\text { Amendment Bill }\end{array}$ & $\begin{array}{l}\text { Private Member } \\
\qquad \text { Knapp } \\
\text { (Democrats) }\end{array}$ & Amending & Boundaries & High & $\begin{array}{c}\text { Ruled as involving } \\
\text { an Appropriation; } \\
\text { Defeated on } \\
\text { Introduction }\end{array}$ & No \\
\hline 1988 & $\begin{array}{c}\text { Public Finance (Restraint of Political } \\
\text { Advertising) Bill }\end{array}$ & $\begin{array}{c}\text { Private Member } \\
\text { S Upton } \\
\text { (National) }\end{array}$ & Amending & $\begin{array}{l}\text { Electioneering and } \\
\text { Finance }\end{array}$ & High & $\begin{array}{l}\text { Defeated on } \\
\text { Introduction }\end{array}$ & No \\
\hline 1989 & Electoral Expenses Bill ${ }^{448}$ & $\begin{array}{c}\text { Private Member } \\
\text { C Matthewson } \\
\text { (Labour) }\end{array}$ & Amending & $\begin{array}{l}\text { Electioneering and } \\
\text { Finance }\end{array}$ & High & $\begin{array}{l}\text { Lapsed after referral } \\
\text { to Select Committee }\end{array}$ & Electoral Law \\
\hline 1990 & $\begin{array}{l}\text { Proportional Representation Indicative } \\
\text { Referendum Bill }\end{array}$ & $\begin{array}{l}\text { Private Member } \\
\text { Mr Terris } \\
\text { (Labour) }\end{array}$ & Original & Electoral System & Moderate & $\begin{array}{l}\text { Lapsed after report } \\
\text { of Select Committee }\end{array}$ & Electoral Law \\
\hline
\end{tabular}

\footnotetext{
${ }^{445}$ Proposed extensive limits on expenditure by Government on advertising and restrictions on the types of advertising public money could be used for.

${ }^{446}$ Sought to alter section 15 of the Electoral Act to "allow the participation of all bona fide political parties in the process of setting electoral boundaries."

447 Sought to make Government itemise all money spent on advertising Government policies.

${ }^{448}$ Sought to validate the expenditure of Mr Boorman, who had been removed from Parliament as a result of the Wairarapa electoral petition.

${ }^{449}$ Proposed the holding of two referenda on the voting system: one to determine the question of a change and one to determine the type of change. The Bolger Government introduced similar bills after it came to power, and these led to the introduction of MMP.
} 


\begin{tabular}{|c|c|c|c|c|c|c|c|}
\hline Year & Name & Origin & Effect & $\begin{array}{l}\text { Affected Areas of } \\
\text { Electoral Law }\end{array}$ & Contention & Outcome & Select Committee \\
\hline 1990 & $\begin{array}{l}\text { Mixed Member Proportional } \\
\text { Representation Poll Bill }\end{array}$ & $\begin{array}{c}\text { Private Member } \\
J \text { Anderton } \\
\text { (NewLabour) }\end{array}$ & Original & Electoral System & Moderate & $\begin{array}{l}\text { Defeated on } \\
\text { Introduction }^{451}\end{array}$ & No \\
\hline 1992 & $\begin{array}{c}\text { Mixed Member Proportional } \\
\text { Representation Referendum Bill }^{452}\end{array}$ & $\begin{array}{c}\text { Private Member } \\
\text { J Anderton } \\
\text { (NewLabour) }\end{array}$ & Original & Electoral System & Low & $\begin{array}{l}\text { Lapsed after referral } \\
\text { to Select Committee }\end{array}$ & Electoral Law \\
\hline 1994 & $\begin{array}{l}\text { Electoral Reform (Representation } \\
\text { Commission) Bill }{ }^{453}\end{array}$ & $\begin{array}{c}\text { Private Member } \\
\text { J Anderton } \\
\text { (NewLabour) }\end{array}$ & Amending & Boundaries & Low & $\begin{array}{l}\text { Lapsed after referral } \\
\text { to Select Committee }\end{array}$ & Electoral Law \\
\hline 1995 & Elector Registration Extension Bill ${ }^{454}$ & $\begin{array}{c}\text { Private Member } \\
\text { J Hunt } \\
\text { (Labour) }\end{array}$ & Amending & $\begin{array}{l}\text { Franchise and } \\
\text { Registration }\end{array}$ & Moderate & $\begin{array}{l}\text { Defeated on } \\
\text { Introduction }\end{array}$ & No \\
\hline 1995 & $\begin{array}{l}\text { Disclosure of Political Donations and } \\
\text { Gifts Bill }\end{array}$ & $\begin{array}{c}\text { Private Member } \\
\text { W Peters } \\
\text { (NZ First) }\end{array}$ & Amending & $\begin{array}{l}\text { Electioneering and } \\
\text { Finance }\end{array}$ & Low & $\begin{array}{l}\text { Ruled as involving } \\
\text { an Appropriation; } \\
\text { Ruled out of order } \\
\text { after report of } \\
\text { Select Committee }\end{array}$ & Electoral Law \\
\hline
\end{tabular}

\footnotetext{
${ }^{450}$ Proposed putting MMP straight to a referendum at the 1990 General Election, without an initial indicative referendum.

${ }^{451}$ Conscience Vote.

${ }^{452}$ Proposed the introduction of MMP for the 1993 General Election.

${ }^{453}$ Sought to remove all political representation from the Representation Commission

${ }^{454}$ Sought to extend the latest day on which electors may register from writ day to the day before polling day. This would have restored the position to that which applied before the enactment of the Electoral Act 1993.

${ }^{455}$ Proposed a transparent public register of donations to political parties.
} 


\begin{tabular}{|c|c|c|c|c|c|c|c|}
\hline Year & Name & Origin & Effect & $\begin{array}{l}\text { Affected Areas of } \\
\text { Electoral Law }\end{array}$ & Contention & Outcome & Select Committee \\
\hline 1997 & Electoral (Party Registration) Bill ${ }^{456}$ & $\begin{array}{c}\text { Private Member } \\
M \text { Cullen } \\
\text { (Labour) }\end{array}$ & Amending & MP Qualification & Moderate & $\begin{array}{l}\text { Defeated after } \\
\text { report of Select } \\
\text { Committee }^{457}\end{array}$ & Electoral Law \\
\hline 1998 & Electoral Amendment Bill ${ }^{458}$ & $\begin{array}{l}\text { Government } \\
\text { J Shipley } \\
\text { (National) }\end{array}$ & Amending & Administration & None & $\begin{array}{l}\text { Carried over at end } \\
\text { of session and } \\
\text { incorporated into } \\
2002 \text { Amendment } \\
\text { Act }\end{array}$ & Electoral Law \\
\hline 1999 & $\begin{array}{l}\text { Broadcasting (Election Broadcasting) } \\
\text { Amendment Bill }\end{array}$ & $\begin{array}{l}\text { Government } \\
\text { J Shipley } \\
\text { (National) }\end{array}$ & Amending & Broadcasting & Low & $\begin{array}{c}\text { Carried over at end } \\
\text { of session and } \\
\text { lapsed }\end{array}$ & Electoral Law \\
\hline 2000 & $\begin{array}{l}\text { Electoral (Public Opinion Polls) } \\
\text { Amendment Bill }^{460}\end{array}$ & $\begin{array}{c}\text { Private Member } \\
\text { W Peters } \\
\text { (NZ First) }\end{array}$ & Amending & $\begin{array}{l}\text { Electioneering and } \\
\text { Finance }\end{array}$ & High & $\begin{array}{l}\text { Defeated on First } \\
\quad \text { Reading }\end{array}$ & No \\
\hline
\end{tabular}

\footnotetext{
${ }^{456}$ Sought to prevent 'party-hopping'

${ }^{457}$ For: Labour, Alliance; Against: National, NZ First, ACT, United, Independent, Donald, Fitzsimons
}

${ }^{458}$ Sought to implement, in part, the recommendations of the Electoral Law Committee in relation to its inquiry into the conduct of the 1996 general election. Included numerous amendments, of a minor and technical nature, to the Electoral Act.

${ }^{459}$ Sought to remove the requirement on the Electoral Commission to 'invite' all broadcasters to make offers of free or discounted broadcasting time for election programmes.

${ }^{460}$ Provided for a 28-day period prior to a general election or a by-election during which it would be an offence to publish the results of a public opinion poll conducted during that period in relation to the general election or by-election.

${ }^{461}$ For: National, Alliance, NZ First, United; Against: Labour, ACT, Green 


\begin{tabular}{|c|c|c|c|c|c|c|c|}
\hline Year & Name & Origin & Effect & $\begin{array}{l}\text { Affected Areas of } \\
\text { Electoral Law }\end{array}$ & Contention & Outcome & Select Committee \\
\hline 2002 & Electoral Options Referenda Bill ${ }^{462}$ & $\begin{array}{c}\text { Private Member } \\
J \text { Shipley } / S \\
\text { Power } \\
\text { (National) }\end{array}$ & Original & Referendum & Moderate & $\begin{array}{l}\text { Defeated on First } \\
\text { Reading }\end{array}$ & No \\
\hline 2002 & $\begin{array}{c}\text { Electoral (Racially-Based } \\
\text { Representation) Referendum Bill }\end{array}$ & $\begin{array}{l}\text { Private Member } \\
\text { Shirley } \\
\text { (ACT) }\end{array}$ & Original & $\begin{array}{c}\text { Maori; } \\
\text { Number of MPs }\end{array}$ & High & $\begin{array}{l}\text { Defeated on } \\
\text { Introduction }\end{array}$ & No \\
\hline 2005 & Electoral (Integrity) Amendment Bill ${ }^{465}$ & $\begin{array}{l}\text { Government } \\
\text { Clark } \\
\text { (Labour) }\end{array}$ & Amending & MP Qualification & High & $\begin{array}{l}\text { Lapsed after referral } \\
\text { to Select Committee }\end{array}$ & Justice \& Electoral \\
\hline 2006 & $\begin{array}{c}\text { Electoral (Reduction in Number of } \\
\text { Members of Parliament) Amendment } \\
\text { Bill }^{466}\end{array}$ & $\begin{array}{l}\text { Private Member } \\
\text { Stewart } \\
\text { (NZ First) }\end{array}$ & Amending & Number of MPs & Moderate & $\begin{array}{c}\text { Defeated on Second } \\
\text { Reading }\end{array}$ & Justice \& Electoral \\
\hline 2008 & Electoral Finance Amendment Bill ${ }^{468}$ & $\begin{array}{c}\text { Private Member } \\
\text { English } \\
\text { (National) }\end{array}$ & Amending & $\begin{array}{l}\text { Electioneering and } \\
\text { Finance }\end{array}$ & $\mathrm{N} / \mathrm{A}$ & Not Debated & $\mathrm{N} / \mathrm{A}$ \\
\hline
\end{tabular}

\footnotetext{
second a binding referendum on what system should be moved to.

${ }^{463}$ For: National, ACT, United; Against: Labour, NZ First, Green

${ }^{464}$ Sought to remove the Maori seats.

${ }^{465}$ Sought to prevent 'party-hopping'.

${ }^{466}$ Proposed a reduction of the number MPs from 120 to 100.

${ }^{467}$ For: NZ First, ACT; Against: Labour, National, Green, Maori Party, United Future, Progressive

${ }^{468}$ Sought to alter the requirement for a home address to be used on authorisation statements under the Electoral Finance Act.
}

${ }^{462}$ Proposed the holding of two referenda on the electoral system: the first an indicative referendum on whether the electoral system should be changed from MMP, and the 


\section{Bibliography}

\section{Primary Sources}

Appendices to the Journals of the House of Representatives. 1927 - 2007

Journals of the House of Representatives. 1927 - 2007

New Zealand Gazette. 1927 - 2007.

New Zealand Parliamentary Debates (NZPD). 1927 - 2007

Royal Commission on the Electoral System: Towards a Better Democracy, Wellington, December 1986

\section{Secondary Sources}

Andrews, J., and Jackman, R. 'Strategic Fools: Electoral Rule Choice Under Extreme Uncertainty.' Electoral Studies, 2005, 24(1), pp. 65-84.

Atkinson, N. Adventures in Democracy: A History of the Vote in New Zealand. University of Otago Press, Dunedin, 2003.

Bassett, M. Coates of Kaipara. Auckland University Press, Auckland, 1995.

Bassett, M. Three Party Politics in New Zealand 1911-1931, Historical Publications, Auckland, 1982.

Bassett, M. \& King, M., Tomorrow Comes the Song - A Life of Peter Fraser. Penguin, Auckland, 2000.

Benoit, K. 'Models of Electoral System Change'. Electoral Studies, 2004, 23(3), pp. 363-89.

Blais, A., and Massicotte, L. 'Electoral Formulas: A Macroscopic Perspective'. European Journal of Political Research, 1997, 32(1), pp. 107-29.

Boix, C. 'Setting the Rules of the Game: The Choice of Electoral Systems in Advanced Democracies'. American Political Science Review, 1999, 93(3), pp. 60924.

Boston, J., Levine, S., McLeay, E., and Roberts, N. (eds.), Electoral and Constitutional Change in New Zealand: An MMP Sourcebook. Dunmore Press, Palmerston North, 1999.

Bowler, S., Donovan, T., and Karp, J. 'Why Politicians Like Electoral Institutions: Self-Interest, Values or Ideology?'. The Journal of Politics, May 2006, 68(2), pp. 434-446. 
Brassington, A. 'The Constitution of New Zealand - Aspects of Change and Development'. New Zealand Law Journal, 4 June 1963, pp. 213-223.

Burrows, J. Statute Law in New Zealand. $3^{\text {rd }}$ ed., LexisNexis, Wellington, 2003.

Caldwell, J. 'Election Manifesto Promises: the Law and Politics'. New Zealand Law Journal, 108, 1989.

Chapman, R., Jackson, K., \& Mitchell, A. New Zealand Politics in Action: The 1960 General Election. Oxford University Press, London, 1962.

Clark, M. (ed.) The Bolger Years. Dunmore Publishing, Wellington, 2008.

Collins, D. 'A Constitutional Conundrum'. New Zealand Law Journal, May 1975, pp. 195-196

Colomer, J. (ed.), Handbook of Electoral System Choice. Palgrave-Macmillan, London, 2004.

Dicey, A. Introduction to the Study of the Law of the Constitution. $8^{\text {th }}$ ed., Liberty Fund, Indianapolis, 1982

Dunleavy, P., and Margetts, H. 'Understanding the Dynamics of Electoral Reform'. International Political Science Review, 1995, 16(1), pp. 9-29.

Edwards, B. Right Out: Labour's Victory '72, the Inside Story. A.H Read, Wellington, 1973.

Gallagher, M., \& Mitchell, P. (eds.) The Politics of Electoral Systems. Oxford University Press, Oxford, 2005.

Geddis, A. Electoral Law in New Zealand: Practice and Policy. LexisNexis, Wellington, 2007.

Grofman, B. Political Gerrymandering and the Courts. Agathon Press, New York, 1990.

Gustafson, B. Constitutional Changes since 1870. Heinemann Educational Books, Auckland, 1969.

Gustafson, B. The First 50 Years: A History of the New Zealand National Party. Reed Methuen, Auckland, 1986.

Gustafson, B. From the Cradle to the Grave: a Biography of Michael Joseph Savage. Reed Methuen, Auckland, 1986.

Gustafson, B. His Way: a Biography of Robert Muldoon. Auckland University Press, Auckland, 2000.

Gustafson, B. Kiwi Keith. Auckland University Press, Auckland, 2007. 
Hawke, G. (ed.) Changing Politics? The Electoral Referendum 1993. The Institute of Policy Studies, Wellington, 1993.

Heard, A. 'Constitutional Conventions and Election Campaigns', Canadian Parliamentary Review, Autumn, 1995.

Herbert, A. The Ayes Have It. Methuen \& Co, London, 1937.

Jackson, K. The New Zealand Legislative Council. University of Otago Press, Dunedin, 1972.

Jackson, K. New Zealand: Politics of Change. Reed Education, Wellington, 1983.

Jackson, W.K. 'Political Leadership and Succession in the New Zealand National Party'. Political Science, 27(1-2), 1975, pp. 1-24.

Jackson, K., \& McRobie, A. New Zealand Adopts Proportional Representation Accident? Design? Evolution? Ashgate Publishing, Aldershot, 1998.

Joseph, P. (ed.) Essays on the New Zealand Constitution. Brookers, Wellington, 1995.

Joseph, P. 'Mrs Kopu's Challenge to MMP', New Zealand Law Journal, December 1997, pp. 413-414.

Joseph, P. Constitutional and Administrative Law in New Zealand. $3^{\text {rd }}$ ed., Thomson Brookers, Wellington, 2007.

Lamare, J., \& Vowles, J. 'Party Interests, Public Opinion and Institutional Preferences: Electoral System Change in New Zealand'. Australian Journal of Political Science, 31(3), 1996, pp. 321-345.

Lijphart, A. Electoral Systems and Party Systems: A Study of Twenty-seven Democracies, 1945-1990. Oxford University Press, Oxford, 1994.

Lipson, L. The Politics of Equality: New Zealand's Adventures in Democracy. University of Chicago Press, Chicago, 1948.

Marshall, G. Constitutional Theory. Clarendon Press, Oxford, 1971.

Marshall, G. Constitutional Conventions: The Rules and Forms of Political Accountability. Oxford University Press, Oxford, 1986.

Marshall, J. (ed.). The Reform of Parliament. New Zealand Institute of Public Administration, Wellington, 1978.

McGee, D. Parliamentary Practice in New Zealand. $3^{\text {nd }}$ ed., Dunmore Press, Wellington, 2005. 
McLeay, E. \& Vowles, J. 'Redefining Constituency Representation: the Roles of New Zealand MPs Under MMP', Regional and Federal Studies, 17(1), pp. 71-95, March 2007.

McRobie, A. New Zealand Electoral Atlas. GP Books, Wellington, 1989.

Miller, R. (ed.) New Zealand Government and Politics. Oxford University Press, Auckland, 2006.

New Zealand Law Journal. Editorial: 'Election Spending', March 2008, p. 41

New Zealand Law Journal. Editorial: 'The Pledge Card', September 2006, p. 281

O'Connor, R. 'Election petitions under the Electoral Act 1956'. New Zealand Law Journal, April 1990, pp. 122-128

Palmer, G. Unbridled Power. $2^{\text {nd }}$ ed., Oxford University Press, Auckland, 1987.

Palmer, G., \& Palmer, M. Bridled Power. $4^{\text {th }}$ ed., Oxford University Press, Auckland, 2004.

Rae, D. The Political Consequences of Electoral Laws. Yale University Press, New Haven, 1967.

Renwick, A. 'Why Did National Promise a Referendum on Electoral Reform in 1990?'. Political Science, 59(1), 2007, pp. 7-22.

Ritchie, B., \& Hoffman, H., 'The Electoral Law of New Zealand, A Brief History'. Towards a Better Democracy: Report of the Royal Commission on the Electoral System, Appendix A, Wellington, 1986.

Robinson, A. 'Parliament in New Zealand', in The Reform of Parliament, J. Marshall (ed.), New Zealand Institute of Public Administration, Wellington, 1978.

Rokkan, S. Citizens, Elections, Parties: Approaches to the Comparative Study of the Processes of Development. McKay, New York, 1970.

Scott, K. The New Zealand Constitution. Oxford University Press, Oxford, 1962.

Sinclair, K. Walter Nash. Auckland University Press, Auckland, 1976.

Sorrenson, K. 'A History of Maori Representation in Parliament'. Towards a Better Democracy: Report of the Royal Commission on the Electoral System, Appendix B, Wellington, 1986.

Tsebelis, G., Nested Games: Rational Choice in Comparative Politics. University of California Press, Los Angeles, 1990.

Vowles, J. 'The Politics of Electoral Reform in New Zealand'. International Political Science Review, 16(1), 1995, pp. 95-115. 
Wallace, J. 'Reflections on Constitutional and Other Issues Concerning our Electoral System: The Past and the Future'. Political Science, 54(1), July 1976, pp. 41-57. 